TATIANA ROBLES SEFERJAN

\title{
LIBERDADE RELIGIOSA E LAICIDADE DO ESTADO NA CONSTITUIÇÃO DE 1988
}

Dissertação apresentada à Banca Examinadora da Faculdade de Direito da Universidade de São Paulo como exigência parcial para a obtenção do título de Mestre em Direito do Estado.

Orientação: Professor Associado Alexandre de Moraes

Área de concentração: Direito do Estado

\author{
UNIVERSIDADE DE SÃO PAULO \\ FACULDADE DE DIREITO \\ SÃO PAULO \\ 2012
}


Banca Examinadora 


\section{RESUMO}

$\mathrm{O}$ debate religioso sob uma perspectiva constitucional envolve dois conceitos fundamentais: a liberdade de religião e a laicidade do Estado. A liberdade de religião está garantida na Constituição de 1988 como um direito fundamental, no artigo $5^{\circ}$, VI. A proteção da liberdade de religião engloba a liberdade de crença, de culto e de organização religiosa. Somente com a consagração destas três vertentes o direito à liberdade religiosa estará plenamente garantido. As garantias constitucionais vão mais além. A Constituição de 1988, em seu artigo 19, I, prevê a existência de uma Separação entre Estado e Igreja. Como consequência deste cenário de proteção, são garantidos pelo nosso ordenamento alguns institutos como a objeção de consciência e assistência religiosa. Apesar da consagração de um Estado Laico, é possível pensar numa forte influência religiosa sobre o Estado brasileiro. Esta influência gera a discussão sobre a relação entre a adoção de uma religião pelo Estado e o respeito à tolerância religiosa e à amplitude da liberdade religiosa. Alguns temas específicos permitem reconhecer a verdadeira vocação do Estado, religioso ou secular. Podem ser citados os seguintes casos: símbolos religiosos em prédios públicos e o seu porte por cidadãos; proibição do aborto; transfusão de sangue em Testemunhas de Jeová; ensino religioso em escolas públicas, dentre outros. Com base nos princípios e nas situações expostas, será possível analisar o caráter da Separação entre Estado e Igreja no Estado brasileiro e sua influência na proteção do direito à liberdade religiosa.

\section{ABSTRACT}

Le débat religieux sur un point de vue constitutionnel repose sur deux concepts: la liberté de religion et la laïcité de l'Etat. La liberté de religion est garantie dans la Constitution de 1988 comme un droit fondamental à l'article 5, VI. La protection de la liberté de religion inclut la liberté de croyance, de culte et de l'organisation religieuse. C'est seulement avec le dévouement de ces trois domaines du droit que la liberté religieuse serait pleinement garantie. Les garanties constitutionnelles d'aller plus loin. La Constitution de 1988, à l'article 19, I, prévoit l'existence d'une séparation entre Eglise et Etat. En raison de scénario de protection, sont garantis par notre cadre constitutionnel certains instituts tels que l'objection de conscience et de l'assistance religieuse. Malgré le dévouement d'un État laïque, c'est possible penser à une forte influence religieuse sur l'État brésilien. Cette influence génère la discussion sur la relation entre l'adoption d'une religion par l'Etat et du respect de la tolérance religieuse et de la liberté religieuse. Certains thèmes spécifiques sont fondamentales par reconnaître la véritable vocation de l'Etat, religieuse ou laïque. Peveunt être cités les cas suivants: symboles religieux dans les édifices publics et leur taille par les citoyens; interdiction de l'avortement; transfusion sanguine chez les Témoins de Jéhovah, l'instruction religieuse dans les écoles publiques, entre autres. Basé sur les principes et dans de telles situations, ce serait possible analyser le caractère de séparation entre Église et État dans l'État brésilien et son influence dans la protection du droit à la liberté religieuse. 


\section{SUMÁRIO}

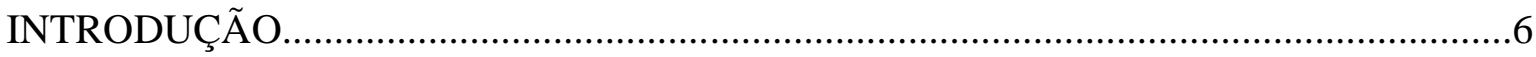

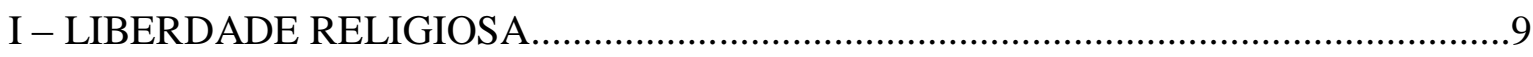

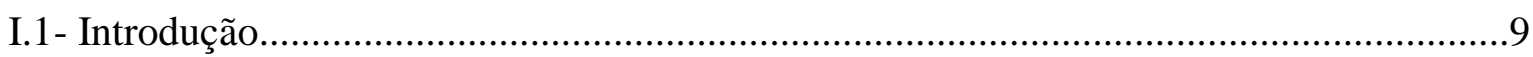

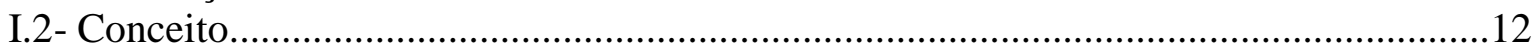

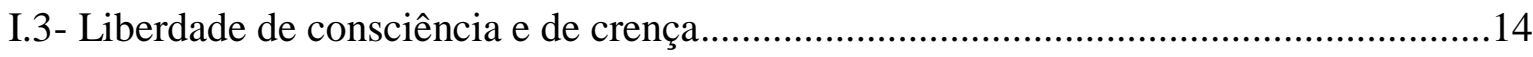

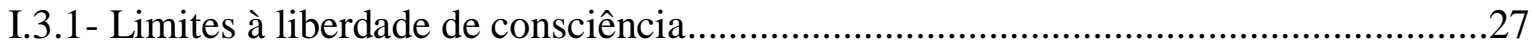

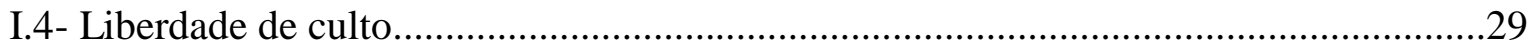

II - RELAÇÕES ESTADO E IGREJA.................................................................40

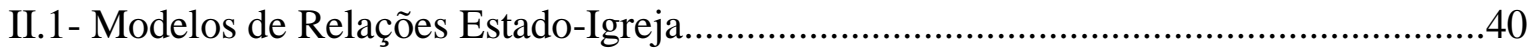

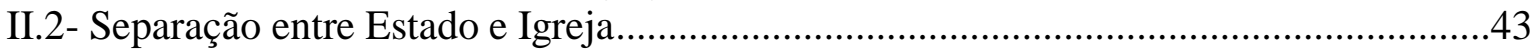

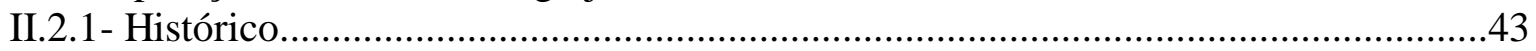

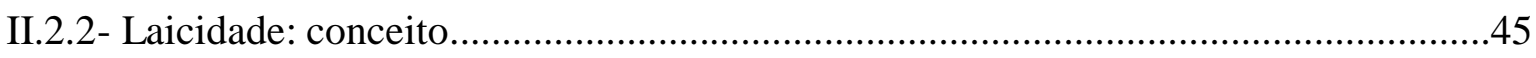

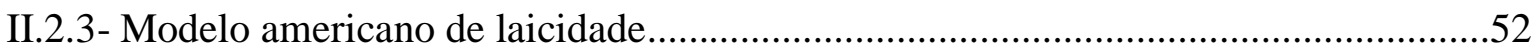

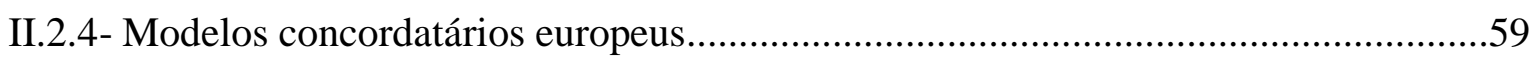

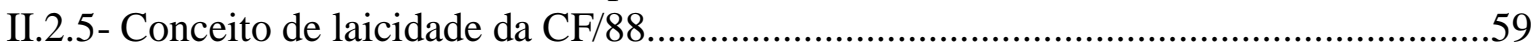

III - REFLEXOS DA LAICIDADE DO ESTADO NO ORDENAMENTO

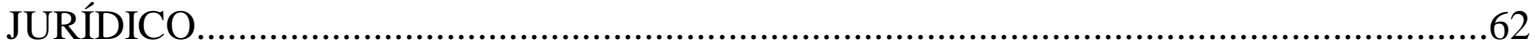

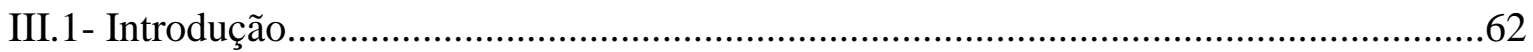

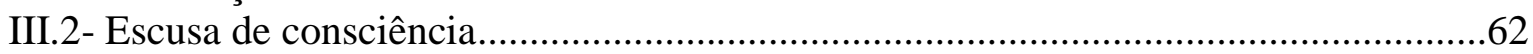

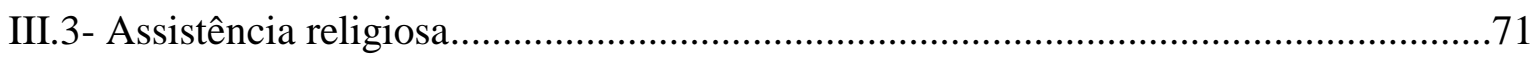

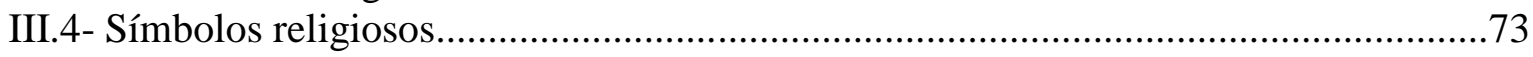

III.4.1. Porte de símbolos religiosos e o véu islâmico.....................................................74

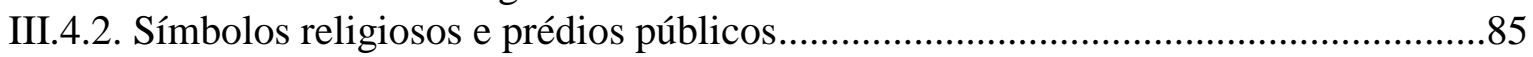

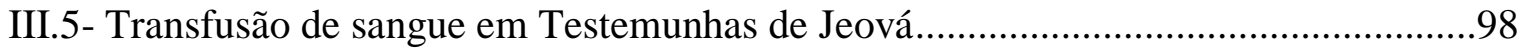

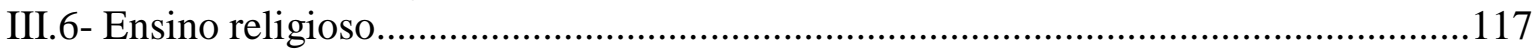

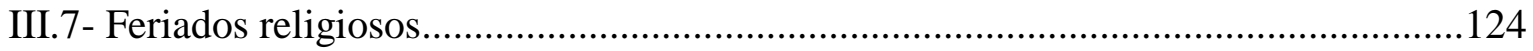

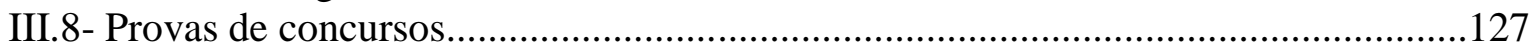

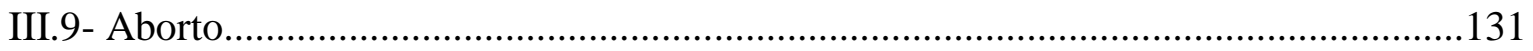

III.10- Cultos religiosos e poder de polícia................................................................... 145

CONCLUSÃO

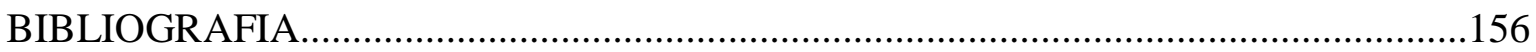




\section{INTRODUÇÃO}

A Constituição Federal de 1988 apresenta um extenso rol de direitos fundamentais, dentre o qual está a liberdade religiosa. Juntamente com a liberdade de religião, garantida em todos os seus aspectos, a Carta Magna consagrou a laicidade do Estado. A liberdade religiosa é um direito que, tradicionalmente, tem sido contemplado pelas Constituições brasileiras, seja sob o ângulo da liberdade de consciência, seja pelo ângulo da liberdade de crença.

A liberdade religiosa pode ser considerada como um aspecto da liberdade de opinião. Num primeiro plano, a liberdade de religião integra-se no âmbito da liberdade de opinião, de modo a significar para o indivíduo a possibilidade de dar ou não a sua adesão a uma religião, a ser escolhida livremente. Essa liberdade não se restringe, todavia, à escolha de uma crença pelo indivíduo. Ela dá origem também a uma prática, isto é, o culto.

Fundamental na garantia da liberdade religiosa está a consagração da laicidade estatal, nos termos do art. 19, I da CF/88. Ao adotar o modelo de separação entre Estado e Igreja, pretendeu o texto constitucional evitar que o Estado causasse quaisquer embaraços à atividade religiosa, seja prejudicando seja beneficiando determinadas religiões.

Com a promulgação da Constituição de 1988, pode-se perceber uma tendência em garantir ampla eficácia aos direitos fundamentais. Vive-se, assim, um período bastante favorável para a afirmação dos mais diversos direitos fundamentais. Ocorre que a tentativa de conferir amplas proteção e efetividade a tais direitos gera, indubitavelmente, alguns problemas. Frequentemente, o exercício da liberdade de crença ou de culto irá chocar-se com outros bens igualmente protegidos pela Constituição. É preciso, portanto, saber como enfrentar tais questões bastante delicadas de modo a não desnaturar a proteção conferida pela Constituição às liberdades religiosas.

O cenário envolvendo a liberdade religiosa torna-se ainda mais complicado, quando se tenta conciliar tal garantia com a neutralidade do Estado, em razão de sua laicidade.

Apesar da tradicional consagração tanto da liberdade religiosa quanto da laicidade do Estado, a história brasileira é profundamente marcada por uma forte influência da Igreja Católica. Assim, parece ser importante a análise de como as garantias constitucionais ligadas à crença e ao culto religioso são enfrentados tanto doutrinária 
quanto jurisprudencialmente.

Muitos dos principais questionamentos envolvendo os limites da liberdade religiosa revelam um possível conflito desta liberdade frente o dever de neutralidade estatal. Surgem questionamentos quanto à possibilidade de o Estado laico coexistir com conceitos e valores religiosos, a exemplo, da discussão sobre símbolos religiosos em prédios públicos, ou mesmo sobre o porte de tais símbolos pelos indivíduos em ambientes públicos. Até que ponto pode o Estado interferir no uso de símbolos religiosos pelos cidadãos? Pode um Estado laico conviver com a existência de símbolos claramente religiosos? O reconhecimento de influências religiosas sobre o Estado impediria o seu reconhecimento como um Estado laico?

No mesmo sentido, poderia o Estado obrigar que Testemunhas de Jeová recebessem transfusões de sangue sob o intuito de proteção do direito à vida? A proibição do aborto denuncia uma concepção religiosa do Estado sobre o início da vida? A quais limites estão submetidos os cultos religiosos? Em que termos pode ser cumprida a disposição constitucional sobre o ensino religioso?

Para tentar responder a estes questionamentos, será estudado no primeiro capítulo como a Constituição de 1988, com referências a doutrina nacional e estrangeira, consagrou a liberdade religiosa, em todos os seus aspectos, quais sejam, a liberdade de crença, de culto e de organização religiosa.

Após, serão brevemente expostos os modelos de relação entre Estado e Igreja (confusão, união e separação), para que seja possível entender em que termos está estabelecido regime de separação entre Estado e Igreja vigente na ordem constitucional atual.

Ultrapassada a fase de análises conceituais sobre a liberdade religiosa e o Estado Laico, passar-se-á a enfrentar isoladamente alguns dos principais conflitos envolvendo os conceitos estudados, fazendo uma análise crítica da situação, com o intuito de propor uma solução para a situação exposta.

Nesta fase serão analisados os seguintes temas: escusa de consciência; assistência religiosa; porte de símbolos religiosos; símbolos religiosos em prédios públicos; transfusão de sangue em Testemunhas de Jeová; feriados religiosos; ensino religioso em escolas públicas; limites administrativos aos cultos religiosos; realização de provas de concursos em dias sagrados para determinadas religiões; proibição do aborto.

O enfrentamento de cada um desses temas será dado sob uma dupla 
perspectiva. Por um lado, será exposta a opinião da doutrina nacional e estrangeira e, por outro, será verificada a posição dos Tribunais pátrios e estrangeiros na solução do problema em exame.

Quanto à metodologia, para a análise de como a liberdade religiosa e a relação entre Estado e Igreja desenvolveram-se na história de nosso constitucionalismo, será utilizado o método histórico-sistemático. O método sistemático será fundamental para situar a liberdade religiosa e a laicidde do Estado na Constituição Federal de 1988.

O método dedutivo será empregado para o estudo das diversas acepções que podem ser conferidas à liberdade religiosa. Por fim, o método dialético será essencial no estudo dos diversos desdobramentos práticos da liberdade religiosa. Com o emprego de tal método, poderá ser feita a contraposição entre as soluções propostas, bem como entre os valores que serão apresentados em conflito. 


\section{I - LIBERDADE RELIGIOSA}

\section{I.1- Introdução}

Preliminarmente ao estudo do direito à liberdade religiosa no ordenamento constitucional atual, é interessante fazer uma breve introdução do quadro religioso no Brasil.

Antonio Gouvea Mendonça ${ }^{1}$ discorre de maneira bastante sucinta sobre a evolução das religiões no Brasil. No século XIX, duas eram as principais religiões presentes: o catolicismo e o protestantismo. Obviamente que estas não eram as únicas religiões presentes, tendo surgido diversas outras que ganharam relevância, como é o caso do positivismo.

Como principal característica do positivismo surge a fórmula "o amor por princípio, a ordem por base, o progresso por fim."2 Sua importância foi de tal maneira relevante que sua fórmula moral acabou inscrita na bandeira republicana.

Na segunda metade do século XIX, advindo da França surgiu o espiritismo, que teve larga aceitação entre as elites liberais, em razão de suas concepções racionalistas e evolucionistas. Os cultos étnicos, indígenas ou africanos, não tiveram grande representatividade durante o século XIX, fazendo, assim, com que a Igreja Católica Romana fosse praticamente hegemônica.

Apesar de a Igreja Católica ser a religião de maior prestígio, merecendo, inclusive, proteção constitucional, ela teve que aprender a conviver com outras religiões, principalmente, com a protestante, que mais englobava fiéis. A existência de várias religiões fez com que nascesse a ideia da tolerância religiosa:

Duas circunstâncias históricas levaram, tanto leigos como clérigos católicos, a consagrar o princípio da tolerância na Constituição: de um lado, compromissos políticos assumidos com a Inglaterra por ocasião da transferência da Corte Portuguesa para o Brasil, em 1808, e consagrados pelo Tratado de Comércio e Navegação e, de outro, a opção por colonos europeus em substituição da mão-de-obra escrava já prevista. ${ }^{3}$

\footnotetext{
${ }^{1}$ MENDONÇA, Antonio Gouvêa. República e pluralidade religiosa no Brasil. Revista USP, São Paulo, v. 59, 2003, p. 146-162.

${ }^{2}$ MENDONÇA, Op. cit., p. 146.

${ }^{3}$ MENDONÇA, Op. cit., p. 147.
} 
$\mathrm{O}$ primeiro desafio enfrentado pelo Governo brasileiro, no que tange à tolerância foi com os jesuítas, a partir da proclamação da liberdade indígena por Pombal (1750).

Muitos foram os fatores que acabaram limitando o poder hegemônico da Igreja Católica. O protestantismo como religião independente chega ao Brasil dois anos após a independência. Inicialmente, surge o chamado protestantismo de imigração ou de colonização, com a chegada de colonos alemães e suíços ao País. Tal vertente do protestantismo não representou grandes mudanças na política brasileira

O mesmo, contudo, não pode ser dito do protestantismo de missão ou de conversão, trazido pelas missões norte-americanas, com o claro intuito de ganhar novos adeptos à sua religião.

Marco significativo, no campo religioso, é a separação entre Estado e Igreja, em 1890, ocorrida logo após a proclamação da República. Abriu-se, dessa maneira, espaço para o pluralismo religioso hoje vigente no Brasil.

A despeito de a Igreja Católica ter deixado de ser a religião oficial do Estado, ela continuou sendo a religião dominante na cultura brasileira. No século XX, no entanto, várias são as religiões que convivem com a Católica. Vejamos as principais.

\section{Protestantismo}

O protestantismo conta com várias ramificações. O termo evangélico tem sido usado como substituto de protestante em quase todas as áreas, exceto na acadêmica. A palavra evangélico tem origem na expressão inglesa evangelical. Atualmente, pode-se dizer que no Brasil todo protestante é evangélico, mas nem todo evangélico é evangelical, no sentido original da palavra.

A diversidade de cultos protestantes faz parte da própria essência do protestantismo que permite a livre interpretação da Bíblia pelos cristãos. Dessa forma, a Bíblia é a entidade máxima e não a Igreja, enquanto instituição.

$\mathrm{Na}$ evolução da Igreja Protestante, num primeiro momento, surgem os evangélicos históricos ou tradicionais, chamados protestantes, que chegaram ao Brasil no período final do Império. A partir de 1910, surgem os pentecostais propriamente ditos ou clássicos, tais como a Assembleia de Deus e a Congregação Cristã de Deus. Na década de 50, aparecem os neopentecostais. 
Na década de 60, o combate ao desenvolvimentismo e o apoio aos pobres promoveu uma aproximação inédita entre católicos e protestantes, o que terminou com o golpe militar. Os católicos tomaram uma posição combativa à repressão militar, enquanto que os liberais protestantes perderam força e não se pronunciaram no cenário político.

A Igreja Católica também contribuiu para a separação com o protestantismo ao editar diversos documentos asseverando que a união do cristianismo somente poderia dar-se por meio de Roma.

A denominação evangelical conduz a uma ideia de fundamentalismo, de modo que a vertente evangélica do protestantismo brasileiro prega uma forte separação da Igreja Católica. Nos anos 50, com a explosão industrial em São Paulo, surge a vertente pentecostal do protestantismo que rompe tanto com o intelectualismo quanto com a noção autossuficiente e individualista dos evangélicos tradicionais.

\section{Religiões não-cristãs}

Até o censo de 2000, pode-se perceber um aumento significativo na porcentagem da população que declara não ter religião. O candomblé e a umbanda são as religiões brasileiras mais transparentes, apesar de contarem com apenas $1 \%$ de adeptos.

Como se vê a aceitação, que ultrapassa a tolerância, de cultos africanos no Brasil só se deu a partir do fim da Primeira República e ganha espaço ou liberdade plena já no fim dos anos 50. Antes disso, apesar da liberdade de culto estabelecida pela Constituição Republicana, os cultos africanos eram identificados como feitiçaria e enquadrados no crime de prática ilegal da medicina, daí se esconderem sob a rubrica de tendas espíritas. $^{4}$

Neste ponto, as religiões afro-brasileiras aproximam-se das neopentecostais, pois se valem do traço mágico presente na cultura brasileira, de tal modo que o ritual tornase mais importante que a doutrina e, portanto, que a ética.

Há quem vislumbre a criação de uma religião brasileira relativamente uniforme e baseada em rituais semelhantes, com a superação, inclusive de preconceitos que lhes eram comuns.

Tratando-se de religiões não-cristãs não podemos nos esquecer da imigração ocorrida durante a República de povos não-cristãos, como japoneses e árabes. Há que se

\footnotetext{
${ }^{4}$ MENDONÇA, Op. cit., p. 161.
} 
fazer uma nota também acerca da imigração de povos cristãos, como os armênios. Surgem, assim, no Brasil o budismo, o islamismo e o judaísmo.

\section{I.2- Conceito}

A liberdade de crença e de culto, desdobramentos da liberdade religiosa, a quem Schimitt denomina inviolabilidade de consciência livre, caracteriza-se pelo "direito que tem o homem livre de adorar seu deus, de acordo com a sua crença e o seu culto."

O movimento enciclopedista, juntamente com as revoluções da América e da França, introduziu as liberdades de crença e de culto. A Declaração Francesa de 1789, em seu art. 10, dispunha que: "ninguém deve ser inquietado por suas opiniões mesmo religiosas, desde que sua manifestação não perturbe a ordem pública estabelecida pela lei."

No Brasil Colônia, os portugueses empenhavam-se para que se mantivesse a hegemonia da Igreja Católica, de tal modo que predominava o preconceito religioso. Os portugueses consideravam fator de igualdade não tanto a raça da pessoa, mas sim a religião que professava. Assim, o não católico era visto como um verdadeiro adversário político que poderia enfraquecer a estrutura colonial. ${ }^{7}$

A Constituição de 1824 protegia integralmente a liberdade de crença, enquanto que a liberdade de culto era plena apenas para os católicos, pois às outras religiões somente era permitido o culto doméstico. ${ }^{8}$

Regeu no Império, portanto, a União entre Igreja e Estado, de modo que as religiões diferentes da Católica ficavam bastante enfraquecidas, pois não podiam se estabelecer oficialmente. ${ }^{9}$

Com a República, houve o reconhecimento de ampla liberdade religiosa, separando, assim, o Estado da Igreja. Proibiu-se, assim, qualquer subvenção à Igreja, secularizou-se o casamento, os cemitérios e o ensino. ${ }^{10}$

Rui Barbosa teve um papel fundamental na separação entre a Igreja e o Estado e também na promoção da liberdade religiosa. O sistema

\footnotetext{
${ }^{5}$ FERREIRA, Pinto. Curso de direito constitucional. 12 ed. São Paulo: Saraiva, 2002, p. 102.

${ }^{6}$ FERREIRA, P., Op. cit., p. 102.

${ }^{7}$ SORIANO, Aldir Guedes. Liberdade religiosa no direito constitucional e internacional. São Paulo: Juarez de Oliveira, 2002, p. 67-8.

${ }^{8}$ FERREIRA, P., Op. cit., p. 103

${ }^{9}$ SORIANO, A., Op. cit., p. 72

${ }^{10}$ FERREIRA, P., Op. cit., p. 103.
} 
republicano emergente não mais podia conviver com as restrições à liberdade religiosa, especialmente no que se referia ao culto religioso. Nenhuma forma de intolerância se coadunava com o novo ideal republicano. A liberdade de pensamento ou de consciência era de pouca valia, quando se restringia à exteriorização dessas faculdades. ${ }^{11}$

A Constituição de 1934 trouxe uma diferenciação entre liberdade de crença e de culto, mas abrandou as disposições atinentes ao Estado laico, assim como a Carta de 1937.

A Constituição de 1946 intensificou os princípios da Constituição de 1934, dando ênfase à assistência às Forças Armadas e à secularização dos cemitérios. Restou amplamente assegurada a liberdade de crença e de culto, com a permissão do livre exercício de culto a todas as pessoas, assim como a liberdade de convicção religiosa, filosófica e política

Manteve-se na mesma linha que a Constituição de 1946, a de 1967. Admitiu a escusa de consciência, segundo a qual, por motivos de convicção religiosa, filosófica ou política, ninguém, poderia ser privado dos seus direitos salvo se a invocasse para se eximir de obrigação legal imposta a todos. Foi prevista também à assistência religiosa a ser prestada às Forças Armadas e auxiliares e também, quando solicitada, nos estabelecimentos de internação coletiva. ${ }^{12}$

Com a consagração da ampla liberdade religiosa, pela Constituição de 1988, a liberdade religiosa pode ser considerada como um aspecto da liberdade de opinião. Num primeiro plano, a liberdade de religião integra-se no âmbito da liberdade de opinião, de modo a significar para o indivíduo a possibilidade de dar ou não a sua adesão a uma religião, a ser escolhida livremente. Essa liberdade não se restringe, todavia, à escolha de uma crença pelo indivíduo. Ela dá origem também a uma prática, isto é, o culto.

Destarte, apesar de a liberdade de religião ser uma modalidade da liberdade de opinião, ela vai além da mera expressão de um pensamento. A liberdade de religião somente será inteiramente consagrada se as igrejas tiverem total liberdade para professar seus cultos. Dessa liberdade de culto decorre o direito de as igrejas organizarem-se livremente. Neste ponto, surge o problema da relação entre Estado e Igreja. ${ }^{13}$

\footnotetext{
${ }^{11}$ SORIANO, A., 2002, p. 73.

${ }^{12}$ FERREIRA, P., 2002, p. 103-4.

${ }^{13}$ ROBERT, Jacques. Droits de I'homme et libertés fondamentales. 5 ed. Paris: Montchrestein, 1993, p. 508.
} 
“A abrangência do preceito constitucional é ampla, pois sendo a religião o complexo de princípios que dirigem os pensamentos, ações e adoração do homem para com Deus, acaba por compreender a crença, o dogma, a moral, a liturgia e o culto." 14

Podemos perceber, então, que a liberdade religiosa tem três aspectos: liberdade de crença; liberdade de culto e; liberdade de organização religiosa. Vejamos:

Liberdade de consciência consiste essencialmente na liberdade de opção, de convicções e de valores, ou seja, a faculdade de escolher os próprios padrões de valoração ética ou moral da conduta própria e alheia. A liberdade de religião é a liberdade de adoptar ou não uma religião, de escolher uma determinada religião, de fazer proselitismo num sentido ou noutro, de não ser prejudicado por qualquer posição ou atitude religiosa ou anti-religiosa. A liberdade de culto compreende o direito individual ou colectivo de praticar actos externos de veneração próprios de uma determinada religião. As duas primeiras liberdades (a liberdade de consciência e de religião) integram a esfera nuclear dos direitos pessoais, não podendo ser sacrificadas nem sequer em caso de estado de sítio. ${ }^{15}$

Considerando que todos esses aspectos estão protegidos pela Constituição atual, analisemos cada um deles. ${ }^{16}$

\section{I.3- Liberdade de consciência e de crença}

O primeiro desdobramento da liberdade religiosa é a liberdade de consciência, que representa o núcleo e o nascimento da própria liberdade religiosa. Afinal, será ela a garantir a livre expressão do pensamento, em matéria religiosa e sem ele, todos os outros aspectos não poderiam sequer existir.

A Declaração Universal dos Direitos do Homem de 1948 preceitua em seu art. XVIII:

\footnotetext{
${ }^{14}$ MORAES, Alexandre de. Direitos humanos fundamentais - teoria geral - comentários aos arts. $\mathbf{1}^{\circ}$ a $5^{\circ}$ da Constituição da República Federativa do Brasil. 9 ed. São Paulo: Atlas, 2011, p. 127.

${ }^{15}$ CANOtilho, J. J. Gomes; MOREIRA, Vital. Constituição da República Portuguesa Anotada. 3 ed. Coimbra: Coimbra Editora, 1993, p. 212-3. No mesmo sentido, está Pinto Ferreira [Comentários à Constituição Brasileira de 1988. 2 ed. São Paulo: Saraiva, 1989, Vol. I, p. 69-70]: “A liberdade de consciência é inviolável, tendo sido garantida expressamente na Constituição. O sistema democrático e jurídico-constitucional da liberdade de pensamento é básico e desdobra-se das seguintes maneiras: a) liberdade de consciência, compreendendo a liberdade de crença (direito de professar qualquer religião ou de ser ateu) e a liberdade de opinião ou o direito de possuir convicções próprias em matéria política ou filosófica; b) liberdade de exteriorização ou de manifestação do pensamento, abrangendo a liberdade de culto (organização de movimentos religiosos, proselitismo, edificação da igreja e templo) e, além disso, a liberdade de palavra, imprensa, cátedra, ou aprendizagem científica, artística, literária.”

${ }^{16}$ SILVA, José Afonso da. Curso de direito constitucional positivo. 33 ed. São Paulo: Malheiros, 2010, p. 248.
} 
Toda pessoa tem direito à liberdade de pensamento, de consciência e de religião; este direito implica a liberdade de mudar de religião ou de convicção, bem como a liberdade de manifestar sua religião ou convicção, só ou em comum, quer em público, quer privadamente, pelo ensino, pela prática, pelo culto e pelo cumprimento de ritos. ${ }^{17}$

A liberdade de consciência e de crença está consagrada no art. $5^{\circ}, \mathrm{VI}^{18}$ da Constituição Federal de 1988, podendo, portanto, ser considerada um direito individual fundamental. ${ }^{19}$ A liberdade de consciência é tradicional na história do constitucionalismo brasileiro, já que todas as nossas Constituições consagraram-na ${ }^{20}$.

Ao se falar em liberdade de consciência deve-se lembrar que a consciência é sempre livre, fazendo com que tal liberdade não precise de proteção constitucional. O direito não deve-se preocupar com o que é interno ao homem, pois o mero pensamento não tem qualquer relevância no mundo jurídico. O que deve o constituinte proteger é a projeção da consciência no mundo externo. Assim, a crença somente deveria ser objeto de preocupação, quando externalizada através de um culto. O que realmente importaria seria a prática da consciência e da crença. ${ }^{21}$

A reserva pessoal das convicções religiosas é um dos direitos inseridos na liberdade religiosa. Nenhuma autoridade pública ou privada pode obrigar que qualquer indivíduo revele suas crenças. As convicções e as práticas religiosas são questões de foro íntimo, indiferentes ao estatuto social, profissional ou político dos cidadãos. ${ }^{22}$

A assertiva de que a liberdade religiosa faz parte da esfera íntima dos indivíduos parece despida de questionamentos se considerada de maneira teórica. A realidade de Estados que enfrentam conflitos sociais baseados em questões religiosas torna qualquer afirmação categórica sobre a liberdade religiosa facilmente questionável.

Tanto é assim que a Corte Europeia de Direitos Humanos foi chamada a decidir acerca da possibilidade de os cidadãos turcos serem obrigados a informar em seus documentos de identidade a sua religião. Ainda que a Corte tenha entendido que tal

\footnotetext{
${ }^{17}$ FERREIRA, Pinto. Comentários à Constituição Brasileira de 1988. 2 ed. São Paulo: Saraiva, 1989, Vol. I, p. 70.

${ }^{18}$ É inviolável a liberdade de consciência e de crença, sendo assegurado o livre exercício dos cultos religiosos e garantida, na forma da lei, a proteção aos locais de culto e suas liturgias.

${ }^{19}$ FERRAZ, Anna Cândida da Cunha. O ensino religioso nas escolas públicas: exegese do $\S 1^{\circ}$ do art. 210 da CF. Cadernos de Direito Constitucional e Ciência Política, São Paulo. v.5. n.20. p.19-47. jul./set. 1997, p. 28.

${ }^{20}$ ROBERT, 1993, p. 106-7.

${ }^{21}$ CRETELLA JR., José. Comentários à Constituição Brasileira de 1988. 3 ed. Rio de Janeiro: Forense, 1997, Vol. I, p. 216

${ }^{22}$ CANOTILHO; MOREIRA, 1993, p. 213.
} 
obrigatoriedade viola a Convenção Europeia de Direitos Humanos, o mero surgimento da demanda mostra a falta de clareza sobre a extensão da proteção à liberdade de religião. ${ }^{23}$

No decorrer deste estudo, será possível demonstrar o quão complexas são as questões que envolvem a matéria religiosa e como têm sido as soluções alcançadas pelos ordenamentos jurídicos.

Tem a liberdade religiosa sido considerada por parte da doutrina uma liberdade secundária, pois derivada da liberdade de opinião. ${ }^{24}$ Assim sendo, há quem entenda $^{25}$ que, num primeiro plano, essa liberdade não poderia ser controlada, pois estaria no âmbito da consciência. Somente na medida em que fosse exteriorizada a crença deveria ser tutelada, cabendo ao Estado proteger tais manifestações através de uma conduta tanto negativa quanto positiva.

Celso Ribeiro Bastos ${ }^{26}$ discorda da posição segundo a qual o pensamento não deve merecer proteção jurídica, já que se realizaria no foro íntimo do indivíduo. Entende o autor que a vida espiritual não se desenvolve alheia à sociedade, pelo contrário, ela depende de condições sociais, econômicas, históricas e culturais. Além do que, o pensamento não se circunscreve ao domínio íntimo, mas tende a se exteriorizar, já que tem uma vocação ao proselitismo. Dessa maneira, a liberdade de opinião, quando faz referência a aspectos religiosos e morais receberia o nome de liberdade de consciência.

A doutrina ${ }^{27}$ costuma estabelecer uma diferença entre crença e consciência. A crença seria um estado particular da alma humana, um aspecto interior do indivíduo. A religião referir-se-ia, então, ao culto e à crença. A consciência, por sua vez, diria respeito ao direito de acreditar no que o indivíduo desejar, bem como de não acreditar em religião nenhuma. Mas a liberdade de consciência não implica a liberdade de culto, que é outro aspecto da liberdade religiosa.

Há quem entenda ${ }^{28}$ que a liberdade de consciência não precisa estar ligada necessariamente a um sistema religioso, mas poderia apenas referir-se à adesão a valores

\footnotetext{
${ }^{23}$ CORTE EUROPEIA DE DIREITOS HUMANOS - Sinan Isik v. Turquia - Processo 21924/05 - Julgado em 02/02/2010 - Disponível em: http://www.echr.coe.int/NR/rdonlyres/E0941C75-D511-487B-A99155A7074B5E59/0/FICHES_Liberté_religion_FR.pdf - Acessado em 11/05/2011.

${ }^{24}$ CRETELLA JR, José. Liberdades Públicas. 4 ed, São Paulo: José Bushatsky, 1974, p. 101

${ }^{25}$ FERRAZ, 1997, pp. 30-31.

${ }^{26}$ BASTOS, Celso Ribeiro. Direito de recusa de pacientes submetidos a tratamento terapêutico às transfusões de sangue, por razões científicas e convicções religiosas. Revista dos Tribunais, São Paulo, v.90, n.787, jul. 2001, p. 497.

${ }^{27}$ ROBERT, 1993, pp. 103-104.

${ }^{28}$ BASTOS, 2001.
} 
morais e espirituais. Um exemplo seriam os movimentos pacifistas, que pregam a paz e a proscrição da guerra, mas não se filiam a uma fé religiosa.

Além do que, a liberdade de consciência envolve não só uma proteção a quem tem uma crença, mas também aos ateus e agnósticos. De acordo com Celso Ribeiro de Bastos $^{29}$, a tutela jurídica de quem não professa nenhuma religião ocorre por meio da liberdade de consciência.

José Afonso da Silva ${ }^{30}$, por sua vez, entende que a liberdade de crença envolve a liberdade de aderir a uma religião, de mudar de religião, ou ainda de não aderir à religião nenhuma, de ser ateu e de professar o agnosticismo. Contudo, a liberdade de crença "não compreende a liberdade de embaraçar o livre exercício de qualquer religião, de qualquer crença, pois aqui também a liberdade de alguém vai até onde não prejudique a liberdade dos outros."

A liberdade de consciência e a de crença exteriorizar-se-iam na medida em que os indivíduos manifestassem sua escolha por determinada religião, não apenas expressando um pensamento, mas também se esforçando por conquistar novos adeptos à sua crença. Seria, assim, o caráter social de tais manifestações que determinaria a sua proteção pelo ordenamento jurídico, tanto para garanti-las quanto para impedir que elas ocorram de modo prejudicial à sociedade. ${ }^{31}$

Afirmar que a liberdade de consciência é garantida por uma Constituição significa que o Estado deve, ele mesmo, respeitar tal liberdade, bem como agir de maneira a evitar que a liberdade de consciência seja violada por qualquer outro agente. Haveria, destarte, um respeito à liberdade de consciência a partir do momento em que toda conduta que discrimine ou inquiete alguém em razão de sua crença seja reprimida. ${ }^{32}$

Nesse sentido, pode-se falar que “[...] a liberdade de consciência está acima do poder social, é a liberdade do pensamento moral, o sentimento intimo, a crença, o culto interior que não pode ser constrangido." 33

Ademais, a verdadeira liberdade garante a proteção a crenças de qualquer natureza, inclusive a não confessional. A liberdade religiosa envolve o direito não só de ter uma crença, mas também a de não ter crença alguma. O Estado, porém, deve ter a

\footnotetext{
${ }^{29}$ BASTOS, Celso Ribeiro. Curso de direito constitucional. 22 ed. São Paulo: Malheiros, 2010, p. 300.

${ }^{30}$ SILVA, 2010, p. 249.

31 FERREIRA FILHO, Manoel Gonçalves. Curso de direito constitucional. 29 ed, São Paulo: Saraiva, 2002, p. 290.

32 ROBERT, 1993, pp.517-518.

${ }^{33}$ BUENO, José Antonio Pimenta. Direito Público Brazileiro. Rio de Janeiro, Typographia Imp. E Const. De J. Villeneuve e C., 1857, p. 397.
} 
preocupação de impedir a disseminação de opiniões que sejam contrárias aos fundamentos do próprio Estado. ${ }^{34}$

Essa preocupação governamental de proteger os fundamentos do próprio Estado tanto pode ser vista como uma forma de manter a unidade nacional e o respeito à ordem pública, quanto um disfarce para a perseguição de religiões que desagradem à maioria da sociedade sem com isso causar verdadeiros riscos aos direitos fundamentais alheios.

Fica a pergunta. Até que ponto pode o Estado se valer de mecanismos discriminatórios a algumas religiões para manter a ordem constitucional e garantir o respeito ao sistema de proteção dos direitos fundamentais?

Voltando à explanação, o ateísmo, assim, encontra-se igualmente protegido, contudo, para alguns autores tal proteção estaria sob o manto da liberdade de consciência e não da liberdade de religião. ${ }^{35}$

A liberdade de consciência seria, portanto, um caso específico de liberdade do pensamento. A liberdade é especificada pelo objeto diferenciado das opiniões ${ }^{36}$

A possibilidade de expressão da opinião torna a liberdade real, afinal uma liberdade que não se exprime é ilusória. Igualmente fundamental à essência da liberdade é a sua dimensão coletiva. A pessoa não deve ser vista como um indivíduo solitário, mas sim como uma pessoa que somente se realiza em comunidade. A opinião livre é essencial ao ato de fé, mas sua realização somente será completa se for expressada coletivamente. ${ }^{37}$

A liberdade religiosa é um direito de primeira geração, sendo considerado, portanto, uma prerrogativa individual a ser oposta ao Estado. Mas isso não impede que o Estado tenha obrigações positivas. Além de o Estado ter uma obrigação negativa, ele deve proteger o direito à liberdade religiosa contra eventuais violações praticadas quer por particulares quer por autoridades públicas.

Nesta dicotomia entre a liberdade positiva e negativa, a Constituição Espanhola prevê, em seu artigo 16.2, a disposição de que ninguém será obrigado a declarar sua religião, ideologia e crença.

\footnotetext{
${ }^{34}$ FERREIRA, P., 1989, Vol. I, p. 71.

35 MACHADO, Jónatas Eduardo Mendes. Liberdade religiosa numa comunidade constitucional inclusiva: dos direitos da verdade aos direitos dos cidadãos. Coimbra: Coimbra Editora, 1996, p. 222.

${ }^{36}$ DÓRIA, A de Sampaio. Os direitos do homem. 2 ed. São Paulo: Companhia Editora Nacional, 1942, pp. 597-8.

${ }^{37}$ LANARES, Pierre. Liberte religieuse dans les conventions internationales et dans le droit public general; these presentee a l'universite. Roanne: Horvath, 1964, p. 25.
} 
Contudo, entre o aspecto positivo e o negativo da liberdade religiosa, há um ponto de intersecção na liberdade crítico-religiosa. Tal ocorre, pois não se supõe a existência nem de uma fé concreta nem de sua ausência. Ela pressupõe a convivência com o problema religioso. ${ }^{38}$

O direito à liberdade religiosa, em sua essência, trata-se de um direito composto, afinal pode ser desdobrado em quatro vertentes. Nos termos do art. 18 da Declaração Universal dos Direitos do Homem, são elas: liberdade de consciência, de crença, de culto e de organização religiosa. ${ }^{39}$

A liberdade religiosa tem, portanto, um aspecto individual e social. A crença, por si só, poderia ser um fato individual caso fosse mantida apenas em âmbito particular, no foro da consciência. A partir do momento, contudo, em que as pessoas expressam a sua crença religiosa o fenômeno torna-se um fato coletivo. O fato social está presente na publicação, na reunião, na pregação, na oração em comunidade, enfim, em todo comportamento que estabeleça relações baseadas na crença religiosa. Dessa maneira, somente o fato coletivo interessa ao Estado. ${ }^{40}$

Neste sentido, pronuncia-se Rámon Soriano ${ }^{41}$ : 1) do ponto de vista da titularidade e do exercício, é uma liberdade ao mesmo tempo individual e coletiva; 2) da perspectiva de sua assunção pelo sujeito, é uma liberdade que manifesta uma dimensão positiva, negativa e crítico-religiosa; 3) do ângulo da natureza, é uma liberdade específica e diferenciada da liberdade de pensamento e crença.

$\mathrm{Na}$ liberdade religiosa, é significativa a sua dimensão coletiva, que se manifesta juridicamente na constituição de confissões religiosas e socialmente na exteriorização do culto religioso. A liberdade religiosa é uma liberdade individual e coletiva, cujo sujeito tanto pode ser a pessoa em concreto como grupos religiosos. Ela tem uma dupla titularidade tanto com relação aos sujeitos como quanto ao exercício.

Apresentam-se como titulares do direito à liberdade religiosa os indivíduos, sejam eles nacionais ou estrangeiros, e a comunidade. No que tange à titularidade surge uma interessante discussão acerca dos menores de idade. No desempenho de sua capacidade de exercício, o menor não seria sujeito a outras limitações para exercitar o seu direito que aquelas estabelecidas ex lege ou derivadas do grau de maturidade alcançado

\footnotetext{
${ }^{38}$ SORIANO, Rámon. Las libertades públicas. Madrid: Tecnos, 1990, p. 64.

${ }^{39}$ SORIANO, A, 2002, pp. 6-10.

${ }^{40}$ DÓRIA, 1942, pp. 598-9.

${ }^{41}$ SORIANO, R., 1990, p. 63.
} 
para o efeito de assumir determinadas crenças religiosas e, em seu caso, praticá-las conforme os mandamentos religiosos ou preceitos morais desta concreta fé.

Deveria haver uma cooperação entre a vontade dos pais e tutores e do menor. Ao mesmo tempo em que deve ser permitido ao menor exercer a sua liberdade de crença, cabem aos pais propiciar que o menor a exerça da maneira mais adequada ao desenvolvimento. Em caso de conflito, uma vez constatada a falta de cooperação dos responsáveis, deverá ser privilegiado o interesse do menor. ${ }^{42}$

Nenhuma afirmação sobre a liberdade religiosa chega a ser tão cheia de dúvidas quanto essa. $\mathrm{O}$ exercício da liberdade religiosa pelo menor gera seriíssimos problemas quando envolvem a tomada de decisões que podem levar à morte do praticante da religião, como é o caso da transfusão de sangue em Testemunhas de Jeová. Quais parâmetros devem ser empregados para respeitar a vontade do menor ou dos pais? Analisemos mais adiante.

Tratando do caráter objetivo e subjetivo da liberdade religiosa:

Como princípio objetivo, [a liberdade religiosa] demandará dos poderes públicos uma neutralidade (ideológica e) religiosa somente atendida se os poderes públicos renunciarem a toda forma de doutrinação e, com ela, a valorações pró ou contra o universo religioso presente na sociedade; dito em outras palavras, fora as restrições das manifestações em razão da ordem pública que constitucionalmente as limita, isto é, a reserva de que a posteriori se evidencie uma quebra da ordem pública constitucional mediante práticas cultuais, $a b$ initio, não se poderia fechar o espaço constitucional a quaisquer credos religiosos. ${ }^{43}$

Na concepção subjetiva, o Estado deve garantir a imunidade de coação, uma vez que a autodeterminação religiosa impede o Estado de impor, compartilhar ou repudiar determinada confissão religiosa. Seria, portanto, uma proteção específica ao cidadão. ${ }^{44}$

É importante lembrar que a liberdade religiosa surgiu, inicialmente, como resultado de simples armistícios ou tratados de paz entre duas religiões interessadas em cessar um conflito. Na verdade, não havia uma convivência plena entre as religiões, mas sim uma tolerância, em que preponderava uma religião e as outras seriam apenas toleradas.

Atualmente, não há mais este caráter de preponderância ou de desigualdade entre as religiões. A liberdade religiosa tornou-se um direito individual fundamental, que

${ }^{42}$ LOPEZ CASTILLO, Antonio. Acerca del derecho de libertad religiosa. Revista Española de Derecho Constitucional, Madrid. v.19. n.56, mar./ago. 1999, p. 88-9.

${ }^{43}$ LOPEZ CASTILLO, Op. cit., p. 86-7.

${ }^{44}$ LOPEZ CASTILLO, Op. cit,, p. 87. 
independe de quaisquer fatores externos, tais como número de adeptos. Tal ocorre, pois a liberdade religiosa decorre diretamente da liberdade de pensamento. ${ }^{45}$

Ainda que a consagração da igualdade entre as religiões seja constitucionalmente aceita por grande parte dos países ocidentais, os conflitos religiosos que iremos estudar demonstram que a igualdade passa a ser mera teoria e que a preponderância de uma religião ou ideologia ainda move as decisões judiciais e legislativas.

O respeito à liberdade de opinião passaria pelo aspecto da indiferença, ou seja, de não considerar a opinião em si. Mas há um outro aspecto do respeito à liberdade de opinião que se apresenta de uma maneira inversa. Ao invés de ser indiferente às opiniões políticas ou religiosas, o Estado passa a considerá-las, com o intuito de que não venham a sofrer nenhum atentado. Neste caso, há uma discriminação, mas uma discriminação favorável.

A liberdade religiosa pode ser exercida tanto pelo direito de aderir a uma crença quanto pelo direito de se distanciar dela. No caso do ateísmo, o problema fica mais fácil, pois não há nenhum tipo de obrigação moral ou individual. Agora, havendo a predominância de uma religião, o problema surge com a necessidade de o indivíduo exercer a sua crença e ao mesmo tempo ter que respeitar outras religiões. Surge, assim, o problema da liberdade de culto.

Aparece a necessidade de haver um respeito por exigência de uma opinião religiosa. A França, pelo seu Conselho de Estado, já reconheceu que um ministro de culto pode, não obstante o caráter laico do serviço público e a regra da neutralidade, servir em um estabelecimento hospitalar de onde os internos não podem sair (decisão de 1947). ${ }^{46}$

Segundo François Bellanger, ${ }^{47}$ a liberdade religiosa é um direito imprescritível e inalienável, que protege cada cidadão contra toda ingerência do Estado de modo a minar suas convicções religiosas. Ela impõe ao Estado um dever de neutralidade confessional, proibindo as autoridades estatais de intervir na escolha das crenças de um indivíduo ou de limitar de maneira injustificada a prática ou a expressão de convicções

\footnotetext{
45 MIRANDA, Pontes. Democracia, liberdade, igualdade (os três caminhos). 2 ed. São Paulo: Saraiva, 1979 , p. 358.

${ }^{46}$ COLLIARD, Claude Albert. Libertes publiques. 7 ed. Paris: Dalloz, 1989, p. 417-8.

${ }^{47}$ BELLANGER, François. Sectes, religions et dérives sectaires in L'État face aux derives sectaires: actes du colloque du 25 novembre 1999. Bâle, Genève, Helbing \& Lechtenhann: Faculte de droit de Genève, 2000, p. 30-3.
} 
religiosas. Essa liberdade garante também o direito de não crer em Deus e de assim se proclamar.

O autor cita uma decisão do Tribunal Federal suíço que entende não ser competente para se pronunciar acerca do valor teológico de crenças religiosas, muito menos para interpretar os textos que baseiam a crença. Entendeu, porém, o Tribunal que ele poderia analisar os aspectos ou efeitos sociais da prática de uma religião.

Tal compreensão reflete aspectos essenciais da posição do Estado frente à laicidade. Não cabe ao Estado determinar ou analisar o fundamento das religiões e suas crenças, mas sim cuidar de seus reflexos sociais e com outros direitos fundamentais.

Neste sentido, a liberdade religiosa não protege as profissões de fé que servem, de fato, a argumentos de venda para uma atividade comercial. Essa atividade é protegida pela liberdade de comércio e de indústria e não tem nada de religiosa. A liberdade religiosa protege todas as crenças que tenham uma certa significação essencial e filosófica e que exprimam uma visão global do mundo.

De um ponto de vista jurídico, a liberdade religiosa visaria a todas as crenças identificáveis, de tal forma que a qualificação da crença como religião, seita, culto, doutrina ou dogma não tem nenhuma incidência sobre a eventual proteção jurídica de que elas se beneficiam em face da Constituição.

Não existiria nenhuma diferença entre as seitas, as religiões e as crenças. Importaria somente o conteúdo espiritual, o rótulo, às vezes de origem não controlada, não tem nenhuma importância.

O direito à liberdade religiosa protege o foro interno das pessoas, de modo que as questões de fé não podem sofrer qualquer tipo de pressão. Trata-se de um conceito de liberdade negativa, uma verdadeira liberdade no sentido jurídico do termo. A liberdade religiosa deve ser vista, portanto, como um conceito quadro, cujo preenchimento é prerrogativa essencial da personalidade. ${ }^{48}$

A liberdade de crença envolve, neste sentido, a possibilidade da reversibilidade das opções de fé, afinal, sendo variável a liberdade de consciência também o será a liberdade de crença. ${ }^{49}$

É importante lembrar que não é apenas o Estado o único a ter obrigações para que seja garantido um ambiente de plena liberdade religiosa. Seriam deveres do indivíduo: a) apresentar a sua fé e sua crença de maneira positiva, em vez de criticar as

\footnotetext{
${ }^{48}$ MACHADO, 1996, pp. 220-1.

${ }^{49}$ MACHADO, Op. cit., pp. 221-2.
} 
outras convicções; b) respeitar as opiniões e as ações daqueles que têm uma fé diferente; c) conferir plenamente a outro a liberdade que ele reclama a si mesmo; d) não alterar a liberdade espiritual dos outros, tentando fazer ser aceita uma convicção através da oferta de vantagens materiais ou sociais; e) cooperar com outros organismos, religiosos ou não, cada vez que um fim e alguns métodos devam ser aceitos em comum; f) respeitar as leis e se, a consciência não puder se submeter a elas e se todas as tentativas legais e a utilização de todos os meios lícitos não permitirem obter satisfação, aceitar lealmente as sanções impostas. $^{50}$

A Convenção Europeia de Direitos do Homem prevê, em seu art. $9^{\circ}$, os direitos dos indivíduos no que diz respeito à liberdade religiosa: "a liberdade de mudar de religião, assim como a liberdade de manifestar a sua religião ou sua convicção individual ou coletivamente, em público ou em particular, através do culto, do ensino e de práticas ou de acompanhamento de ritos".

Como é de se imaginar o primeiro direito relacionado com a liberdade religiosa é o direito de escolher a religião. Contudo, o texto da Convenção trata apenas do direito a mudar de religião, forçoso, portanto, indagar acerca da possibilidade de escolha originária da religião. Considerando que dificilmente uma pessoa escolherá a sua religião originária, uma vez que frequentemente ela será determinada pelos seus pais ou superiores, faz sentido que o texto da Convenção trate apenas da mudança de religião e não de sua escolha. $^{51}$

O direito à escolha de uma religião envolve também o acesso livre a informações e opiniões, tal como explicitado no art. 19 da Declaração Universal de Direitos do Homem. ${ }^{52}$

Tal direito de mudar de religião envolve, inclusive, a possibilidade de o ateu passar a adotar uma religião, o que significaria a passagem da liberdade de consciência para a liberdade religiosa. Obviamente que o caminho inverso seria igualmente permitido.

Consolida-se, assim, o direito de se converter. O Estado deve garantir o pluralismo religioso, sem impor qualquer tipo de embaraço injustificado a qualquer religião. Está vedado ao Estado, sob o pretexto de manutenção da ordem pública, perseguir e eliminar uma religião.

\footnotetext{
${ }^{50}$ LANARES, 1964, p. 27.

${ }^{51}$ GONZALEZ, Gérard. La convention européenne des droits de l'homme et la liberté des religions. Paris: Economica, 1997, p. 91-2.

${ }^{52}$ LANARES, Op. cit., p. 53.
} 
O direito de mudar de religião permanece incólume, inclusive, aos prisioneiros. Importante discutir, portanto, como se dá o exercício do direito de mudar de religião.

O primeiro ponto relevante é a liberdade de acesso a todo tipo de conhecimento. Tal não costuma ser um problema em sociedades democráticas. A Corte Europeia, neste sentido, já se pronunciou afirmando que a liberdade de manifestar a sua religião passa pelo direito de convencer o próximo, inclusive através do ensino, sem o qual o direito de mudar de religião, inscrito no art. $9^{\circ}$ da Convenção, restaria letra morta.

Seria válido assim o proselitismo não abusivo, como condição para permitir o exercício da liberdade de mudar de religião. Deveria ser proscrito apenas o proselitismo que se utiliza de métodos coativos. ${ }^{53}$

A liberdade religiosa somente será plena se houver uma plena correspondência entre crença e conduta. Afinal, se o cidadão for impedido de atuar conforme a sua crença, a liberdade não terá grande valia na vida quotidiana. Assim, um regime que permita a liberdade religiosa deve proteger ao máximo as condutas religiosas, independentemente de elas serem convencionais ou não. ${ }^{54}$

Assim, a proteção do fenômeno religioso não pode deixar de abranger os comportamentos idôneos à aquisição do consentimento e da adesão de outros à própria e à comunidade em que esta eventualmente se exprime. A liberdade religiosa compreende um direito à divulgação das convicções religiosas, sem a proteção do qual a liberdade de mudar de religião não faz muito sentido. ${ }^{55}$

O proselitismo tem sido um dos maiores motivos para a restrição da liberdade religiosa, o que normalmente demonstra uma ligação oculta entre o Estado e uma religião dominante. A proibição do proselitismo envolve frequentemente discussões acerca da proteção da dignidade humana e da personalidade. Contudo, é preciso ter cuidado para que a verdadeira proteção à dignidade da pessoa humana não se confunda com uma tentativa de enquadrar as religiões minoritárias a padrões regularmente estabelecidos pela sociedade e pela religião dominante.

Obviamente que o proselitismo somente pode ser permitido dentro do princípio da tolerância e do respeito incondicional aos direitos fundamentais de todo o

\footnotetext{
${ }^{53}$ GONZALEZ, 1997, p. 92-100.

${ }^{54}$ MACHADO, Liberdade religiosa numa comunidade...1996, p. 222-4.

${ }^{55}$ MACHADO, Op. cit., p. 225.
} 
cidadão. Não deve, contudo, o proselitismo sofrer uma proibição genérica sem análise concreta de uma eventual agressão aos direitos fundamentais. ${ }^{56}$

Raymond Goy $^{57}$, tratando da Convenção Europeia, relembra que também ela estabelece requisitos para que uma pessoa possa ter garantido os direitos decorrentes da Convenção. As pessoas garantidas são pessoas físicas, grupos de particulares e organizações não governamentais. Em primeiro lugar, a pessoa reclamante deve ser vítima efetiva e direta da violação, que pode ser cometida pelos Estados signatários, por meio seja do legislador seja do administrador seja do juiz.

Entende-se que a liberdade religiosa pode ser limitada pela Administração do Estado, pelas obrigações profissionais, legais ou contratuais. Tais limitações devem ser respeitadas por funcionários de um Estado laico ou de um ministro de culto do Estado.

Ademais, é importante lembrar que a liberdade de religião deve ser garantida pelo Estado e não por outras instituições. Contudo, deve o Estado não somente respeitar a liberdade religiosa, mas também fazê-la ser respeitada, principalmente, por outras Igrejas. Em certa medida, a liberdade religiosa deve ser garantida pelos particulares, na medida em que ela é concretizada pelo Estado. A garantia de tal liberdade deve ser imposta aos indivíduos pelo Estado pela via da regulamentação ou pela sanção às violações Mas a liberdade de religião não é garantida pelos indivíduos em suas relações privadas.

O Pacto de São José da Costa Rica, em seu art. $12,{ }^{58}$ trata da liberdade religiosa de maneira bastante ampla, inclusive, ultrapassando a proteção conferida pela Constituição Federal de 1988.

A alínea 1 afirma a liberdade de religião, enfatizando que ela envolve também a liberdade de conservar a religião ou crença e também a liberdade de mudança. Ademais, explicita estar garantido igualmente o direito de professar e divulgar uma

${ }^{56}$ MACHADO, Op. cit., p. 227-8.

${ }^{57}$ GOY, Raymond. La garantie européenne de la liberte de religion. L'article 9 de la Convention de Rome. Archives de Philosophie du Droit, Paris, n. 38, 1993, p. 169-184.

${ }^{58}$ Artigo 12 - Liberdade de consciência e de religião

1. Toda pessoa tem direito à liberdade de consciência e de religião. Esse direito implica a liberdade de conservar sua religião ou suas crenças, ou de mudar de religião ou de crenças, bem como a liberdade de professar e divulgar sua religião ou suas crenças, individual ou coletivamente, tanto em público como em privado.

2. Ninguém pode ser submetido a medidas restritivas que possam limitar sua liberdade de conservar sua religião ou suas crenças, ou de mudar de religião ou de crenças.

3. A liberdade de manifestar a própria religião e as próprias crenças está sujeita apenas às limitações previstas em lei e que se façam necessárias para proteger a segurança, a ordem, a saúde ou a moral públicas ou os direitos e as liberdades das demais pessoas.

4. Os pais e, quando for o caso, os tutores, têm direito a que seus filhos e pupilos recebam a educação religiosa e moral que esteja de acordo com suas próprias convicções. 
religião ou crença. Direito este que não está expressamente garantido em nossa Magna Carta.

Os limites à liberdade religiosa estão revelados na alínea 3, com a ressalva de que tais limites somente poderão ser impostos por lei e na medida em que sejam necessários para garantir a segurança, a ordem, a saúde, a moral públicas ou os direitos de outras pessoas. Nada de novo introduz o Pacto acerca das limitações aos direitos fundamentais, apenas explicita a necessidade de a restrição de um direito ocorrer na medida em que seja necessária para garantir outro bem igualmente protegido.

Quando se discute a liberdade religiosa muitos outros temas afiguram-se relevantes, principalmente, no cenário internacional. O primeiro deles é o das minorias religiosas, que a partir de 1992 passou a ser amplamente discutido na ONU. O Pacto Internacional de Direitos Civis e Políticos, em seu art. 27, prevê que: "nos Estados em que há minorias étnicas, religiosas ou lingüísticas, as pessoas pertencentes a essas minorias não poderão ser privadas do direito de ter, conjuntamente com outros membros de seu grupo, a própria vida cultural, de professar e praticar sua própria religião e usar sua própria língua".

Ao que parece este artigo é a única norma jurídica com poder vinculante entre os Estados signatários que protege as minorias. É de se lembrar que a Constituição Federal de 1988 não trata explicitamente das minorias religiosas. Considerando, porém, a sistemática de incorporação de tratados internacionais de direitos humanos ao ordenamento brasileiro, é possível considerar que tais regras integram em âmbito constitucional o ordenamento pátrio. ${ }^{59}$

A despeito de não haver nenhuma norma constitucional explícita acerca das minorias religiosas, do conjunto de dispositivos constitucionais pode-se facilmente extrair a garantia a eles. A Constituição, ao garantir a liberdade religiosa e ao proscrever a discriminação, protege as minorias (religiosas, étnicas), de quaisquer atos, seja do Estado seja de particulares, que impeçam ou dificultem o pleno exercício de suas liberdades fundamentais.

Ainda sob o enfoque do direito internacional, é importante citar o conceito de refugiados trazido pela Convenção de 1951:

A expressão refugiado se aplica a qualquer pessoa que, em virtude de fundado medo de sofrer perseguição por motivos de raça, religião, nacionalidade, participação em determinado grupo social ou convicção

\footnotetext{
${ }^{59}$ SORIANO, A., 2002, p. 109-112.
} 
política, se encontra fora do país do qual é nacional e está impossibilitada ou, em virtude desse fundado medo, não deseja entregar- se à proteção desse país. ${ }^{60}$

\section{I.3.1- Limites à liberdade de consciência}

Após analisados os aspectos mais relevantes atinentes à liberdade de consciência, é interessante trazer à tona o tema já iniciado acerca dos seus limites. Como todo direito fundamental, a liberdade de crença também tem como uma de suas características a sua relatividade, cujo principal objetivo é permitir a convivência harmônica entre os demais direitos fundamentais inscritos no texto constitucional.

Não se tratará aqui do tema da restrição dos direitos fundamentais em geral, mas tão somente das especificidades atinentes à liberdade de crença religiosa.

Para Rámon Soriano ${ }^{61}$, este princípio de liberdade religiosa não é um princípio absoluto; os princípios, como os direitos e as liberdades, são relativos e estão submetidos ao jogo de recíprocas limitações com o fim de dosar seu exercício e fazer frente a um hipotético abuso cometido por algum deles. Também são relativos porque seu conteúdo e alcance admitem internamente diversas configurações em função das opções ideológicas e das políticas.

A título de exemplo, a Constituição espanhola coloca explicitamente três princípios aptos a restringir a liberdade religiosa, quais sejam: a igualdade religiosa, a cooperação e a ordem pública. Na verdade, o autor entende que a liberdade é mais um limite à igualdade religiosa do que o contrário, já que é forte o risco de a liberdade tornarse um privilégio e nesta medida ameaçar a igualdade. Do mesmo modo, o princípio da cooperação seria mais um limite à igualdade do que à liberdade. O único limite verdadeiramente imposto à liberdade religiosa seria a ordem pública.

Como integrantes da ordem pública poderiam ser incluídos os direitos alheios, a segurança, a saúde e a moralidade públicas. Contudo, todos os altos valores constitucionais podem ser opostos ao exercício da liberdade religiosa. Remonta-se à ideia de que todas as normas constitucionais tanto as que preveem a liberdade quanto as que impõem as restrições vivem num regime de concorrência normativa e não de exclusão. ${ }^{62}$ Assim, restou decidido pelo Tribunal Constitucional Espanhol:

\footnotetext{
${ }^{60}$ SORIANO, A., Op. cit., p. 112

${ }^{61}$ SORIANO, R., 1990, p. 85

${ }^{62}$ LOPEZ CASTILLO, 1999, pp. 93-103.
} 
[...] tanto as normas que regulam a liberdade como as que estabelecem limites a seu exercício vem a ser igualmente vinculantes e atuam reciprocamente. Como resultado desta interação, a força expansiva de todo direito fundamental restringe, por sua parte, o alcance das normas limitadoras que atuam sobre o mesmo; daí a exigência de que os limites dos direitos fundamentais tenham de ser interpretados com critérios restritivos e no sentido mais favorável à eficácia e à essência de tais direitos. (STC 20/1990) [tradução nossa]

É interessante notar que tradicionalmente apontava-se a ordem pública como o grande limite aos direitos fundamentais. Analisando-se o conceito de ordem pública, pode-se perceber que ele envolve os mais célebres valores constitucionais. Atualmente, não se costuma mais falar em ordem pública como limite, mas sim nos demais princípios e dispositivos constitucionais.

A mudança não está na essência, mas sim na conotação mais democrática que hoje se confere à restrição de direitos fundamentais. Invocar a ordem pública para impor limites a um direito fundamental remete a uma ideia de autoritarismo, em que os direitos seriam tolhidos sem nenhum pretexto.

Hoje, contudo, a restrição de um direito fundamental passa por uma cautelosa análise da situação que o envolve, bem como de uma ponderação jurídica acerca dos princípios colidentes.

Tratando-se de limites concretos à liberdade religiosa, bastante esclarecedora é a decisão no Caso Arrowsmith (1977), acerca do texto do artigo 9 da Convenção de Roma. Segundo a Corte, o termo "prática" empregado pelo texto não é apto a proteger todos os atos motivados ou influenciados pela religião. Assim, os atos que de fato não exprimem uma crença, apesar de terem um mote religioso, não são alvo de proteção.

Apontam-se, assim, alguns casos em que a liberdade religiosa a priori poderia ser restringida: a) prerrogativas do Estado, tais como, o serviço militar e a obrigação de pagar imposto; b) regulamentações emanadas do Estado e que enfrentam problemas da sociedade e.g., regras protetivas dos direitos de menores, sepulturas dos mortos, obrigações contratuais.

Voltando ao texto da Convenção, a primeira parte do artigo 9 está destinada a garantir a liberdade religiosa, enquanto que a segunda a estabelecer os casos em que ela pode sofrer restrição. A Comissão Europeia passa a entender que a despeito de a liberdade religiosa ser relativa, somente serão autorizadas as restrições expressamente previstas pelo texto da Convenção. 
A restrição válida está submetida a condições gerais: a) deve-se aplicar somente à liberdade de manifestar a religião; b) deve estar prevista em lei; c) deve ser medida necessária à sobrevivência de uma sociedade democrática. Ademais, a restrição deve ser fundada em alguns motivos, como a garantia da segurança, da ordem, da saúde, da moralidade pública ou a proteção a direitos e liberdades alheios.

Para dar um exemplo prático de restrição considerada válida pela Corte Europeia, pode ser citado o caso de um ciclista sikh que reivindicava o direito ao porte do turbante, recusando-se a usar o capacete obrigatório. A Corte, sem discutir o significado religioso do porte do turbante, responde que o porte obrigatório do capacete é uma medida de segurança necessária aos ciclistas, decidindo, portanto, pela restrição da liberdade religiosa. ${ }^{63}$

Interessante, ainda, é a posição de alguns autores de que uma das diferenças existentes entre a liberdade de manter e de mudar de religião é que a primeira não pode ser objeto de limitação enquanto que a segunda pode sofrer intervenções estatais. ${ }^{64}$

A restrição da liberdade religiosa é facilmente admitida pela doutrina de maneira teórica, o problema surge em como compatibilizar a garantia da liberdade religiosa como a imensa gama de direitos que com ela se confronta na prática. Mais adiante serão analisados diversos casos que envolvem a liberdade religiosa, com o intuito de tentar delinear alguns parâmetros para a solução do conflito.

\section{I.4- Liberdade de culto}

A liberdade de culto foi expressamente consagrada pela Constituição de 1988 na segunda parte do inciso VI do art. $5^{\circ}$. A religião caracteriza-se não apenas pela existência de uma doutrina, mas também pela prática de ritos, cultos, cerimônias. A proteção ao culto é, portanto, uma garantia imprescindível para o pleno reconhecimento da liberdade religiosa. ${ }^{65}$

"Na verdade, não existe religião sem culto, porque as crenças não constituem por si mesmas uma religião. Se não existe culto ou ritual, correspondente à crença, pode haver posição contemplativa filosófica, jamais uma religião." ${ }^{66}$

\footnotetext{
${ }^{63}$ GOY, 1993, p. 195-206.

${ }^{64}$ LANARES, 1964 p. 55.

${ }^{65}$ SILVA, 2010, p. 249.

${ }^{66}$ CRETELLA JR, José. Liberdades Públicas. 4 ed. São Paulo: José Bushatsky, 1974, p. 103.
} 
Cumpre, então, fazer uma diferença entre a liberdade de consciência e a liberdade de culto. Cretella $\mathrm{Jr}^{67}$ entende que a consciência diria respeito a uma questão interior do indivíduo, enquanto que o culto teria relação com as cerimônias praticadas externamente. Da mesma forma em que existe uma diferença entre o pensamento e a sua manifestação, existiria a mesma diferença entre a fé interior e aquela que é exteriorizada. Seria, assim, o culto a "manifestação das próprias crenças religiosas do mundo externo, o conjunto de todos os atos externos, práticas e omissões, com os quais se exterioriza a fé religiosa."

A consagração da liberdade de consciência não acarreta necessariamente a liberdade de culto, no entanto, esta pressupõe a liberdade de consciência (que, conforme já dissemos, depende da liberdade de opinião). Nesse sentido, costuma-se dizer que a liberdade de consciência seria absoluta, pois se desenvolveria no aspecto íntimo do indivíduo, enquanto que a liberdade de culto poderia ser limitada pelo ordenamento.

A garantia à liberdade de crença acabou resultando na proteção à liberdade de culto. Apesar de crença e culto poderem ser racionalmente separados, a religião perde sentido sem o culto. ${ }^{68}$ Dentro da liberdade de culto, é possível inserir todas as condutas que envolvam a opção religiosa do indivíduo, já que não há liberdade de religião sem a garantia de livre estabelecimento de cultos. ${ }^{69}$

Através do culto, os crentes estão autorizados a praticar atos que para eles tenham como intuito a comunicação com Deus. O culto envolve, assim, a construção de templos, a celebração de cerimônias. O culto não significa apenas a realização pública de atos, mas sim a necessidade de prestar homenagem coletivamente ao Deus de sua crença. Pode, dessa maneira, haver liberdade religiosa sem liberdade de culto, mas não liberdade de culto sem a religiosa. ${ }^{70}$

É preciso fazer referência, ainda, à expressão liturgia que "significa o culto público e oficial instituído por uma igreja. É o ritual. É a manifestação externa que dita as normas do próprio culto. São as cerimônias que cercam o culto." ${ }^{71}$

O culto é, assim, a forma exterior da religião. Há quem entenda que culto e religião são sinônimos, de modo que um não poderia existir sem o outro. Tal afirmação é

${ }^{67}$ CRETELLA JR., Op. cit., p. 102-4.

${ }^{68}$ FERREIRA FILHO, Manoel Gonçalves. Religião, Estado e Direito. Revista Direito Mackenzie, São Paulo. v.3. n.2. 2002, p. 81-89.

69 BASTOS, 2001.

${ }^{70}$ DÓRIA, 1942, p. 599.

${ }^{71}$ FERREIRA, Wolgran Junqueira. Direitos e garantias individuais - comentários ao artigo $5^{\circ}$ da CF/88. São Paulo: Edipro, 1997, p. 157. 
equivocada. A parte mais visível do culto é a cerimônia que pode perfeitamente existir sem religião. $^{72}$

Também a Declaração de Direitos Humanos da ONU, em seu artigo 6, garante a manifestação exterior da religião. A liberdade religiosa envolve assim diversos aspectos. $\mathrm{O}$ formalismo de uma religião, o aparato que acompanha certos atos de adoração, as solenidades dos lugares que lhes servem de palco, o número e o papel dos ministros de culto, a manutenção de ritos complexos em torno do exercício da função cerimonial têm por finalidade, em toda a fé, de magnificar o deus ao qual se presta homenagem, de acompanhar a doutrina de uma religião a fim de reforçar a autoridade e de testemunhar a unidade de todos aqueles que acompanham escrupulosamente os mesmos gestos, têm posturas idênticas, pronunciam palavras semelhantes para além das fronteiras.

A liberdade de manifestar a religião pode ser exercida de maneira individual ou coletiva, em público ou em particular (nos moldes do que dispõe o artigo 9-1 da Convenção Europeia de Direitos Humanos). Tem o Estado a obrigação de garantir que a liberdade religiosa seja exercida em todas estas facetas. ${ }^{73}$

Atualmente, ganham relevância os novos movimentos religiosos, que podem basicamente ser de duas espécies: a) grupos constituídos por uma Igreja para sustentar opiniões teológicas particulares (seitas); b) organizações fechadas que exercem forte influência sobre seus adeptos, através de um pensamento religioso ou místico, sem guardar relação com nenhuma religião constituída. Da mesma forma que as religiões tradicionais, tais movimentos novos merecem as mesmas garantias e liberdades às primeiras conferidas. $^{74}$

A liberdade de culto nem sempre foi amplamente conferida a todas as religiões no Brasil. A Constituição do Império garantia a liberdade de culto somente para a religião católica, que era a religião oficial do Império. Às outras religiões, era apenas garantido o culto doméstico. ${ }^{75} \mathrm{O}$ Estado claramente garantia uma proteção especial à Igreja Católica Apostólica Romana, restringindo o culto público das demais religiões. ${ }^{76}$

\footnotetext{
72 MIRANDA, 1979, p. 365.

${ }^{73}$ GONZALEZ, 1997, p. 104-9.

${ }^{74}$ DUFFAR, Jean. Les nouveaux mouvements religieux et le droit international. Revue du Droit Public et Science Politique en France et à l'Etranger, Paris. n.4. p.1037-56. 1998, p. 1044.

${ }^{75}$ SILVA, 2010, p. 249.

${ }^{76}$ BUENO, 1857, p. 398.
} 
Para que seja conferida a garantia da liberdade de religião a um movimento é imprescindível definir se a organização em questão é dotada de caráter religioso. A Corte Europeia de Direitos Humanos em julgado de 1976 entendeu que:

[...] somente existe o caráter religioso se é percebida a existência de religiões que formam um conjunto dogmático e moral bastante amplo, que pode fornecer resposta a toda questão de ordem filosófica, cosmológica ou ética. Por essa descrição, percebe-se a distância que separa alguns novos movimentos religiosos das religiões [tradução nossa]. ${ }^{77}$

Neste sentido, uma convicção religiosa não teria o mesmo significado de religião e nem todos os atos ligados a uma religião mereceriam a proteção da liberdade religiosa. Assim, uma sociedade comercial ligada a uma Igreja não deve ter seus atos considerados como integrantes do culto religioso, passível de proteção. ${ }^{78}$

Retorna-se aqui a um problema constante relacionado à liberdade religiosa. Não é pelo fato de determinada atividade estar ligada a uma religião que ela deva automaticamente merecer ampla proteção constitucional se ela não estiver representando uma verdadeira crença religiosa. Caberia, assim, ao Judiciário tentar separar atividades praticadas por religiosos de atividades praticadas em razão de verdadeiro culto religioso. Com o cuidado de não realizar julgamento sobre o mérito das crenças religiosas, o que escaparia ao escopo da laicidade estatal.

A Constituição de 1988 consagrou amplamente a liberdade de culto, retirando, inclusive, o condicionamento à observância da ordem pública e dos bons costumes, como o faziam as Constituições precedentes. ${ }^{79}$

A Convenção Europeia de Direitos do Homem, em seu art. 9, trata da liberdade de manifestar a religião. Tal liberdade não se confunde meramente com a liberdade de expressão que é garantida pelo art. 10. O art. 9 protege especificamente a manifestação de atos significativos para a religião, tendo como objeto de proteção tanto o foro interno do indivíduo quanto atos exteriores de devoção.

A Comissão Europeia entende, contudo, que para receber a proteção da Convenção deve o indivíduo invocar uma religião existente, em que ele de fato acredite. Uma religião hipotética não serve para embasar um pedido de garantia. Ademais, um ato

\footnotetext{
${ }^{77}$ DUFFAR, Op. cit., 1998.

${ }^{78}$ DUFFAR, 1998, pp.1037-56.

${ }^{79}$ SILVA, 2010, p. 249.
} 
somente merece proteção da Convenção, caso ele constitua elemento necessário à prática da religião. ${ }^{80}$

A despeito de a Constituição de 1988 não ter feito expressa referência à necessidade de os cultos respeitarem os bons costumes e a ordem pública, tal omissão não deve levar à conclusão de que os cultos estão autorizados a desenvolverem-se sem quaisquer limites. A observância da ordem pública é aspecto inerente à manutenção de um ordenamento jurídico, parecendo, portanto, bastante razoável que devam os cultos respeitála. ${ }^{81}$

Há quem entenda, ${ }^{82}$ neste sentido, que os cultos e os ritos religiosos não deveriam ser deixados ao arbítrio pessoal, pois fazem parte da organização da própria religião e são responsáveis pela união de seus membros. Somente as formulações pessoais, tais como, a prece, devem ser relegadas ao âmbito individual, já que integram o foro interno da crença. No que diz respeito aos cultos, exatamente pelo fato de eles fazerem parte da congregação dos membros de uma Igreja, a liberdade religiosa deixa de ser da Igreja e passa a ser de seus membros.

O papel de um ministro de culto não pode ser o de decidir e organizar o culto, mas somente de celebrá-lo de acordo com as regras impostas.

Exatamente pelo fato de os cultos terem lugar, normalmente, em público ou coletivamente, pode haver restrições e limitações caso venham a confrontar-se com outras religiões. Em tal ocorrendo, caso o culto tenha que ser restringido, ela ainda poderá desenvolver-se de maneira particular e mesmo assim coletivamente. Sendo o culto particular, não há que se pensar na sua limitação, pois dificilmente um culto particular irá causar transtornos públicos.

Assim como qualquer direito fundamental, também a liberdade religiosa deve ser considerada relativa. Não podem os cultos praticar atos contrários à lei, sob pena de serem responsabilizados civil e criminalmente. Devem os cultos religiosos, por exemplo, respeitar a ordem, a tranquilidade, o sossego públicos e os bons costumes. Além do que, não podem os cultos ser praticados de modo a obstar a liberdade religiosa dos outros indivíduos. $^{83}$

\footnotetext{
80 GOY, 1993, p. 188-190.

${ }^{81}$ FERREIRA FILHO, Curso de direito..., 2002, p. 290.

${ }^{82}$ GONZALEZ, 1997, p. 107-112.

${ }^{83}$ MORAES, 2011, p. 132.
} 
Pelo contrário, sempre que os cultos desenvolverem-se de maneira pacífica sem contrariar a ordem pública, será vedada qualquer tipo de intervenção estatal. Para fins de possibilidade de intervenção, é interessante distinguir entre as manifestações religiosas que ocorrem nos templos, tais como, missas, serviços religiosos, confissões, comunhões, cantos, batizados, casamentos, e aquelas que se desenvolvem no exterior, como procissões, romarias. ${ }^{84}$

"É inegável que o Estado tem o direito-dever de exercer o poder de polícia sobre os cultos religiosos. Estes não são direitos absolutos; ao contrário, são direitos relativos." ${ }^{85}$ Tradicionalmente, colocam-se como limites a ordem pública e os bons costumes.

A liberdade de culto pode colidir com outros direitos fundamentais, o que pode implicar a sua restrição. Eis o caso de uma procissão que gere conflitos ou que simplesmente afete a circulação de pessoas e veículos. ${ }^{86}$

Para ilustrar o cenário apresentado, Maria Luiza Whately Barreto cita acórdão do Tribunal de Justiça de São Paulo em que foi negado seguimento à apelação contra decisão que julgou improcedente mandado de segurança contra fechamento de um templo. In verbis:

\begin{abstract}
A nosso ver, a referida decisão encontra-se embasada de fundamentos, pois a apelante várias vezes foi notificada para regularizar sua situação; não tomando conhecimento de tais notificações, preferiu desrespeitar normas municipais e direitos alheios (direito de seus vizinhos).

Todavia, referida garantia [liberdade religiosa] não inibe o exercício da autoridade de polícia administrativa, posto que a apelante estava prejudicando o sossego alheio, isto é, dos moradores vizinhos que se viam obrigados a ouvir o que lhes transmitia a sua aparelhagem de som em proporções desmedidas. Desta forma, a apelante desrespeitou os direitos fundamentais de seus vizinhos, sendo eles: o direito à intimidade (art. 5o, X, da Constituição Federal) e a própria liberdade de consciência e de crença (art. 5o, VI, da Constituição Federal), da qual reclamava a apelante estar sendo privada. ${ }^{87}$
\end{abstract}

Há quem admita ${ }^{88}$, inclusive, a atuação do Estado para impedir as falsas manifestações religiosas. Caberia ao Estado, portanto, verificar a existência de dois

\footnotetext{
${ }^{84}$ BARRETO, Maria Luiza Whately. Exercício da liberdade religiosa. Cadernos de Direito Constitucional e Ciência Política, n. 14, 1996, p. 250.

${ }^{85}$ FERREIRA, W., 1997, p. 155.

${ }^{86}$ FERREIRA FILHO, Curso de direito...2002, p. 89.

${ }^{87}$ BARRETO, 1996, p. 251.

${ }^{88}$ BASTOS, 2001, p. 493-507.
} 
requisitos: boa-fé dos promotores do culto e da seita e a ausência de práticas que firam os princípios consagrados na ordem jurídica.

Cretella Jr. ${ }^{89}$ cita como leading case da possibilidade de restrição da liberdade de culto no Brasil um mandado de segurança julgado pelo STF em 1949. A Igreja Católica Apostólica Brasileira foi impedida de realizar um culto externo, o que a levou a impetrar mandado de segurança, pleiteando a permissão para a realização do pretendido culto. O STF acabou denegando a segurança, sob o fundamento de que a Igreja Católica Apostólica Brasileira se utiliza dos mesmos ritos e indumentárias da Igreja Católica Apostólica Romana, o que poderia gerar um conflito entre as duas igrejas durante um culto externo, ferindo assim a ordem pública. $\mathrm{O}$ ato da autoridade coatora, apesar de limitativo, foi considerado legítimo, pois representou o uso moderado do poder de polícia.

Nesse sentido, parece ser unânime a doutrina em entender que a liberdade de culto, para ser exercida, deve combinar-se com a ordem pública. Cabe ao Estado intervir na prática religiosa quando estiverem sendo desrespeitados preceitos garantidores da ordem pública. Pode-se admitir inclusive que a autoridade pública pró́ba o funcionamento de uma Igreja que represente perigo para a sociedade..$^{90}$

O inciso VI do art. $5^{\circ}$ da $\mathrm{CF} / 88$ estabelece que a proteção aos locais de culto e a suas liturgias será feita na forma da lei. Os cultos podem tanto ocorrer internamente, i.e., dentro de templos, quanto externamente, nas vias públicas. ${ }^{91}$ Podendo os cultos ocorrer em quaisquer lugares e não necessariamente dentro de templos, é imperiosa a submissão de tais práticas a outros princípios da ordem jurídica, mesmo não tendo a Constituição feito expressa referência a tais limites. ${ }^{92}$

Assim, mesmo que um culto se revele exteriormente, se for realizado de maneira particular, não há que se falar em restrição, a não ser que ofenda a moralidade e a ordem públicas ou os direitos alheios. Havendo ofensa a direitos estabelecidos, deixa-se de se entender a manifestação como parte da liberdade de culto, podendo assim sofrer restrições.

A partir do momento em que o culto se torna público, entende-se que o Estado tem direito de restringi-lo se assim se tornar necessário. ${ }^{93}$

\footnotetext{
${ }^{89}$ CRETELLA JR., 1974, p. 108-9.

${ }^{90}$ COLLIARD, 1979 , p. 348-9.

${ }^{91}$ CRETELLA JR, 1974 p. 107.

92 BASTOS, 2001, p. 493-507.

${ }^{93}$ BUENO, 1857, p. 397
} 
Quanto à remessa da Constituição à lei no que diz respeito à proteção dos locais de culto e de suas liturgias, entende José Afonso da Silva ${ }^{94}$ que não caberá à lei definir quais serão os locais de culto e suas liturgias. Afinal, tal definição estaria incluída na liberdade de culto e, portanto, não poderia sofrer condicionamentos. A lei deveria dispor sobre aqueles lugares que não são destinados à prática do culto, mas necessários ao exercício da liberdade religiosa.

A lei deveria estabelecer formas de proteção a tais lugares e, principalmente, aos templos, onde normalmente ocorrem os cultos. Como, contudo, os cultos podem se desenvolver em locais públicos, também deverá a lei conceder proteção a tais manifestações. $^{95}$

Bastante intrigante é a posição de Cretella $\mathrm{Jr}^{96}$ ao entender que as manifestações religiosas tradicionais não poderiam ser proibidas, a não ser que trouxessem ameaça à ordem pública. Já as manifestações não tradicionais poderiam ser limitadas de maneira mais ampla, pois não são inerentes à liberdade de culto.

Tal posicionamento não parece ser muito consentâneo com a garantia prevista pela Constituição de 1988. Conforme o disposto no art. $5^{\circ}$, VI é garantida a ampla liberdade de culto, não havendo qualquer privilégio às religiões ditas tradicionais. Não fez a Constituição qualquer restrição às religiões, pois consagrou a todas a liberdade de culto nos mesmos termos.

Entender que as manifestações de religiões não tradicionais poderiam ser mais amplamente restringidas feriria inclusive a laicidade do Estado, afinal estar-se-ia

\footnotetext{
${ }^{94}$ SILVA, 2010, p. 250.

${ }^{95}$ Não é pelo fato de a proteção aos locais de culto estar inseridos na liberdade de culto, que não poderia haver restrição por meio de lei infraconstitucional. Se tal ocorresse, estaríamos diante de uma lei restritiva de direitos fundamentais, que dependendo de como vier a ser elaborada poderá ser considerada constitucional. De acordo com Robert Alexy (Teoría de los derechos fundamentales, Madrid: Centro de Estudios Constitucionales, 2001, p. 275), para que seja possível a existência de uma verdadeira lei restritiva de direitos fundamentais, é preciso haver uma ponderação entre o direito fundamental que é restringido e os princípios que autorizam a restrição. Canotilho (Direito constitucional e teoria da constituição. 7. ed, Coimbra: Almedina, 2003, p. 452-458) entende que uma lei restritiva para ser constitucional precisa atender aos seguintes requisitos: caráter geral e abstrato, não retroatividade e princípio da proibição do excesso. No entanto, salienta o autor que o legislador infraconstitucional português não tem uma autorização geral para editar leis restritivas de direitos fundamentais. Notemos que há uma divergência doutrinária acerca dos casos em que podem ser editadas leis restritivas, se apenas quando expressamente autorizadas pela Constituição ou em quaisquer casos desde que passe a lei restritiva por um teste de proporcionalidade (Cf. ANDRADE, José Carlos de. Os direitos fundamentais na Constituição Portuguesa de 1976. Coimbra: Almedina, 1998). No caso em tela, não parece fazer muito sentido que a lei possa definir quais lugares são destinados ao culto, mas não possa disciplinar aqueles que o são. Até porque, ao delimitar os lugares que não podem servir ao culto, estabelece-se, por exclusão, aqueles que são a ele destinados.

${ }^{96}$ CRETELLA JR., 1974, p. 219
} 
criando embaraços ao exercício de algumas religiões específicas, o que é expressamente vedado pelo art. 19, I da CF.

A liberdade de culto para ser exercida plenamente necessita de um local para acolher os participantes do culto. Nada impede, contudo, que seja necessária uma autorização administrativa para abrir e fazer funcionar uma casa de prece. Segundo Jean Duffar, ${ }^{97}$ a Corte Europeia entende que um regime de autorização para os cultos somente será aceitável se o regime impuser apenas condições formais, sem restrição à atividade religiosa em si.

Importante discussão envolvendo o poder de polícia do Estado e a liberdade religiosa é a de quando uma manifestação faz parte de um pensamento verdadeiramente religioso ou quando é utilizada apenas como uma fachada para encobrir atividades delituosas.

Parece bastante complicado, a princípio, diferenciar as seitas das Igrejas tradicionais. Ademais, tal distinção não pode ser empregada com o fito de prejudicar a realização de cerimônias e cultos, sob pena de ferir a liberdade de religião e de culto.

Não é rara a ideia de que o poder de polícia relacionado ao procedimento de eventual autorização ou controle de manifestações religiosas deve analisar a verdadeira intenção do movimento, a fim de identificar eventual potencialidade de ameaça ao interesse nacional, à segurança das pessoas, aos bons costumes, à tranquilidade pública, enfim, ao interesse público. ${ }^{98}$

A despeito de ser inegável que a liberdade de culto e de religião deve ser submetida a restrições quando seu exercício confrontar-se com direitos fundamentais ou princípios constitucionais, é preciso ter bastante cautela para que seja aplicada a afirmação acima referida. Admitir a relatividade da liberdade religiosa é bastante diferente de conferir plenos poderes ao Estado para analisar o conteúdo de um movimento religioso e dar a palavra final acerca de sua regularidade. O Estado, ao realizar um juízo de mérito sobre os movimentos religiosos, para definir quais serão ou não permitidos, corre o risco de atentar frontalmente contra a liberdade de religião.

Destarte, o Estado não pode embaraçar as manifestações religiosas, desde que, organizadas na forma da lei. Além do mais, cabe ao próprio Estado garantir a proteção aos locais de culto, mediante o exercício do poder de

\footnotetext{
${ }^{97}$ DUFFAR, 1998, p. 1039-1051.

${ }^{98}$ PIERRE CAPS, Stephane. Les nouveaux cultes et le droit public. Revue du Droit Public et de la Science Politique en France et à l'Etranger, Paris, n. 4, jul./ago. 1990, p. 1084-7.
} 
polícia. Por outro lado, o Estado não pode subsidiar a religião, tampouco pode estabelecer cultos. ${ }^{99}$

As organizações religiosas por serem um tipo específico de associação submetem-se à legislação civil, mais precisamente ao Código Civil. As Igrejas são, assim, pessoas jurídicas que devem seguir as mesmas regras de constituição e funcionamento das demais pessoas jurídicas. Devem, portanto, ter o registro civil para que tenham personalidade jurídica, mediante o cumprimento de todos os requisitos legais.

A organização religiosa é, portanto, livre na forma da lei. Tal liberdade não deve ser suprimida em razão do freqüente abuso existente no exercício da liberdade religiosa. É importante lembrar que a liberdade de organização religiosa também está sob a égide da legislação penal, de modo que atividades ilícitas ainda que exercidas sob o manto da religião não serão permitidas pelo ordenamento jurídico. ${ }^{100}$

Ainda tratando da liberdade de manifestação religiosa, é interessante citar a comparação feita por Célio Borja ${ }^{101}$ entre a liberdade civil de associação (art. $5^{\circ}$, VI da $\mathrm{CF} / 88$ ) e a liberdade de agremiação religiosa (art. 50, XVII). Ressalta o autor que a primeira é definida pela Constituição como plena e a segunda como inviolável.

A plenitude, assim, permitiria regulamentação estatal inclusive naquilo que diz respeito à ilicitude de certos fins que não poderiam ser eleitos como fins formais da associação. Já a liberdade religiosa é mais do que plena, é inviolável, o que significaria sua insuscetibilidade de regulação externa.

Dessa maneira, os atos religiosos, ressalvados os atos que causem lesão a direitos e os atos não religiosos penalmente puníveis praticados pela instituição religiosa ou por seus membros, não poderiam ser regulados pelo Estado em virtude da inviolabilidade que lhes foi conferida pela Constituição.

Tal afirmação apesar de aparentemente contradizer frontalmente a idéia de relatividade de todos os direitos fundamentais, inclusive, da liberdade religiosa, guarda certa relação com esta teoria. O autor entende apenas que os atos ilícitos ou que causem lesão a direito não estariam incluídos na liberdade religiosa e, portanto, a repressão a tais condutas não significaria uma afronta à inviolabilidade da liberdade religiosa.

\footnotetext{
${ }^{99}$ SORIANO, A., 2002, p. 13.

${ }^{100}$ SORIANO, A., Op. cit., p. 14-5.

101 BORJA, Célio, O Estatuto constitucional da religião e da beneficência . Revista da EMERJ. Rio de Janeiro, v. 6, n.23, 2003, p. 102-3.
} 
Parece um pouco equivocado, contudo, o pensamento de que a inviolabilidade da liberdade religiosa não permitiria qualquer restrição ao seu exercício, o que é incompatível com um Estado Democrático de Direito, onde deve ser garantida a convivência harmônica de todos os direitos fundamentais.

Ressalte-se $^{102}$ assim que o Estado, ao tratar a liberdade de culto, deve considerar o princípio da proporcionalidade, que permite um controle das autoridades administrativas, de modo a evitar medidas drásticas, tais como um eventual fechamento do templo. Através do princípio da proporcionalidade deve o Estado lançar mão de medidas que possam permitir uma convivência harmônica entre a liberdade de culto e qualquer outro direito que venha a confrontá-la.

Alguns temas são bastante controversos no que tange à liberdade religiosa e a manifestação da sua crença. Uma das questões a ser abordada é a possibilidade de oração escolar. Há quem entenda pela sua possibilidade desde que ela ocorra nos horários correspondentes à matéria de religião oferecida na maneira voluntária. Seria uma prática abusiva caso a oração se tornasse numa prática indiscriminada.

Também ganha relevância a questão do respeito a festividades religiosas, principalmente na relação entre empregado e empregador. Em sentença do TSJ de Madrid, de 27 de outubro de 1997 (AS 1997-3751), restou decidido que deve prevalecer o princípio da boa-fé. Assim, se no momento da contratação houver um acordo acerca do descanso em razão de datas religiosas, tal acordo deverá ser respeitado. Contudo, se o contratado silenciar sobre questões religiosas no momento da contratação não poderá fazê-lo posteriormente.

${ }^{102}$ LÓPEZ CASTILlO, Antonio. Revista Española de Derecho Constitucional, Madrid. v.21. n.63. p.1142. sept./dic. 2001, p. 26-30. 


\section{II - RELAÇÕES ESTADO E IGREJA}

\section{II.1- Modelos de Relações Estado-Igreja}

A terceira vertente da liberdade religiosa diz respeito à possibilidade de organização religiosa. Tal liberdade está diretamente relacionada com a possibilidade de estabelecimento e organização das igrejas e suas relações com o Estado.

Diversos são os modelos apresentados pela doutrina e que puderam ser verificados na História de relações entre a Igreja e os Estados.

De acordo com o modelo da confusão, o Estado é considerado teocrático, pois ele se confunde com determinada religião. É o que ocorre com o Estado do Vaticano e com os Estados Islâmicos. ${ }^{103}$ Dessa maneira, a autoridade política identifica-se com a autoridade religiosa. ${ }^{104} \mathrm{O}$ Estado transforma-se, assim, num fenômeno religioso. ${ }^{105}$ Manoel Gonçalves Ferreira Filho chama esse modelo de identificação, pois o Estado resume-se a uma religião, com seus cultos e seus sacerdotes. ${ }^{106}$

Neste modelo, pode-se dizer que inexiste qualquer dualidade envolvendo a Igreja e o Estado, a vida da cidade é uma vida religiosa. ${ }^{107}$

Havendo confusão entre Estado e Igreja, fala-se de um Estado Confessional em que inclusive os bens do Estado e da Igreja se confundem. A soberania política do Estado seria tão vasta que não poderia encontrar limites no poder religioso, que passa a ser entendido como parte integrante da soberania territorial.

Esta concepção vista sob a perspectiva católica enquadra-se como parte de uma doutrina episcopalista em que as autoridades públicas, cristãs, seriam legitimadas a pregar a verdadeira fé. Assim, os poderes políticos detinham funções de defesa, reforma, direção e fiscalização da Igreja. A confusão entre poderes políticos e religiosos era tão grande que chegou-se a denominar tal doutrina como de absolutismo confessional. ${ }^{108}$

De acordo com Jean Rivero, o cristianismo com o passar do tempo foi responsável por perpetrar uma mudança no regime anterior, passando a admitir a distinção de domínios entre religião e poder estatal. ${ }^{109}$

Na confusão entre Estado e Igreja não se pode separar um do outro, não

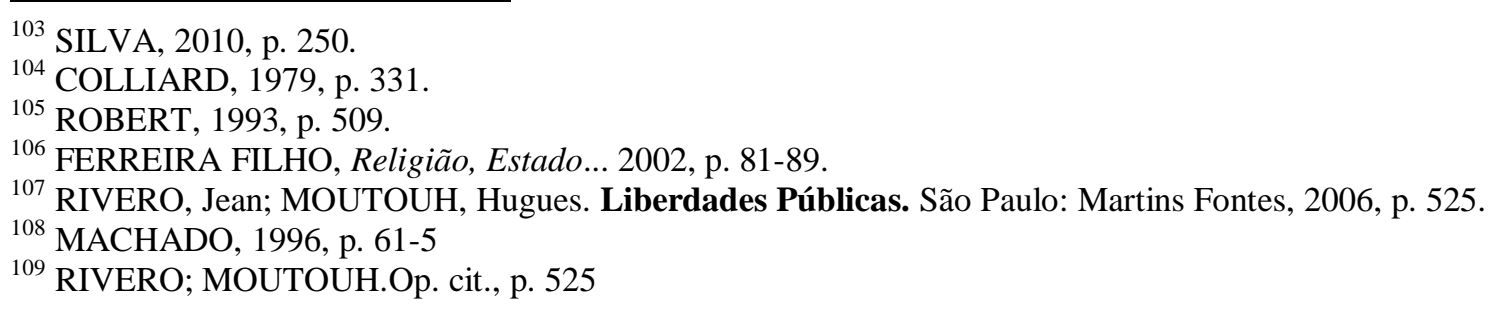


sendo possível vislumbrar qualquer diferença entre eles. Diferente desta unidade é a possibilidade de subordinação do Estado à Igreja ou pelo contrário da Igreja ao Estado. ${ }^{110}$

Esta subordinação entre Estado e Igreja por vezes gera conflitos, já que naturalmente haverá tentativa de a Igreja sobrepor-se ao Estado ou de o Estado sobrepor-se sobre a Igreja.

Havendo predominância do Estado sobre a Igreja, o regime é chamado de cesaro-papismo. Pelo contrário, havendo predominância da Igreja, trata-se de um regime teocrático. ${ }^{111}$ Tais modelos, teocráticos ou cesaropapistas:

[...] assentavam na idéia de sociedade hierarquizada em que as questões de consciência e de fé eram resolvidas por manifestações de poder político-religioso centralizadas e unilaterais. [...] Por um lado, a Igreja enfatiza os direitos da verdade tal como ela própria a compreende, juntamente com o dever estadual da sua proteção e promoção. Por outro lado, o príncipe estendia à Igreja os princípios teorético-políticos da soberania e da territorialidade, alargando automaticamente aos seus súditos a sua própria religião. Em qualquer dos casos, verificava-se uma total obliteração das prerrogativas mais elementares da personalidade. ${ }^{112}$

Pelo sistema da união, existem relações jurídicas entre o Estado e certa Igreja, principalmente no que diz respeito à sua organização e a seu funcionamento. Foi esse o sistema estabelecido pela Constituição de 1824 , durante o Império. ${ }^{113}$ Por esse modelo, há apenas uma união entre o Estado e a autoridade religiosa. ${ }^{114}$

O sistema da união é, portanto, menos radical que o sistema da confusão. Dentro desse modelo, há o chamado sistema das Igrejas reconhecidas, pelo qual o Estado reconhece a existência de algumas Igrejas. Pode ocorrer, contudo, que dentre tais igrejas reconhecidas, exista uma a que o Estado confira maior proeminência, sendo assim compreendida como a religião oficial do Estado. ${ }^{115}$ Existe, na verdade, uma aliança entre o Estado e uma Igreja, mas há uma diferença entre o fenômeno político e o religioso, que apesar de ligados não se confundem. A Igreja abençoa o Estado e este a protege, até mesmo com força policial. ${ }^{116}$

O Estado passa assim a dar seu apoio e a declarar a sua fé a uma religião

\footnotetext{
${ }^{110}$ SORIANO, A., 2002, p. 77

${ }^{111}$ LANARES, 1964, p. 202

${ }^{112}$ MACHADO, 1996, p. 305

113 SILVA, 2010, p. 250.

${ }_{114}^{114}$ COLLIARD, 1979, p. 331.

115 ROBERT, 1993, p. 509.

${ }^{116}$ FERREIRA FILHO, Religião, Estado..., 2002, p. 81-89.
} 
determinada, reservando aos seus representantes uma parcela de autoridade que poderá ser objeto de profundos conflitos. ${ }^{117}$

A proteção do Estado a uma ou mais religiões é uma forma atenuada do sistema de confusão. O Estado não se confunde com uma Igreja, mas lhe concede uma proteção especial. O Estado passa a ter o poder de negar ou reconhecer privilégios a uma religião, o que gera a possibilidade de discriminação entre os direitos dos fiéis de religiões não reconhecidas. ${ }^{118}$

$\mathrm{Na}$ época do Império, o Brasil era considerado um Estado confessional, pois a religião católica apostólica romana era a religião oficial do Império e todas as outras eram apenas toleradas pelo Estado. ${ }^{119}$

Costuma-se atribuir a estes modelos em que há uma confusão ou subordinação da Igreja com o Estado a origem da intolerância religiosa. De fato, analisando-se os exemplos históricos, a união entre a Igreja e o Estado foi a grande responsável por episódios de restrição à liberdade religiosa e pelo surgimento de doutrinas profundamente intolerantes, a exemplo do que ocorreu com as inquisições portuguesa, espanhola e italiana.

O reconhecimento de uma religião oficial pelo Estado é mais receptivo à existência da tolerância religiosa do que o regime teocrático que, de um modo geral, não se baseia no reconhecimento da liberdade religiosa. ${ }^{120}$

Não há, contudo, impossibilidade teórica de que em um Estado que reconheça uma religião como oficial seja plenamente garantida a liberdade religiosa. Basta que para isso o Estado tolere as demais religiões sem embaraçar-lhes o funcionamento. É verdade que o reconhecimento de uma religião pelo Estado propicia o surgimento de movimentos persecutórios contra as demais religiões que não ostentam o apoio estatal.

A Constituição Espanhola trata igualmente todas as religiões, contudo, faz expressa menção à Igreja Católica. Pode-se pensar numa maior proteção do Estado a tal religião sem que com isso se possa inferir que a Espanha desrespeite a liberdade e a tolerância religiosas. ${ }^{121}$

O confessionalismo ou não confessionalismo estatal não pode ser um medidor da liberdade religiosa dos cidadãos de um país. Tanto é possível um Estado

\footnotetext{
${ }^{117}$ RIVERO; MOUTOUH, 2006, p. 526.

${ }^{118}$ LANARES, 1964, p. 202-3.

${ }^{119}$ CRETELLA JR, 1974 p. 105.

${ }^{120}$ SORIANO, A., 2002, p. 7.9-80

${ }^{121}$ GONZALEZ, 1997, p. 145.
} 
confessional com liberdade religiosa plena, tal como é o caso dos Estados nórdicos europeus, como um Estado não confessional com uma clara hostilidade ao fato religioso, conduzente a uma extrema precariedade da liberdade religiosa, como foi o exemplo da Segunda República espanhola. ${ }^{122}$

Não necessariamente a laicidade estatal significa garantia de plena liberdade religiosa, uma vez que exageros cometidos pelo Estado para garantir e impor a laicidade aos cidadãos pode gerar severas ameaças ao exercício da liberdade religiosa dos indivíduos. A aplicação extremista de qualquer princípio, seja o da laicidade, seja o do confessionalismo pode gerar restrições indevidas às liberdades dos cidadãos.

Tratando-se, ainda, de modelos de separação entre Estado e Igreja é necessário fazer referência às Constituições dos países da antiga União Soviética, que mencionavam expressamente o ateísmo. ${ }^{123}$ Não se trata aqui de não reconhecer nenhuma religião como oficial, mas sim de hostilizar a existência de religiões. Trata-se de uma intolerância à qualquer tipo de religião.

Por fim, há o modelo de separação entre Igreja e Estado, adotado pela Constituição Federal de 1988, que por isso merecerá um tópico em apartado.

\section{II.2- Separação entre Estado e Igreja}

\section{II.2.1- Histórico}

A ideia de separação entre Estado e Igreja surgiu com a quebra da unidade político-religiosa da cristandade e com as guerras religiosas. O surgimento de novas religiões faz com que comecem a ser pensados documentos que assegurem a coexistência pacífica entre as religiões. São expoentes desta nova concepção a Paz de Augusta (1555) e a Paz de Vestfália (1614) que antes de pretender separar a Igreja do Estado pretenderam garantir um ambiente de tolerância e paridade entre as religiões, de modo a evitar conflitos.

A concepção que hoje é consagrada de liberdade religiosa e de separação entre a Igreja e Estado teve seu início, predominantemente, graças às minorias religiosas e muito pouco em razão das religiões dominantes. Estas contribuíram com a ideia de liberdade religiosa, num momento inicial, quando lutaram para ter liberdade face às pretensões totalitárias do poder político estatal.

Foram, contudo, as minorias religiosas as principais responsáveis pelos

\footnotetext{
122 SORIANO, R., 1990, p. 84.

${ }^{123}$ GONZALEZ, 1997, p. 149.
} 
maiores avanços na luta pela liberdade religiosa. Grupos religiosos, que remontam à época da Reforma, tais como os Anabatistas, os Batistas e os Quackers foram bastante importantes no reconhecimento de uma nova concepção sobre a religião. ${ }^{124}$

Muito da concepção que hoje se tem de separação entre Igreja e Estado advém da Revolução Francesa de 1789, que apesar de não ter tratado especificamente da laicidade deixou uma herança em matéria de direitos humanos que levou à teoria que hoje é conhecida.

A Constituição civil do clero em 1790 revela uma vontade em submeter a religião ao estatuto civil. Em 1795, o Diretório separou a Igreja do Estado através da lei de 3 Ventôse. A ideia existente de laicidade surge no período revolucionário como uma reação ao absolutismo francês. A religião é relegada a uma posição secundária.

A Constituição de 1795 reformula esta separação até que a Concordata assinada entre Napoleão e a Santa Sé permite o restabelecimento do culto católico como religião do Estado.

A laicidade, contudo, surge definitivamente no cenário francês oficialmente com a Lei de 1905. A laicidade é colocada no centro dos problemas políticos, sociais e jurídicos contemporâneos. O debate leva em consideração principalmente a religião islâmica, cuja presença cresceu na França com a chegada de imigrantes após a II Guerra Mundial.

Com a $3^{a}$ República, a laicidade passa a ser vista como uma forma de garantir o exercício dos cultos e a liberdade religiosa. A neutralidade passiva do Estado advinda da Lei de 1905 transformou-se numa concepção mais ativa para criar condições concretas para a garantia da liberdade religiosa.

A partir dos anos 60, a leitura do princípio da laicidade traz a existência de duas obrigações: a proibição de intervir nos assuntos religiosos e a obrigação de conciliar as diferentes religiões para garantir efetivamente a liberdade religiosa. ${ }^{125}$

\footnotetext{
${ }^{124}$ MACHADO, Jonatas Eduardo Mendes, A Constituição e os movimentos religiosos minoritários. Boletim da Faculdade de Direito da Universidade de Coimbra, Coimbra. n.72. 1996, p. 213-5.

${ }^{125}$ DELSENNE, Ludivine, De la difficile adaptation du principe républicain de laïcité à L'évolution socioculturelle française. Revue du Droit Public et de la Science Politique en France et à L'Etranger Paris. mars/avr. n.2, 2005, p. 428-450.
} 


\section{II.2.2- Laicidade: conceito}

Pelo modelo da separação, o Estado toma uma posição de indiferença com relação às religiões, deixando tanto de favorecê-las quanto de contrariá-las. ${ }^{126} \mathrm{O}$ Estado, assim, assegura a liberdade de culto, mas recusa a intervenção em qualquer tipo de igreja.

Há total independência entre a religião e o Estado, de tal modo que um não pode interferir no domínio do outro. A separação pode significar ou uma ignorância total do fato religioso pelo Estado ou ainda uma hostilidade em relação às religiões, de modo a substituir uma religião oficial por uma doutrina puramente materialista. ${ }^{127}$

São elementos característicos da laicidade estatal a autonomia e a independência da autoridade civil no confronto com a autoridade religiosa, nãoconfessionalidade do Estado e a sua neutralidade e imparcialidade em matéria religiosa.

Estes elementos traduzem o instituto jurídico e mudam de ordenamento para ordenamento e de período para período da história, afinal a laicidade antes de ser uma realidade jurídica é um princípio político e, portanto, um valor relativo, historicamente determinado. Não há um modelo universal de separação Estado e Igreja para todos os Estados. $^{128}$

Robert $^{129}$ entende alguns pontos como fundamentais na caracterização de um Estado laico. Em primeiro lugar, há o não reconhecimento de culto. Tal vedação significa que o Estado não pode reconhecer oficialmente um culto, o que não significa dizer que o Estado deva desconhecer a existência das religiões. Apenas pretende-se dizer que o sistema de religiões reconhecidas foi abandonado.

Em segundo lugar, há a não-subvenção das religiões pelo Estado, que significa precipuamente a supressão do serviço público da Igreja. Admite-se, contudo, a possibilidade de o Estado subvencionar as atividades que apresentem um caráter geral e que sejam exercidas sobre uma estrutura confessional; a contratação direta pelas coletividades públicas de certos serviços religiosos; a remuneração de ministros de culto quando prestem serviços às pessoas públicas.

No que diz respeito à impossibilidade de o Estado subvencionar cultos ou religiões, Colliard ${ }^{130}$ entende que surge um problema complicado. Afinal, a verdadeira

\footnotetext{
${ }^{126}$ COLLIARD, 1979, p. 331.

${ }^{127}$ RIVERO; MOUTOUH, 2006, p. 526

${ }^{128}$ OLIVITO, Elisa. Laicità e simboli religiosi nella sfera pubblica esperienze a confronto. Diritto Pubblico,

Bologna, v.10, n.2, mag./ago. 2004, p. 549-550.

${ }^{129}$ ROBERT, 1993 p. $514-517$.

${ }^{130}$ COLLIARD, 1979 , p. 344
} 
proibição seria à subvenção direta inscrita em um orçamento para beneficiar uma Igreja ou seus membros. Seria preciso ter bastante cautela para que a existência do Estado laico não significasse um embaraço à liberdade religiosa. O princípio da laicidade deve ter um caráter relativo, de modo a admitir alguns limites que facilitem o exercício de diferentes cultos.

Aqui remonta-se à ideia outrora esboçada de que a laicidade pode, ao invés de significar plena garantia à liberdade religiosa, resultar em tratamento hostil às religiões, que acabarão sendo vistas como algo a ser proscrito pelo Estado. No decorrer deste trabalho, esta ideia será desenvolvida na análise de casos concretos.

Dentro da teoria da separação, pode-se pensar em dois modelos possíveis. O primeiro é o da tolerância. Por esse subsistema, o Estado leva em consideração os fatos religiosos e a existência das religiões, no entanto não se intromete em seus negócios. Há, assim, uma adaptação do Estado em função da realidade. No segundo subsistema, o Estado além de não se imiscuir nos assuntos das igrejas e das religiões, vai mais adiante e age de modo a ignorar total e deliberadamente uma religião. ${ }^{131}$

Na ideia de separação, há, por um lado, a necessidade de as religiões não estarem submetidas à tutela estatal e, por outro, a vontade de o Estado e de os indivíduos não estarem sujeitos à pressão religiosa. Deste binômio, surgem os seguintes preceitos: o indivíduo não deve prestar contas de sua crença ao Estado; o Estatuto da Igreja se assemelha a de sociedades de direito privado; a Igreja pode se administrar pelo direito comum; a Igreja é responsável por seus fiéis e; as relações entre Estado e Igreja reduzemse a menor possível. ${ }^{132}$

Deixa, assim, de existir um estatuto privilegiado de cultos reconhecidos, não podendo haver estabelecimentos públicos que assegurem o exercício efetivo dos cultos, os ministros de cultos não são agentes públicos e não há destinação de dinheiro público às confissões religiosas.

Se a Igreja perde os seus privilégios, o Estado devolve-lhe a plena liberdade, renunciando a todos os direitos que o Estado detinha sobre a organização das Igrejas. Os únicos limites que permanecem existindo à liberdade de culto são aqueles impostos a todos, ou seja, o respeito à ordem pública. ${ }^{133}$

\footnotetext{
${ }^{131}$ ROBERT, 1993 p. 509.

${ }^{132}$ LANARES, 1964, p. 203-4.

${ }^{133}$ RIVERO; MOUTOUH, 2006, p. 541-2.
} 
A laicidade do Estado implica enxergar a religião como um assunto privado, sem intervenção estatal. No modelo de separação, convergem os institutos da liberdade religiosa, da laicidade e da neutralidade. A afirmação de não ingerência total do Estado no fenômeno religioso não é totalmente verdadeira, a começar pela perspectiva da liberdade religiosa, em que o Estado é praticamente obrigado a conviver com o fenômeno religioso. $^{134}$

O conceito de laicidade não é unívoco. Para alguns, ele consiste numa interpretação estrita e negativa, significando a não intervenção do Estado no domínio religioso, ao mesmo tempo que a submissão das atividades religiosas à ordem pública estatal. Surge como decorrência da laicidade do Estado a igualdade entre os cultos, inerente à liberdade religiosa. Em tal acepção, a laicidade é sinônimo de neutralidade do Estado. Ou, por outro modo, a neutralidade do Estado seria a ausência de confessionalidade.

Para outros, a laicidade não poderia ignorar o fato religioso, realizando uma verdadeira diferenciação entre as religiões em função do seu impacto sobre a sociedade política nacional. ${ }^{135}$

Da separação entre Estado e Igreja, decorrem alguns princípios que a fundamentam, tais como, a indiferença ou a neutralidade confessional do Estado e a liberdade de organização e independência das igrejas e confissões religiosas.

A indiferença ou neutralidade confessional do Estado impede que haja qualquer ingerência religiosa no Estado ou nos poderes públicos. Dessa maneira, as autoridades públicas não podem desempenhar funções religiosas, tornando-se ilegítima a realização de cerimônias religiosas oficiais. Ainda de acordo com Canotilho e Vital Moreira, a neutralidade estatal impede que haja qualquer relação entre atos, funções e locais estatais e símbolos e ritos religiosos.

O segundo princípio seria o da não ingerência do Estado na organização das igrejas e no exercício de suas funções e do culto. A regra é a não intervenção do Estado na organização das Igrejas, mas poderá o Estado intervir nestas áreas através da regulamentação normativa da liberdade de organização e associação privada e o direito de reunião e de manifestação. ${ }^{136}$

\footnotetext{
${ }^{134}$ DRAGO, Roland. Laicité, neutralité, liberté? Archives de Philosophie du Droit, Paris, n. 38, 1993, p. 222-4.

${ }^{135}$ PIERRE CAPS, 1990, p. 1076-7.

${ }^{136}$ CANOTLIHO; MOREIRA, 1993, p. 244.
} 
Como acontece na conceituação de diversas liberdades, também para o princípio da separação entre Estado e Igreja reconhece-se um aspecto negativo e um positivo.

O aspecto negativo da religião prega uma separação completa entre o Estado e a questão religiosa. O fato religioso passa a ser totalmente estranho ao Estado, tornandose um assunto puramente privado. A questão religiosa torna-se o exercício de uma liberdade reconhecida aos cidadãos.

Tal aspecto negativo começa a perder razão, já que o Estado mantém relações com os demais assuntos privados (manifestações sociais, culturais, econômicas), com exceção dos assuntos religiosos. ${ }^{137}$ Neste caso, o Estado se considera totalmente incompetente no domínio religioso, recusando-se a qualquer tipo de intervenção. ${ }^{138}$

Começa-se a vislumbrar, portanto, o aspecto positivo da laicidade, em que o Estado não apenas a respeita, mas assume o compromisso de garantir a sua obediência. ${ }^{139}$

A proibição do Estado em qualificar as crenças religiosas não significa que as autoridades devam ficar ausentes ante o comportamento dos cultos. Pelo contrário, elas devem agir para impedir que haja um desrespeito à lei. A garantia do interesse público poderá justificar uma intervenção estatal no fenômeno religioso, desde que haja proporcionalidade na medida.

Assim, a necessidade de garantir o respeito a direitos fundamentais pode vir a justificar uma intervenção estatal, que deverá, contudo, ter um caráter pontual, em atos determinados, devendo respeitar os direitos dos grupos religiosos. Para o Estado não importa a qualificação do grupo religioso, se religião tradicional, se seita, o que importa para o Estado é que as consequências dos atos religiosos acabem ferindo direitos alheios a justificar a proteção estatal.

A depender do ato praticado pelos grupos religiosos, a intervenção estatal pode recair inclusive sobre atos de crença que sistematicamente violem a lei. ${ }^{140}$

$\mathrm{O}$ aspecto positivo, entretanto, impõe ao Estado que ele trate todas as religiões de maneira igual, sem qualquer tipo de discriminação. Esta perspectiva representa um avanço da laicidade, na medida em que ela passou a se relacionar com a liberdade religiosa, dando-lhe prevalência. ${ }^{141}$

\footnotetext{
${ }^{137}$ BELLANGER, 2000, p. 33.

${ }^{138}$ GONZALEZ, 1997, p. 151.

${ }^{139}$ RIVERO; MOUTOUH, 2006.

${ }^{140}$ BELLANGER, 2000, p. 33-6.

${ }^{141}$ GONZALEZ, Op. cit., p. 151-2.
} 
A partir do momento em que a liberdade religiosa começou a ser reconhecida como parte do princípio da separação entre Estado e Igreja, deixou-se de esperar que o Estado tivesse uma neutralidade axiológica pura. “Os poderes públicos estão vinculados, designadamente, aos valores fundamentais, constitucionalmente consagrados, da dignidade da pessoa humana e do tratamento de todos os cidadãos como livres e iguais, membros de pleno direito da comunidade política." 142

A neutralidade do Estado não significa que o fenômeno religioso ou uma religião em particular devam ser hostilizados pelos poderes públicos. A neutralidade tem como finalidade evitar a coerção e a discriminação em âmbito religioso, garantindo a liberdade e a igualdade jurídica entre todos os cidadãos. ${ }^{143}$

A laicidade enquanto neutralidade pura representa uma ilusão de que a autoridade administrativa, o juiz ou o legislador terão somente uma atividade de abstenção. A religião, contudo, é um fato social e o Estado, enquanto instrumento regulador da vida social, não pode deixar de se relacionar com o fato social. ${ }^{144}$

Tem-se, inclusive, vislumbrado uma tendência em estatizar a religião, para que ela volte a ocupar espaço na esfera pública. O risco deste pensamento é dar maior prevalência a valores que representam a maioria da sociedade, mas não a sua unanimidade, acabando por discriminar as religiões minoritárias. ${ }^{145}$

A ideia de que a laicidade do Estado pode admitir algumas restrições para que seja garantida a liberdade religiosa confere ao Estado além de um comportamento negativo quanto às religiões, também um comportamento positivo. A conduta negativa diz respeito à já citada impossibilidade de subvencionar uma religião ou de adotar uma religião oficial.

Quanto às atitudes positivas do Estado, podem ser apontadas: a tipificação de atos que agridam uma religião como crime; a assistência religiosa; o ensino religioso em escolas públicas. Salientemos que, nesses últimos casos, o Estado funciona apenas como regulador do exercício da liberdade religiosa e sua atividade é feita sem qualquer ônus para os cofres públicos. ${ }^{146}$

Neste sentido, a ausência de caráter público dos cultos não proíbe o Estado de manter relações de cortesia com seus representantes, como com as outras autoridades

\footnotetext{
142 MACHADO, A Constituição e os movimentos.... 1996, p. 228.

${ }^{143}$ MACHADO, Op. cit., 1996, p.231.

${ }^{144}$ PIERRE CAPS, 1990, p. 1091.

145 OLIVITO, 2004, p. 551-3.

${ }^{146}$ FERRAZ, 1997, p. 22-23.
} 
privadas. A proibição de manter relações com o Estado não se estende às atividades que, embora organizadas num âmbito confessional, apresentam por si só um caráter de interesse geral. Os serviços cultuais prestados às entidades públicas por ministros dos cultos podem ser remunerados. Mesmo uma atividade propriamente cultual, quando é exercida a pedido de uma entidade pública, pode ser objeto de uma remuneração. ${ }^{147}$

Tratando-se, ainda, de conceito de laicidade, há quem realize uma diferença de definições entre laicidade e laicismo. A laicidade teria como principal característica uma atitude neutra do Estado, respeitadora das manifestações religiosas, sem qualquer tipo de intervenção. Já o laicismo seria uma verdadeira filosofia ou ideologia, nascida no republicanismo europeu, que teria como intuito realizar um corte com os modelos de unidade político-religiosos do antigo regime. Seria necessário destruir todas as estruturas de domínio existentes para substituí-las por estruturas emancipatórias.

O pensamento laicista trouxe um viés de profunda hostilidade às religiões, promovendo o seu afastamento da esfera pública, além da disseminação de uma mentalidade indiferente às religiões.

Começam, porém, a ser rejeitados, historicamente, os modelos de profunda hostilidade à religião, a exemplo do que ocorreu com os modelos comunista e nacional socialista. O regime comunista enxergava a religião como o ópio do povo, no sentido de uma estrutura montada pela burguesia para afastar a classe proletária dos problemas econômicos verdadeiros. A religião teria uma função política de mistificação e conservação das desigualdades sociais.

Por outro lado, o nacional-socialismo buscou fundamento numa teologia política de origem judaico-cristã para misturar imperativos divinos com ideias nacionalistas e de pureza étnica. As pretensões do III Reich com o tempo passaram a colidir com as proposições religiosas, de modo que o fortalecimento do Estado somente ocorreria com o enfraquecimento da Igreja. ${ }^{148}$

O surgimento de novas religiões em Estados que, tradicionalmente, estavam acostumados a conviver com apenas uma religião causou novos desafios ao papel laico do Estado.

Exemplo clássico é o surgimento do islamismo na França. A integração dos praticantes do islã na sociedade francesa somente será possível a partir do momento em que o Estado tiver a mesma tolerância que apresenta para as demais religiões com a

\footnotetext{
${ }^{147}$ RIVERO; MOUTOUH, 2006, p. 543-4.

${ }^{148}$ MACHADO, Liberdade religiosa numa comunidade..., 1996, p. 306-309.
} 
religião islâmica. Obviamente que o Islã é beneficiado por algumas liberdades essenciais na França, como liberdade de associação, direitos aos feriados tradicionais, mas ainda o Estado francês não consegue lidar com os novos desafios que surgem com a nova religião na sociedade. ${ }^{149}$

Segundo François Bellanger ${ }^{150}$, nos países em que há uma ou no máximo duas religiões que congregam a maioria da população dificilmente haverá conflitos religiosos. Contudo, nos lugares em que as religiões tradicionais perderam lugar, o sistema passa a apresentar complicações.

O Estado tem empreendido lutas ferrenhas contra estas novas seitas. Para enfrentar este problema, haveria dois caminhos possíveis. O primeiro seria reconhecer as novas religiões, ao lado das tradicionais, para lhes conferir um estatuto particular. Este modelo foi adotado pela Itália e pela Bélgica. Agora, se o Estado começar a reconhecer religiões, ele poderá apresentar arrependimento? Ademais, como preceitua o autor, o Estado não pode reconhecer uma religião em detrimento de outra, pois ele não tem padrões adequados para realizar tal distinção.

O segundo caminho é entender que o campo religioso é um campo liberado. O Estado não reconhece nem apoia qualquer religião. A atividade estatal apenas cuida para que não sejam feridos direitos dos cidadãos. A intervenção estatal é bastante impessoal para proteger os direitos individuais contra pessoas ou organizações que descumpram a lei.

Além da introdução de religiões tradicionais em países que estavam acostumados a apenas uma ou duas religiões, como é o caso da França, verifica-se o surgimento de verdadeiras novas religiões. Eis a discussão da existência de seitas e de religiões.

Há quem vislumbre ${ }^{151}$ um certo receio na doutrina constitucional em utilizar a palavra seita para designar os novos movimentos religiosos. Esta expressão teria uma conotação preconceituosa, utilizada de uma forma pejorativa, podendo ser conduzida à categoria do hate speech ou fighting words.

O termo seita teria, assim, uma conotação negativa, pois denotaria uma relação de superioridade das religiões tradicionais. Ademais, esta expressão pode ter um sentido equivocado, pois um movimento religioso que não tenha grande expressão em um

\footnotetext{
${ }^{149}$ RIVERO; MOUTOUH, 2006, p. 533

${ }^{150}$ BELLANGER, 2000, p. 38-9.

${ }^{151}$ MACHADO, A Constituição e os movimentos..., 1996, p. 217-221.
} 
lugar, pode ser bastante tradicional em outro. Além disso, não se pode esquecer que todas as religiões tradicionais começaram como meras seitas.

No tratamento das novas religiões, é importante lembrar que a Constituição não se baseia apenas no princípio democrático, no sentido de prevalência dos direitos da maioria. Os direitos fundamentais, o Estado de Direito e a Separação dos Poderes garantem não apenas a proteção à concepção majoritária, mas principalmente a necessidade de a opinião da maioria respeitar os interesses de todo um povo.

$\mathrm{Na}$ relação entre Estado e Igreja não adianta apenas cuidar e das religiões majoritárias, mas sim todas as expressões religiosas por menos expressivas que elas sejam.

A dificuldade de se manter um Estado constitucional reside exatamente em garantir os direitos das minorias frente à opinião majoritária discordante. Por óbvio que o Estado tem valores fundamentais, cujo descumprimento não pode ser aceito sob o manto constitucional e democrático. Estando, contudo, os direitos das minorias de acordo com os valores constitucionais devem eles ser igualmente, ou talvez mais intensamente, protegidos inclusive contra eventuais opressões da maioria. Defender valores que a maioria dos cidadãos acredita não representa desafio a um Estado. Por outro lado, a defesa igualitária de valores não compartilhados pela maioria dos indivíduos testa a verdadeira vocação democrática de respeito aos direitos fundamentais do Estado.

\section{II.2.3- Modelo americano de laicidade}

Nos EUA, a liberdade religiosa está prevista na $1^{\mathrm{a}}$ Emenda à Constituição americana. A cláusula que prevê a separação entre Estado e Igreja, conhecida como establishment clause, impõe a limitação do poder estatal para permitir o desenvolvimento de movimentos religiosos.

Por uma interpretação histórica, a cláusula de separação proíbe que seja criada uma Igreja Nacional, isto é, uma religião com apoio estatal que seria hierarquicamente superior às demais. Por outro lado, adotando-se uma interpretação restritiva, poder-se-ia pensar na possibilidade de o Estado praticar qualquer ato religioso, desde que os cidadãos pudessem se escusar de sua prática. ${ }^{152}$

O primeiro desafio enfrentado pelo constitucionalismo foi inserir no quadro da separação a maior importância que passou a ser dada ao direito à liberdade religiosa. A

${ }^{152}$ BROWNSTEIN, Alan, La proteccion otorgada por la Constitucion de los Estados Unidos a las crencias religiosas y a los grupos religiosos. Revista de la Facultad de Derecho de Mexico. Mexico, v. 41, n. 178179-180, 1991, p. 15-7. 
partir de então a preocupação era proteger a liberdade religiosa das restrições impostas pelo Estado. ${ }^{153}$

A Corte Suprema dos EUA apresenta primeiramente uma interpretação bastante estreita da cláusula de Separação entre Estado e Religião, chegando inclusive a usar a metáfora de que existiria um muro entre o Estado e a Igreja. Em Lemon v. Kurtzman, a Corte entendeu que qualquer intervenção estatal seria indevida se não tivesse nenhum motivo ou propósito secular. Se tivesse como efeito principal a promoção de uma religião em geral ou de alguma crença em particular ou se implicasse uma inter-relação excessiva entre instituições e atividades religiosas do Estado, a intervenção seria indevida. ${ }^{154}$

De acordo com os critérios propostos, um ato dos poderes públicos não será inconstitucional pelo simples fato de prestar algum auxílio à religião. A inconstitucionalidade só se verificará, em princípio, 1) se o ato não tiver um propósito secular, 2) se o seu efeito primário for a promoção ou a inibição da religião, ou 3) se provocar um envolvimento excessivo entre os poderes públicos e a religião. ${ }^{155}$

A ideia de separação foi aplicada com bastante frequência e rigor no ambiente escolar. Têm sido admitidas algumas aberturas, tais como a concessão de benefícios governamentais (gratuidade do transporte público, empréstimo de livros laicos a escolas religiosas) e o respeito a dias religiosos e eventos cerimoniais de tradição e origem históricas. O reconhecimento de feriados e dias religiosos foi visto pela Corte com uma certa restrição. $\mathrm{O}$ fechamento dos estabelecimentos comerciais aos domingos, apesar de ter um motivo religioso, acaba beneficiando todos os cidadãos, por isso seria admitido.

Outra exceção à Separação é a norma constitucional compensatória do livre exercício. A Separação não é violada se o Estado der tratamento preferencial a um grupo ou instituição religiosos, por estar obrigado por outro mandamento constitucional independente e de igual importância. É o caso em que o livre exercício da religião de um indivíduo choca-se com a liberdade de outro. Como somente um irá prevalecer, poder-se-ia dizer que uma religião foi beneficiada pelo Estado, quando na verdade há apenas a solução de um conflito entre direitos. ${ }^{156}$

De extrema importância para a definição dos limites da laicidade, nos EUA, é o caso Smith em que a Suprema Corte escolheu deixar a regulamentação da religião para

\footnotetext{
${ }^{153}$ MACHADO, Liberdade religiosa numa comunidade..., 1996, p. 311-3

${ }^{154}$ BROWNSTEIN, Op. cit., p. 17.

${ }^{155}$ MACHADO, Liberdade religiosa ...., 1996, p. 315

${ }^{156}$ BROWNSTEIN, 1991, p. 18-21.
} 
o processo político, dando enormes vantagens às religiões tradicionais que teriam mais chances de ter suas crenças e tradições contempladas em leis. ${ }^{157}$

A Suprema Corte rejeitou a alegação da parte de que o uso da maconha poderia ser permitida excepcionalmente por motivos religiosos. O Estado não tem nenhum dever de escusar pessoas cuja religião seja substancialmente oprimida pelo resultado de uma lei de aplicação geral e neutra. Justice Scalia coloca a preocupação de que se a lei dotada de generalidade e neutralidade não for aplicada igualmente para todos, haverá algo reconhecidamente superior à lei, tal como a fé religiosa. E isso é algo que uma Nação fundada no Estado de Direito não pode aceitar. ${ }^{158}$

Vislumbra-se que o desfavorecimento de confissões religiosas torna-se inevitável num Estado de Direito, uma vez que o papel das religiões fica dependente do processo político democrático. ${ }^{159}$

Smith fez com que a liberdade religiosa deixasse de ser uma liberdade substancial para ser um direito comparativo, em que o tratamento requerido constitucionalmente das práticas religiosas depende do tratamento dado comparativamente às práticas seculares. ${ }^{160}$

Após Smith, qualquer pessoa que tenha sua liberdade religiosa ferida por uma lei geral e neutra não tem nenhum recurso a não ser confiar no processo policial ou procurar uma exceção na legislação estadual. A regra do caso Smith fará com que as religiões menores sejam mais agredidas que as majoritárias, afinal estas terão mais poder para fazer com que leis benéficas a elas sejam aprovadas nos Estados.

Após Smith, ganha relevância a decisão em Wisconsin v. Yoder, em que se decidiu que pais Amish não poderiam ser obrigados a mandar seus filhos para a escola até o $8^{\circ}$ grau em escolas públicas, pois isso feriria o livre exercício de culto deles. Justice Scalia entende que, neste caso e em outros em que a Corte se manifestou, deveriam ser concedidas exceções em relação a leis de caráter geral e neutro, pois se tratariam de situações híbridas. A Corte, contudo, não consegue demonstrar qual a diferença entre o caso Yoder e o caso Smith, já que neste a Corte não permite nenhum tipo de exceção a leis gerais. Parece que a Corte se recusou a dar uma definição precisa do que seria o conceito

\footnotetext{
${ }^{157}$ LAYCOCK, Douglas. Theology scholarships, the pledge of allegiance and religious liberty: avoiding the extremes but missing the liberty. Harvard Law Review, Cambridge, v.118, n.1, 2004, p. 202

${ }^{158}$ NEUTRAL rules of general applicability: incidental burdens on religion, speech and property. Harvard

Law Review, Cambridge, v.115, n.6, apr. 2002, p. 1721-2.

${ }^{159}$ MACHADO, Liberdade religiosa ..., 1996, p. 313.

${ }^{160}$ LAYCOCK, 2004, p. 202
} 
de neutralidade. ${ }^{161}$

Laycock Douglas ${ }^{162}$ cita mais alguns casos que definiram o posicionamento da Corte sobre a separação do Estado e da Igreja. Em Church of the Lukumi Babalu Aye Inc. v. City of Hialeah, discutiu-se a existência de leis locais que proibiam o sacrifício de animais, definindo morte, tortura, mutilação desnecessários de um animal em ritual ou cerimônia público ou privado que não destinado à alimentação. A prefeitura argumentava que era um banimento geral. A igreja argumentava que era um banimento para matar animais por razões religiosas, criada minuciosamente para não proibir a morte de animais por razões seculares. A Corte unanimemente concordou com a Igreja.

A exigência da neutralidade proíbe qualquer ação oficial que mire a conduta religiosa para um tratamento distinto ou leis cujo objeto seja suprimir a prática religiosa.

Segundo o autor, Smith falava apenas em exceções individualizadas, mas Lukumi também confiou nas exceções genéricas. A Corte entendeu que a lei não era de aplicabilidade geral, pois excepcionava categorias inteiras. Obviamente que toda lei tem uma categoria como objeto, mas quando a lei é destinada a criar uma discriminação religiosa, ela não pode ser considerada de aplicabilidade geral.

Em Fraternal Order of Police v. City of Newark, debate-se a regra de que os policiais deveriam sempre estar com a barba feita, salvo por razões médicas e para a criação de disfarces. Não havia qualquer exceção, contudo, à religião. A lei fez uma escolha em que as razões médicas eram mais importantes que razões religiosas.

Havendo um tratamento legal desigual a práticas seculares e religiosas, impondo-se uma agressão à religião, deve ser empregado o teste do compelling interest. Pretende-se, assim, buscar a existência de um motivo injusto na decisão do Estado de criar situações desiguais. Não havendo uma razão desarrazoada para a desigualdade, ela deve permanecer válida.

Em Davey, discute a Corte a constitucionalidade das políticas públicas de Washington, que aparentemente seriam neutras em relação às religiões. A Corte aceita a existência de uma discriminação aparente, mas determina que a inconstitucionalidade somente existiria se houvesse uma agressão a uma prática religiosa.

Entender-se-ia que uma lei seria inconstitucional se ela impusesse penalidades civis ou criminais ou se exigisse a renúncia a direitos políticos. Esses motivos

\footnotetext{
${ }^{161}$ NEUTRAL RULES, 2002, p. 1723-4.

${ }^{162}$ LAYCOCK, 2004, p. 206-220.
} 
são alternativos, não havendo necessidade de ambos serem provados.

Presume-se uma lei inconstitucional caso imponha penalidade, restrinja a participação política ou force a escolha entre a prática religiosa e outros benefícios governamentais. Justice Scalia sugere uma quarta forma de identificar uma agressão à religião que diz respeito ao financiamento das religiões. A Corte entende que o não financiamento estatal do clero não é uma agressão à religião, pois esta atitude governamental é quase uma tradição.

A Corte conclui que a negativa de financiar ensino religioso vocacional não é por si só inconstitucional. O motivo antirreligioso é uma quarta razão para encontrar uma possível inconstitucionalidade.

Tratando de discurso religioso, a Corte define que uma pessoa expondo em nome próprio as suas convicções religiosas não pode ter sua liberdade obstada pelo Estado. O discurso religioso somente poderia ser atribuído ao governo, caso ele concedesse privilégios de maneira desigual a discursos seculares e religiosos.

A Corte reconhece algumas exceções para o discurso religioso, como a possibilidade de abrir a sessão legislativa com uma prece e a veiculação de um programa municipal de Natal que incluía Papai Noel, cenas da Natividade.

Se o governo não endossou o discurso religioso, ele deve ser considerado particular e constitucionalmente protegido, não importando o lugar em que foi proferido, até mesmo em propriedade do governo ou em escola pública. Se uma pessoa faz um discurso religioso e os servidores do governo não expressam nenhuma opinião sobre a mensagem, não convidam para a palestra, não dão ao palestrante nenhum benefício especial se, em suma, eles tratam o palestrante religioso da mesma forma que um particular, o discurso religioso é atribuído exclusivamente ao particular. Esta regra vale em escolas públicas, universidades ou outras propriedades do governo.

Jonatas Eduardo Mendes Machado ${ }^{163}$ cita alguns outros julgados que ganharam importância para determinar testes a fim de verificar se a discriminação religiosa seria ou não permitida. O endorsement test foi desenvolvido pela Juíza O'Connor em Lynch $v$. Donnely e tem como intuito analisar a mensagem que o apoio estatal a uma religião específica envia aos seus fiéis e aos demais cidadãos.

Há também o coercion test, criado pelo Juiz Kennedy em Allegheny County v. $A C L U$, em que se discutia a possibilidade de exposição de um presépio nas escadas

\footnotetext{
${ }^{163}$ MACHADO, Liberdade religiosa..., 1996, p. 318-9
} 
principais do Tribunal do Condado de Allegheny. A Corte decide pela inconstitucionalidade da participação dos poderes públicos, uma vez que o presépio tem claro motivo religioso. Justice Kennedy fala da possibilidade de existir diversas formas de coação, sejam elas sutis ou ostensivas, ligadas à atuação estatal em movimentos religiosos. No caso debatido, o Juiz não vê qualquer violação à establishmente clause, uma vez que ainda que o apoio estatal ao presépio passe ao público uma mensagem simbólica, não se poderia pensar numa coerção estatal que daí decorresse. Desta maneira, não haveria que se impedir a exibição do presépio.

Ronald Dworkin ${ }^{164}$ enxerga na política norte-americana uma tendência de crescimento da influência da religião sobre a política. Questiona o autor se concepções religiosas podem servir como base argumentativa para a definição de temas importantes para a sociedade, tais como, aborto, pesquisa com células-tronco e casamento gay. Poderia o governo se valer de tais argumentos, se nem todos os cidadãos americanos acreditam em Deus e mesmo entre os que acreditam não há uma convergência de ideias?

Para enfrentar o problema religioso, o autor relembra dois modelos possíveis de relação entre Estado e Igreja. O primeiro corresponderia a um Estado religioso que, contudo, tolerasse quem não acredita na religião estatal. O segundo seria o Estado secular que toleraria os religiosos. Para o autor, os EUA atualmente adotam uma parcela dos dois modelos.

Israel adota como religião oficial o Judaísmo, mas prega a liberdade de religião, já a França, pelo contrário, é um Estado secular.

Um estado religioso, ainda que não tenha uma religião oficial, defende a religião como algo importante para o bem da sociedade e das pessoas. Assim, não apresenta qualquer problema em fazer referência a um deus único em seus juramentos e pronunciamentos oficiais. Ele garante respeito a todos os tipos de crenças, inclusive aos não crentes, contudo, não se preocupa em anunciar como política oficial do Estado que aqueles que não têm religião encontram-se profundamente equivocados.

Pelo contrário, um Estado secular deve ser tolerante com todas as religiões, inclusive com manifestações pacíficas de religiões fundamentalistas. Não deveria aceitar referências religiosas ou ateias em seus pronunciamentos oficiais, nem autorizar a montagem de árvores de Natal em propriedades públicas.

Apesar de ambos os modelos pregarem a tolerância com quaisquer religiões

\footnotetext{
${ }^{164}$ DWORKIN, Ronald. Is democracy possible here? Principles for a new political debate. Princeton: Princeton University Press, 2006, p. 52-78.
} 
pacíficas, a concepção de cada um acerca da liberdade religiosa muda bastante. A sociedade que apoia um Estado religioso tolerante acredita na liberdade de crença em razão da especial importância que a religião tem na vida das pessoas. Tal direito estaria baseado na possibilidade de crença em um ser sobrenatural, que impediria as pessoas de decidir sobre questões éticas fundamentais, tais como, aborto, eutanásia, células-tronco.

Já uma sociedade secular não aceita uma visão estreita da liberdade religiosa. Uma sociedade religiosa encontra uma justificativa especial para a existência do direito à liberdade religiosa. O central num Estado secular é valorizar a liberdade de escolha entre quaisquer convicções, religiosas ou não. Não se admite a tomada de decisão governamental com base em princípios religiosos.

Para o autor, a questão está em definir em que modelo se enquadrariam os EUA. O país teria sido fundado como uma sociedade religiosa tolerante. Após a Segunda Guerra Mundial, juízes transformaram os EUA numa sociedade secular contra a vontade da maioria dos americanos. O movimento que hoje se verifica na política norte-americana é de conduzir a religião ao seu papel original.

Dworkin cita a declaração do Justice Anthony Kennedy ao afirmar que um Estado tolerante não deve agir de modo a rejeitar qualquer tipo de manifestação religiosa que eventualmente faça não religiosos se sentirem desconfortáveis. A democracia americana estaria mais próxima de uma sociedade religiosa tolerante, afinal há invocação da crença na Nação em deus em diversos momentos, desde a impressão na moeda até a realização de orações em aberturas de sessões legislativas.

Historicamente, os EUA seriam, portanto, um Estado religioso. Caberia discutir, então, a possibilidade de substituir os princípios religiosos que têm baseado a sociedade americana por questões de razão pública. Tal solução encontra, contudo, uma dificuldade para aqueles cidadãos que confundem suas convicções políticas com as religiosas.

A alternativa para o autor não seria excluir do debate político as convicções religiosas, mas sim contrapô-las com as convicções liberais que propugnam a separação entre política e religião. Para tratar do problema religioso, o autor baseia-se numa concepção de liberdade, segundo a qual fica proibido qualquer tipo de coerção baseada em julgamentos pessoais. Esta definição acaba se adequando mais a uma sociedade secular do que uma religiosa. 


\section{II.2.4- Modelos concordatários europeus}

A liberdade religiosa, na Europa, foi retardada em razão da tradicional existência de teorias que pregavam a unidade teológico-política. Tentou-se, com o advento do constitucionalismo liberal, reverter os velhos institutos religiosos para uma nova perspectiva constitucional.

Permanece sendo frequentemente lembrado o caráter público da religião. A liberdade religiosa ainda costuma ser garantida nos mesmo termos da liberdade eclesiástica. A solução em muitos países foi subordinar as concepções religiosas aos princípios constitucionais. Pelo princípio da primazia da Constituição as confissões religiosas devem se subordinar em todas as suas relações aos princípios da dignidade e liberdade de todos os cidadãos.

Nos países de forte tradição religiosa, por um lado considera-se a Constituição o fundamento de toda a ordem jurídica e também do direito eclesiástico. Existe, por outro lado, uma tendência em manter o sistema concordatário, tentando-se mostrar uma compatibilidade com a Constituição.

O sistema concordatário em sua configuração tradicional envolve um importante número de prestações estatais e financeiras dirigidas às confissões religiosas dominantes, que não correspondem aos benefícios concedidos pelos poderes públicos às entidades seculares.

O modelo de sistema concordatário atualmente começa a sofrer as críticas do Estado Constitucional, que não admite que a afirmação de um caráter público da religião signifique a publicização de umas religiões e a privatização de outras.

Muitas são as críticas ao sistema concordatário. A primeira delas é que a realização de um acordo entre as religiões e o Estado enxerga a sociedade somente como instituições e não como cidadãos titulares de direitos. Ademais, este tipo de regulamentação bilateral pode gerar uma conformação das questões religiosas ao panorama político, fazendo com que o exercício das liberdades religiosas dependa de uma celebração de acordo com o Estado. ${ }^{165}$

\section{II.2.5- Conceito de laicidade da CF/88}

O art. 19, em seu inciso I, prevê ser vedado à União, aos Estados, ao Distrito Federal e aos Municípios "estabelecer cultos religiosos ou igrejas, subvencioná-los,

\footnotetext{
${ }^{165}$ MACHADO, Liberdade religiosa..., 1996, p. 320-330.
} 
embaraçar-lhes o funcionamento ou manter com eles ou seus representantes relações de dependência ou aliança. ressalvada na forma da lei, a colaboração de interesse público."

Pela proibição de estabelecer cultos religiosos, a interpretação deve ser num sentido amplo, de modo a se entender que o Estado não pode criar religiões ou seitas, nem fazer propaganda de caráter religioso. A vedação de subvencionar refere-se à impossibilidade de o Estado concorrer com dinheiro ou quaisquer outros bens para o exercício da atividade religiosa. Não pode o Estado embaraçar o exercício das religiões, no sentido de que não podem ser criadas dificuldades para limitar ou restringir a prática, psíquica ou material, de atos ou manifestações religiosos. Por fim, há a ressalva feita na colaboração de interesse público. Entende a doutrina que tal colaboração deverá ser geral, para que não haja qualquer tipo de discriminação entre as religiões. Um exemplo dessa colaboração é a destinação de recursos públicos a escolas confessionais. ${ }^{166}$

As disposições do art. 19 correspondem às chamadas vedações de natureza federativa, sendo que o inciso I impõe proibições aos entes federativos no seu relacionamento com as Igrejas, que são responsáveis pelo estabelecimento do Estado laico.

A grande exceção às proibições do art. 19, I refere-se à dita colaboração de interesse público. Tendo a relação entre o Estado e a Igreja caráter de colaboração de interesse público, a aliança será permitida principalmente se envolver o setor educacional, assistencial e hospitalar. Essa aliança, contudo, deverá ter um caráter social e não religioso. $^{167}$

Será na linha da prevalência do interesse público que serão permitidas as diversas amenizações ao princípio da rígida separação entre Estado e Igreja, que serão analisadas no decorrer deste trabalho.

Entende Manoel Gonçalves Ferreira Filho ${ }^{168}$ que está presente no Brasil o sistema da separação entre Estado e Igreja, mas tal separação configura-se numa neutralidade atenuada, simpática à religião e às igrejas. Chega o autor a tal conclusão por diversas disposições da Constituição de 1988: a) a Constituição não é atéia, pois invoca no preâmbulo o nome de Deus, como vem ocorrendo desde a Constituição de $1934^{169}$; b) a

\footnotetext{
${ }^{166}$ SILVA, 2010, p. 251-2.

${ }^{167}$ CRETELLA JR., 1997. Vol. III, p. 1179-80.

${ }^{168}$ FERREIRA FILHO, Religião, Estado...,2002, p. 81-89.

169 Acerca do tema é bastante interessante citar a ADIN 2076-5/AC (STF - Pleno - Rel. Min. Carlos Velloso - D.J. 08.08.2003) que discutiu a possibilidade de a Constituição do Acre não invocar Deus em seu preâmbulo. $\mathrm{O}$ fundamento central para a improcedência da ação de inconstitucionalidade foi o entendimento de que a invocação de Deus no preâmbulo da Constituição Federal não é norma de reprodução obrigatória. No entanto, algumas considerações foram feitas com relação à laicidade do Estado. Acerca da invocação de
} 
consagração como absoluta da liberdade de crença (art. $\left.5^{\circ}, \mathrm{VI}\right)$; c) separação entre Estado e Igreja (art. 19, I); d) possibilidade de colaboração de interesse público; e) permissão da escusa de consciência (art. $\left.5^{\circ}, \mathrm{VIII}\right) ; \mathrm{f}$ ) garantia da liberdade de culto (art. $\left.5^{\circ}, \mathrm{VI}\right)$; g) proteção na forma da lei aos locais de culto e às suas liturgias; h) favorecimento das Igrejas ao conceder-lhes imunidade tributária.

Tanto é verdade que a laicidade no Brasil não é rígida que o preâmbulo da Constituição de 1988 invoca a proteção do Deus. No dizer de Alexandre de Moraes, "o fato de ser uma Federação-leiga não nos confunde com os Estados-ateus, pois o Brasil, expressamente, afirma acreditar em Deus [...]."170

Deus na Constituição Federal entende o Min. Carlos Velloso que "reflete, simplesmente, um sentimento deísta e religioso, que não se encontra inscrito na Constituição, mesmo porque o Estado brasileiro é laico, consagrando a Constituição a liberdade de consciência e de crença (C.F., art. $\left.5^{\circ}\right)$, certo de que ninguém será privado de direitos por motivos de crença religiosa ou de convicção filosófica ou política (C.F., art. $5^{\circ}$, VIII). A Constituição é de todos, não distinguindo entre deístas, agnósticos ou ateístas."

${ }^{170}$ MORAES, Alexandre de. Direito constitucional. 25 ed. São Paulo: Atlas, 2010, p. 299. 


\section{III - REFLEXOS DA LAICIDADE DO ESTADO NO ORDENAMENTO JURÍDICO}

\section{III.1- Introdução}

Analisadas as bases fundamentais da liberdade de crença e de culto, passarse-á agora a tratar dos desdobramentos oriundos do reconhecimento de tais liberdades por um ordenamento jurídico.

A liberdade religiosa que deve ser garantida pelo Estado por expressa ordem constitucional traz à tona um problema recorrente em harmonizar tal garantia com o caráter laico do Estado. A própria Constituição garante direitos decorrentes da liberdade religiosa que geram problemas de harmonização, como é o caso da escusa de consciência, da assistência religiosa e do ensino religioso.

Nem todas as consequências, contudo, da garantia da liberdade religiosa se encontram em normas constitucionais. Muitas delas surgem como problemas fáticos, cuja solução depende de diversos fatores que vão além da mera consagração teórica da liberdade religiosa. Como exemplo, pode ser citada a questão da transfusão de sangue em Testemunhas de Jeová, a discussão sobre o aborto entre outras, sobre símbolos religiosos em prédios públicos, entre outros.

\section{III.2- Escusa de consciência}

A Constituição Federal em seu art. 5, VIII dispõe que:

VIII- ninguém será privado de direitos por motivo de crença religiosa ou de convicção filosófica ou política, salvo se as invocar para eximir-se de obrigação legal a todos imposta e recusar-se a cumprir prestação alternativa fixada em lei

Por tal dispositivo, da mesma forma que a Constituição garante a liberdade de pensamento tanto filosófico quanto religioso, ela não admite que tal liberdade seja utilizada indiscriminadamente para o não cumprimento de obrigações legais impostas a todos. A alegação de motivos religiosos, apesar de permitida pelo texto constitucional, terá como consequência a necessidade de cumprimento de prestação alternativa prevista em lei. ${ }^{171}$

${ }^{171}$ CRETELLA JR., 1997. Vol. I., p. 253. 
Tal previsão constitucional, conhecida como escusa de consciência, guarda sentido na exata medida em que a liberdade de consciência pode ser considerada o núcleo básico de todas as liberdades do pensamento. Assim, somente poderá ser sancionado em razão de crenças religiosas com a perda dos direitos políticos o indivíduo que deixar de cumprir obrigação a todos imposta e ainda descumprir a prestação alternativa prevista em lei. $^{172}$

A Constituição não confere proteção apenas à liberdade de crença, mas também à liberdade de agir de acordo com essa crença, sem que isso lhe acarrete algum prejuízo. Agir de acordo com uma crença não significa necessariamente proselitismo. Eis o sentido da consagração da escusa de consciência. ${ }^{173}$

Se por um lado a previsão da objeção de consciência pode ser vista como a consagração da impossibilidade de alegação injustificada de motivo religioso, por outro pode ser vista como a permissão de que cidadãos se eximam de seus deveres jurídicos por motivos filosóficos ou religiosos.

Celso Ribeiro Bastos entende, diversamente do restante da doutrina, que "há uma possibilidade de invocação ampla da escusa de consciência, mas desde que seja feita para evadir-se o interessado de uma obrigação imposta a alguns ou a muitos, mas não a todos"174.

A escolha da prestação alternativa deverá ser feita pelo Poder Público e não pelo cidadão que alegou objeção de consciência. A despeito de a escolha caber ao Estado, a prestação alternativa a que se submeterá o cidadão deverá estar previamente prevista em lei. $^{175}$

A previsão da prestação alternativa é inovação desta Constituição, não existindo no texto anterior. A Carta precedente previa como consequência da objeção de consciência a perda dos direitos incompatíveis com a escusa de consciência. Assim, a lei deveria indicar não apenas a prestação alternativa, mas também quais direitos seriam perdidos. $^{176}$

A não privação de direitos políticos imposta pela Constituição Federal não é absoluta, já que o argumento de basear-se em motivos religiosos nem sempre terá o condão

\footnotetext{
${ }^{172}$ MORAES, 2011, p. 126

${ }^{173}$ FERREIRA FILHO, Curso de direito constitucional, 2002, p. 290.

${ }^{174}$ BASTOS, 2001, p. 493-507.

175 CRETELLA JR., 1997. Vol. I., p. 253.

${ }^{176}$ FERREIRA FILHO, 1990, p. 34.
} 
de impedir qualquer tipo de punição à pessoa. ${ }^{177}$ É o que prevê o instituto da escusa de consciência, já que a alegação de crença religiosa ou filosófica impede a prestação de serviços a todos imposta, mas exige o cumprimento de prestação alternativa.

Veja-se o art. $143, \S 1^{\circ}$ da $\mathrm{CF} / 88$, segundo o qual:

Às Forças Armadas compete, na forma da lei, atribuir serviço alternativo aos que, em tempo de paz, após alistados, alegarem imperativo de consciência, entendendo-se como tal o decorrente de crença religiosa e de convicção filosófica ou política, para se eximirem de atividades de caráter essencialmente militar.

Tal dispositivo exemplifica um caso de escusa de consciência em relação ao serviço militar. A referida norma constitucional é considerada não autoaplicável, necessitando a complementação através de lei infraconstitucional. A regulamentação foi feita através da Lei 8.239/91, que previu a prestação alternativa para quem se recusar a prestar serviço militar.

O mesmo art. 143 , em seu $\S 2^{\circ}$, exclui as mulheres e os eclesiásticos do serviço militar, entendendo-se eclesiásticos como membros de uma Igreja.

Por fim, é importante recordar o disposto no art. 15, IV da CF/88 para quem descumpre ou cumpre de maneira incompleta a prestação alternativa. Estabelece o texto constitucional que o inadimplente também da prestação alternativa, na escusa de consciência, tenha seus direitos políticos cassados. ${ }^{178}$

Assim entende Canotilho, ${ }^{179}$ ao afirmar que a liberdade religiosa garante a impossibilidade de discriminação por motivos religiosos, mas também não autoriza que os cidadãos se eximam de seus deveres jurídicos. A única exceção seria a previsão da objeção de consciência. Afinal, ainda que ela não exima o cidadão de cumprir uma prestação alternativa, ela permite que a obrigação original não seja cumprida.

Tratando de prestação alternativa, é interessante citar julgado do Tribunal Constitucional Português em que se questionou a validade da imposição de prestação alternativa de mesma gravidade que o serviço militar. Afirmou o Tribunal Constitucional que:

\footnotetext{
${ }^{177}$ FERREIRA, W., 1997, p. 161.

178 SORIANO, A., p. 99-100.

${ }^{179}$ CANOTILHO; MOREIRA, 1993, p. 243.
} 
No preceito em causa prevê-se um ónus cujo preenchimento condiciona o exercício do direito. Este não sofre, em si, qualquer compressão, ficando totalmente incólume, mesmo que o ónus não seja cumprido. $\mathrm{O}$ objector pode sempre exercer o direito quando quiser, e exercê-lo em pleno, isto é, sem perda de qualquer das faculdades que lhe são inerentes. Mas se quiser exercê-lo tem de preencher as condições que a lei estabelece, por motivos vários, inclusive organizativos. ${ }^{180}$

Ainda que a Constituição permita o não cumprimento de obrigações por motivos religiosos ou filosóficos, não há que se questionar a validade da exigência de prestação alternativa. A escusa de consciência seria, portanto, um direito condicionado, já que somente poderia ser exercido plenamente, sem sanções, caso haja o cumprimento de prestação alternativa.

A Constituição Portuguesa, assim como a Pátria, não apenas consagra o direito à objeção de consciência ligada à prestação de serviço alternativo, mas também faz referência à existência de uma lei regulamentadora. Diferentemente do que ocorre no Brasil, a lei regulamentando a escusa de consciência existe em Portugal e exige junto com a declaração de recusa à obrigação, uma declaração de disponibilidade à prestação de serviço cívico.

O Tribunal Constitucional de Portugal entende que a exigência da declaração de disponibilidade para o serviço cívico é responsável por garantir a seriedade da declaração de objeção de consciência, resguardando assim o interesse da sociedade no cumprimento de obrigações a todos imposta. ${ }^{181}$

Tal tipo de exigência parece ser salutar na consagração da escusa de consciência. Afinal, devem ser adotadas todas as cautelas para evitar que tal instituto seja utilizado por pessoas oportunistas que aleguem uma falsa crença religiosa apenas para eximir-se de uma obrigação. Ainda que os objetores de fato acreditem na crença alegada, não há justificativa para que se neguem ao cumprimento de uma prestação alternativa. A recusa inicial deve ser feita com seriedade, havendo predisposição do objetor em servir o Estado por meios que não ofendam a sua crença.

\footnotetext{
${ }^{180}$ PORTUGAL - Tribunal Constitucional Português - acórdão nº 681/95 - Processo no 390/95 - Plenário -

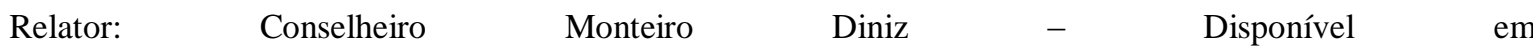
http://www.tribunalconstitucional.pt/tc/acordaos/19950681.html - Acessado em 08/01/2012.

${ }^{181}$ PORTUGAL. Tribunal Constitucional Português - $\operatorname{Proc}^{\circ} n^{\circ} 534 / 94$ - Acórdão no 5/96 - $2^{\text {a }}$ Seção Relator:- $\quad$ BRAVO SERRA. $\quad-\quad$ Disponível http://www.tribunalconstitucional.pt/tc//tc/acordaos/19960005.htm. No mesmo sentido: Acórdão no 95/96 Processo $n^{\mathrm{o}} 32 / 95$ - $1^{\mathrm{a}}$ Seção - Relator: Conselheiro Ribeiro Mendes - Disponível em http://www.tribunalconstitucional.pt/tc//tc/acordaos/19960095.html - Acesso em 08/01/2012
} 
Através da objeção de consciência, o cidadão não será obrigado a praticar atos que agridam a sua consciência individual, não só naquilo que diz respeito a motivos religiosos, mas também a questões filosóficas e morais. A objeção também não se restringe apenas ao serviço militar, já que abarca qualquer tipo de obrigação genericamente imposta. $^{182}$

Rámon Soriano ${ }^{183}$ faz uma interessante comparação entre a objeção de consciência e a desobediência civil. A objeção de consciência representa algo mais que uma liberdade de ideias, ideológica ou de pensamento. Trata-se de uma objeção de consciência ou em consciência, isto é, de uma atitude ante um problema, que admite diversas soluções entre as quais o objetor deve eleger responsavelmente, de modo a atuar de acordo com a sua consciência.

Seria, portanto, uma liberdade de crença, seguindo o indicativo constitucional, ou uma liberdade de consciência. Uma liberdade de crença ou de consciência que se caracteriza por exigir a exceção ao cumprimento de um dever jurídico imposto pelo ordenamento em virtude da prevalência de um dos motivos da consciência.

No que diz respeito à objeção de consciência, é interessante realizar uma diferenciação com o instituto da desobediência civil. Afinal, ambas representam uma forma de descumprimento das regras jurídicas impostas. Pode-se enxergar até uma relação de gênero e espécie, sendo a objeção de consciência a espécie. Tais institutos, contudo, são bastante diferentes.

A desobediência civil tem como pressuposto a ineficácia das ações legais, de modo que a melhor forma para se produzir uma mudança no governo é a mobilização da opinião pública. A desobediência apresentaria, assim, os seguintes requisitos: a) não afeta todo o ordenamento jurídico; b) a causa é um motivo de justiça, o que não acontece na desobediência criminal; c) caracteriza-se, formalmente, pela publicidade; d) não utiliza meios violentos e; e) pressupõe a ineficácia dos meios legais de mudança.

A justificativa da desobediência civil repousaria tanto na falta de harmonia entre a prática e os valores jurídicos quanto nos vícios do processo democrático, que poderiam ser: desrespeito às minorias; decisão política desrespeitadora dos direitos essenciais das minorias e; falta de participação dos cidadãos na tomada de decisões relevantes para o país.

\footnotetext{
${ }^{182}$ CANOTILHO; MOREIRA, 1993, p. 245.

${ }^{183}$ SORIANO, R., 1990, p. 15-34.
} 
A objeção de consciência, por sua vez, significa a possibilidade de desrespeito a um dever jurídico, nos casos em que seu cumprimento conflitaria com a consciência do indivíduo. Diferentemente da desobediência civil, a objeção de consciência não pretende contrariar instituições jurídicas. Ela é direcionada ao cumprimento de uma norma em relação tão-somente ao objetor. Não há, na verdade, um descumprimento do dever jurídico, mas sim a sua substituição por outro, que pode inclusive ser mais oneroso.

São requisitos ou condições da objeção de consciência: a) a escusa de consciência refere-se a apenas uma norma jurídica; b) a razão da objeção é a ética do objetor; c) formalmente, é um ato privado; d) caracteriza-se por meios não violentos; e) não se pretende a mudança das normas, mas apenas a sua exceção por um caso concreto; $f$ ) não deve causar danos essenciais e irreversíveis a terceiros.

Fala-se em danos essenciais quando a escusa de consciência fere direitos fundamentais de outra pessoa, e.g., a objeção de testemunhas de Jeová à transfusão de sangue que pode ferir o direito à vida de outrem. Tal fator de essencialidade acaba perdendo sentido caso a objeção refira-se a instituições e não a pessoas. Já no que diz respeito à irreversibilidade do dano, ela pode ser mitigada de duas formas. No que diz respeito à objeção dirigida a instituições, o dano pode ser diminuído à imposição de deveres alternativos. Já se a objeção referir-se a pessoas, a melhor maneira de mitigação seria a substituição do objetor por outrem que cumpra o dever excepcionado.

Costuma-se rejeitar a ideia de que a desobediência civil é a contrariedade ao princípio da justiça das normas democráticas, já que os desobedientes pretendem que normas jurídicas sejam alteradas ou anuladas. Já na objeção de consciência, o objetor não pretende extirpar a norma do ordenamento jurídico, nem que ela deixe de ser aplicada aos demais. Pretende-se apenas que a norma não seja aplicada para o objetor em razão de sua consciência.

Para que a objeção de consciência seja aceita num Estado Democrático de Direito, seria preciso considerar três fatores: titularidade, conteúdo e efeitos do dever jurídico afetado. Assim, a objeção de consciência não poderia ser alegada para afastar um direito pessoal e intransferível, nem quando houvesse impossibilidade de substituição por uma prestação alternativa ou quando causasse danos irreversíveis a direitos fundamentais de outras pessoas. 
Na Europa, a objeção de consciência tem assento constitucional em alguns países, tais como, Áustria, Holanda, Alemanha, Portugal e Espanha. Já em outros países, o seu reconhecimento dá-se através de lei.

Já nos EUA, a jurisprudência trata a objeção de consciência como uma ponderação entre os interesses gerais da coletividade e os particulares dos objetores. Temse permitido a objeção de consciência quando a sua negação representasse um dano à liberdade de pensamento e, pelo contrário, tem-se negado a objeção quando ela somente significaria a perda de um benefício derivado do comportamento do objetor.

O instituto da objeção de consciência teve como precedente no Tribunal Constitucional da Alemanha de 13 de abril de 1978 julgado que entendeu a objeção de consciência como um direito fundamental, mais especificamente como um tipo de liberdade ideológica. E como tal poderia ser aplicado através de um procedimento perante uma Comissão avaliadora da veracidade da decisão do objetor.

Ressalta Raymond Goy, ${ }^{184}$ que na Convenção de Roma a objeção de consciência é reconhecida, mas seu texto não obriga os Estados a reconhece-la em seu ordenamento, apenas permitindo que tal seja feito.

Autores ${ }^{185}$ relembram que, em diversos Estados europeus, foi criado o que se chama "imposto de paz", para englobar aqueles que se recusam a pagar qualquer tipo de imposto de guerra, referente a toda participação militar. Tal tipo de sistema poderia gerar um conflito bastante complicado, pois acabaria discriminando entre os que se recusam a pagar qualquer tipo de imposto e os que se recusam a pagar impostos de guerra.

O princípio da objeção de consciência ao serviço militar é geralmente reconhecido em toda a Europa. Mas a questão de recusa de atendimento ao serviço civil alternativo, essencialmente, por Testemunhas de Jeová, não encontra outras respostas jurídicas que as sanções penais acompanhadas às vezes de penas de prisão bastante altas, como se verifica na Bélgica, Espanha e Portugal.

Em diversos julgados da Corte Europeia de Direitos Humanos, a demanda concentra-se em casos em que os objetores alegam violação ao art. 9 da Convenção por terem sido condenados a penas em razão de recusa ao serviço militar. A Corte não enxerga nenhuma violação ao texto da Convenção exatamente pelo fato de os Estados signatários não serem obrigados a aceitar a objeção de consciência. Não reconhecendo o Estado o

\footnotetext{
${ }^{184}$ GOY, 1993, p. 199.

${ }^{185}$ GONZALEZ, 1997, p. 129-131.
} 
instituto da escusa de consciência, a pessoa que pretender exercê-la poderá ser punida, como o foi nos casos julgados ${ }^{186}$.

A Corte entendeu em caso oriundo da Turquia que sucessivas condenações penais pela recusa de um pacifista a ingressar no serviço militar seria abusiva, ainda que frente a uma ausência de regulamentação legal para a escusa do serviço militar por razões de convicções pessoais. ${ }^{187}$

A escusa de consciência é vista como uma prática que se expressa negativamente, através de uma recusa. Assim, são elementos identificadores de uma prática negativa: firme convicção; construção sólida acerca do fato alegado; demonstração de que o indivíduo não está isolado, mas que faz parte de uma Igreja com exigências de comportamento reconhecidas socialmente.

Na França ${ }^{188}$, o artigo 41 da Lei 71.424 de 1971 permite que os jovens antes da incorporação ao serviço militar declarem oposição ao uso de armas em razão de convicções filosóficas ou religiosas. Quem fizer tal objeção deverá cumprir a lei de recrutamento, seja numa formação militar não armada, seja numa formação civil. A demanda é submetida a uma comissão jurisdicional, composta por um magistrado, três oficiais e três personalidades indicadas pelo Primeiro Ministro. Contra a decisão, não cabe nenhum recurso, salvo um de cassação para o Conselho de Estado.

A Comissão jurisdicional deve tentar julgar a sinceridade da convicção filosófica ou religiosa alegada pelo objetor e evitar que haja um caráter político, refletindo um movimento antimilitarista. A Comissão, a partir de um determinado momento, começou a preocupar-se cada vez mais com o caráter individual das demandas. Quando o número de demandas cresceu significativamente e as petições quase se tornaram idênticas, a Comissão passou a rejeitar os pedidos com maior frequência.

O Conselho de Estado, funcionando como Corte de Cassação, começou a recusar a realização do pedido de modo genérico. Afinal, a sinceridade de uma convicção não poderia ser expressada por uma fórmula genérica, utilizada por mais de um objetor.

${ }^{186}$ CORTE EUROPEIA DE DIREITOS HUMANOS. Grandrath v. Alemanha (n. 2299/64), julgado em 12/12/66; X v. Áustria (n. 5591/72), julgado em 02/04/73 - Disponível em http://www.echr.coe.int/NR/rdonlyres/E0941C75-D511-487B-A991-

55A7074B5E59/0/FICHES Liberté religion_FR.pdf - Acesso em 11/05/2011.

${ }^{187}$ CORTE EUROPEIA DE DIREITOS HUMANOS. Ülke v. Turquia (n. 39437/98), julgado em 24/01/06 Disponível em - $\quad$ http://www.echr.coe.int/NR/rdonlyres/E0941C75-D511-487B-A99155A7074B5E59/0/FICHES_Liberté_religion_FR.pdf - Acesso em 11/05/2011

${ }^{188}$ COLLIARD, 1979, p. 419-21. 
Considerando que as ações da Comissão passaram a ser anuladas pelo Conselho do Estado, começou-se a exigir uma justificativa suplementar e por escrito acerca dos motivos da objeção de consciência. Tal procedimento, que eliminou a comparação entre os objetores, acabou sendo aceito pelo Conselho de Estado.

A exigência de sinceridade na manifestação religiosa também está presente nos EUA. É o que se percebe em United States v. Seeger, em que a Corte Suprema decidiu que a crença das pessoas deve ser sincera e significativa e que deve ocupar na vida delas o mesmo lugar que Deus. Assim, a natureza da convicção ou da crença não seria importante, pois o que de fato tem relevância seria a sinceridade e a importância que a alegação teria na vida da pessoa. ${ }^{189}$

$\mathrm{Na}$ Espanha, a definição do regime da objeção de consciência depende do legislador ordinário. A objeção ao serviço militar foi disciplinada pela Lei 22/1998 e seu reconhecimento depende de uma declaração dirigida ao Conselho Nacional de Objeção de Consciência, que deverá apreciar a petição sem discutir o mérito das convicções.

A apresentação da dita declaração gera a discussão acerca de possível violação ao direito de intimidade do objetor. Acabou sendo decidido que a ponderação acerca da conveniência e da profundidade da declaração caberia exclusivamente ao objetor.

Pelo regime espanhol, a prestação alternativa para a escusa ao serviço militar consiste no desenvolvimento de atividades de utilidade pública que não exijam emprego de armas nem tenham relação com a instituição militar, em setores como o serviço social, ajuda a refugiados, cooperação internacional, conservação do meio ambiente, alfabetização etc.

O ordenamento espanhol não admite uma nova escusa de consciência com relação à prestação alternativa. Para tais casos, o Código Penal prevê pena de inabilitação para exercício de cargos públicos pelo tempo de 4 a 6 anos. ${ }^{190}$

Tratando-se, ainda, de escusa de consciência, bastante interessante é um julgado do Tribunal de Justiça de Goiás ${ }^{191}$. Em tal acórdão, um adventista alega, sob o pretexto de escusa de consciência, a vontade de que um estabelecimento localizado num condomínio não abra aos sábados. O Tribunal entendeu que não configuraria ofensa à

189 SILVA NETO, Manoel Jorge. A Suprema Corte norte-americana e a liberdade religiosa. Revista Brasileira de Direito Público, Belo Horizonte, v. 5, n. 19, out./dez., 2007, p. 110.

${ }^{190}$ LÓPEZ CASTILLO, 2001, p. 14-17.

191 TJ-GO - AgI 40200-8/180 - 1ª Câmara Cível - Rel. Des. João Ubaldo Ferreira - DJ 14/02/2005. 
liberdade de crença a obediência ao regulamento do condomínio quanto ao horário de abertura de estabelecimentos comerciais aos sábados.

\section{III.3- Assistência religiosa}

De acordo com o art. 5, VII da CF/88, "é assegurada, nos termos da lei, a prestação de assistência religiosa nas entidades civis e militares de internação coletiva."

$\mathrm{O}$ direito à assistência religiosa já existia na Constituição anterior e sua previsão era mais ampla que a atual. A Constituição de 1967 falava em assistência aos internados em estabelecimentos civis e militares e às Forças Armadas e auxiliares. O texto atual faz referência apenas a estabelecimentos de internação coletiva e não às Forças Armadas. Há que se notar, também, que não há mais a obrigatoriedade em que a assistência religiosa seja prestada apenas por brasileiros. ${ }^{192}$

De acordo com Alexandre de Moraes ${ }^{193}$, tal artigo da Constituição confere um direito subjetivo ao indivíduo que se encontra internado em estabelecimento coletivo. Caberia ao Estado conferir as condições materiais necessárias para que essa assistência religiosa seja prestada conforme as crenças solicitadas pelos internos.

Certamente, não poderá haver uma obrigação a que os internos recebam a assistência religiosa. Ela se configura numa faculdade e, nesse sentido, não tem razão para ser entendida como um desrespeito à laicidade do Estado. Afinal, apesar de ser laico, o Estado brasileiro não é ateu. Muito menos seria uma violação à liberdade religiosa dos internos, pois quem não professar nenhuma crença não será obrigado a receber assistência religiosa.

A neutralidade do Estado não impõe que seja negada aos cidadãos a possibilidade de receber assistência religiosa em estabelecimentos de internação coletiva. Igualmente, cabe dizer que apesar de a Constituição não falar em assistência religiosa para as Forças Armadas também não a proíbe. ${ }^{194}$

Celso Ribeiro Bastos e Ives Gandra ${ }^{195}$ entendem que nesse artigo reside uma garantia positiva do Estado com relação à liberdade religiosa, mas que deve ser exercida de acordo com determinados parâmetros. Primeiro, a igreja do interno deve dispor-se a oferecer a assistência requerida, já que o dever do Estado restringe-se a oferecer os meios

\footnotetext{
${ }^{192}$ FERREIRA FILHO, 2000, Vol. I, p. 33.

${ }^{193}$ MORAES, 2011, p. 134.

194 FERREIRA FILHO, 2000, Vol. I, p. 34.

195 BASTOS, Celso Ribeiro; GANDRA, Ives. Comentários à Constituição do Brasil. São Paulo: Saraiva, 1989, v. 2.
} 
para que ela ocorra, não devendo, portanto, ser responsabilizado pela prestação, dado o caráter laico do Estado brasileiro.

A Constituição anterior dispunha que tal assistência deveria ser voluntária e a despeito de a atual não fazer tal referência, ela deve continuar a ter tal caráter. Saliente-se ainda que a edição de uma lei infraconstitucional seria imprescindível para determinar em que termos será prestada tal assistência religiosa.

A doutrina costuma entender que tal assistência é um direito de presos, militares e hospitalizados. José Afonso da Silva ${ }^{196}$, contudo, entende que a assistência religiosa não se aplica às Forças Armadas, mas tão somente a penitenciárias, casas de detenção, casas de internação de menores etc.

A assistência religiosa nas Forças Armadas encontra-se regulamentada pela Lei 6.923/81, que prevê em seu art. $2^{\circ}$ ter como finalidade: "prestar assistência Religiosa e espiritual aos militares, aos civis das organizações militares e às suas famílias, bem como atender a encargos relacionados com as atividades de educação moral realizadas nas Forças Armadas."

Segundo a lei (art. $3^{\circ}$ ), o serviço de assistência religiosa deverá funcionar tanto em tempo de paz quanto em tempo de guerra.

Também a assistência religiosa encontra previsão no ECA, em seu art. 124, XIV, ao estabelecer o direito do adolescente em privação de liberdade receber assistência religiosa.

No que tange ao preso, é de se entender que a assistência religiosa deve ser oferecida de forma facultativa e não obrigatória. A Lei de Execuções Penais, em seu art. $3^{\circ}$ e o Código Penal, em seu art. 38, garantem, inclusive, a assistência religiosa a presos provisórios.

A previsão da assistência religiosa leva em consideração que os presos conservam seus direitos inerentes à pessoa humana, tais como a liberdade religiosa. Nesse sentido, é que se entende não ser possível impor pena de prestação de serviços à comunidade em templo religioso, que eventualmente agrida convicção religiosa do condenado. $^{197}$

\footnotetext{
${ }^{196}$ SILVA, 2010, p. 252.

197 SORIANO, A., 2002 p. 95-6.
} 
Corrobora tal entendimento o acórdão do TJ-SP, ${ }^{198}$ pelo qual se ressalta o direito à assistência religiosa do preso ou interno, que terá liberdade de culto. Dessa maneira, ninguém poderá interferir na convicção íntima do preso, cabendo ao Estado garantir todas as condições materiais para exercício do culto. A garantia de assistência religiosa não significa que o preso terá autorização para frequentar cultos fora dos domínios do presídio, uma vez que a assistência deverá ser prestada dentro dos estabelecimentos de internação coletiva.

A garantia da assistência religiosa não parece trazer muitos questionamentos. Ela deve ser fornecida aos internados em estabelecimentos coletivos que a requisitem. Cabe ao Estado apenas permitir que a assistência seja prestada e jamais prestar ele próprio qualquer tipo de assistência religiosa. Isso porque deve o Estado garantir a sua imparcialidade frente às religiões.

\section{III.4- Símbolos religiosos}

A problemática dos símbolos religiosos foi bem apontada por Robert, ${ }^{199}$ ao questionar se a liberdade de consciência no Estado laico deve reconhecer a cada um o direito de estar acompanhado ou de afixar ostensivamente os sinais exteriores de sua preferência a uma religião.

A discussão sobre a possibilidade de utilização de símbolos religiosos em um Estado Laico aparece sob duas perspectivas, quais sejam, o porte de símbolos religiosos por indivíduos dentro de prédios públicos e a afixação de símbolos religiosos nos próprios prédios. As duas questões apresentam características bastante diversas. O porte de símbolos religiosos por indivíduos, principalmente em escolas, recai no âmbito de proteção da liberdade de consciência e de seus limites frente à laicidade estatal. Por sua vez, a existência de símbolos nos prédios envolve o posicionamento do Estado de neutralidade e o seu respeito frente ao pluralismo religioso.

Em ambas as situações terão que ser confrontados diversos conceitos atinentes à garantia da liberdade religiosa, analisando-se na prática como deve-se portar o Estado ante a dupla obrigação de garantir a sua neutralidade e a liberdade dos indivíduos.

\footnotetext{
${ }^{198}$ TJ-SP - Agravo em Execução Penal 993010834963 - 4 Câmara de Direito Criminal - Rel. Des. Sinésio de Souza - Julgado em 16/04/2004

${ }^{199}$ ROBERT, 1993, p. 520-523.
} 


\section{III.4.1. Porte de símbolos religiosos e o véu islâmico}

O debate acerca do porte de símbolos religiosos por indivíduos ganhou bastante notoriedade na França com a crescente presença de imigrantes de religião islâmica e a concepção tradicionalmente rígida da separação entre Estado e Igreja.

A discussão na França ganhou corpo com a lei aprovada em 2004 que proibiu o porte de símbolos religiosos ostensivos em escolas públicas, atingindo principalmente o véu islâmico. O problema, contudo, já existia antes de 2004.

O Conselho de Estado em 1989 entendeu que a laicidade do ensino público impediria toda discriminação no acesso ao ensino que seja fundada sobre convicções ou crenças religiosas dos alunos. O Conselho entendeu que o porte pelos alunos de símbolos não é incompatível com o princípio da laicidade. Mas esses símbolos não serão permitidos quando portados de forma a constituir uma pressão, provocação ou proselitismo. ${ }^{200}$

Ademais, a conjugação do princípio da laicidade do ensino público e da neutralidade do serviço público imporia que os alunos no exercício de sua liberdade religiosa sejam dispensados de respeitar tal neutralidade. Para os alunos, a liberdade comporta o direito de exprimir no interior dos estabelecimentos, suas crenças religiosas em respeito ao pluralismo e à liberdade dos outros e sem desrespeitar as atividades de ensino, o conteúdo dos programas e a obrigação de assiduidade.

Seu exercício pode ser limitado na medida em que ele constitua um obstáculo ao cumprimento da missão desempenhada pelo serviço público. Assim, o porte pelos alunos de símbolos que demonstrem sua preferência por uma religião não significa por si só uma violação do princípio da laicidade. ${ }^{201}$

Novamente, voltando a se pronunciar acerca da possibilidade de porte de símbolos religiosos, o Conselho, em 1992, entendeu inconstitucional regra de uma escola que proibia todos os tipos de símbolos religiosos.

Com base, nessas já antigas decisões do Conselho de Estado francês, Robert salienta o surgimento de uma concepção positiva ou militante da laicidade do Estado, de maneira a levar em consideração o ambiente religioso existente na França, respeitando assim o pluralismo que permita levar, inclusive, o ensino da história da religião à escola pública.

\footnotetext{
${ }^{200}$ COLLIARD, 1979, p. 351.

${ }^{201}$ DRAGO, Roland. Laicité, neutralité, liberté? Archives de Philosophie du Droit, Paris, n. 38, 1993, p. 229.
} 
A laicidade francesa sempre foi vista como um modelo para outros países. O modelo francês, contudo, funcionava muito bem para a relação entre Estado e Igreja Católica. Com o surgimento de novos movimentos religiosos no país como o islamismo, tal modelo de laicidade começou a ser discutido.

Dominique le Tourneau ${ }^{202}$ cita diversas decisões de Tribunais Administrativos franceses, que frequentemente se mostraram contrários à utilização de símbolos religiosos, mesmo antes da lei de 2004.

Tribunal Administrativo de Clermont-Ferrand decidiu em 1995 que o véu islâmico é por si só ostensivo e se apresentaria como um símbolo com significado extremista estrangeiro. Há quem entenda que o uso do véu está revestido de um caráter profundamente intolerante, negando às mulheres a igualdade reconhecida pelas instituições democráticas francesas.

O Tribunal Administrativo de Lyon em 1994 manteve a expulsão de duas irmãs muçulmanas de um colégio, ao motivo de que elas se recusavam a adotar uma roupa adequada às aulas de educação física.

Seguindo a sua jurisprudência anterior, o Conselho de Estado, diferentemente das decisões de Tribunais Administrativos, anulou decisão de expulsão de uma jovem muçulmana de uma escola com base em regra do regulamento de que nenhum aluno poderia assistir às aulas com a cabeça coberta.

Para o autor, em primeiro lugar, deve-se discutir o caráter ostensivo do véu islâmico. Para o Conselho de Estado, qualquer símbolo religioso e não só o véu islâmico pode ser ostensivo. Assim, o uso de símbolos religiosos pertence à liberdade religiosa dos cidadãos e não cabe aos chefes de estabelecimentos indagar a que religião pertence o aluno. Qualquer disposição que determine uma proibição genérica de uso de símbolos religiosos por alunos dentro de estabelecimentos públicos são ilegais, por serem cegas.

Há quem entenda que a obrigação de que a mulher ande com a cabeça coberta seria contrária à dignidade da mulher. No caso Ylmaz levado ao Conselho de Estado [expulsão de aluna], o Comissário do Governo entendeu que não cabe nem à Administração nem ao Judiciário analisar a tradição islâmica para determinar se há qualquer tipo de agressão à dignidade da mulher com o uso do véu.

${ }^{202}$ LE TOURNEAU, Dominique. El velo islâmico y la neutralidad de la escuela pública em Francia in Boletin Mexicano de Derecho Comparado. Universidad Nacional Autônoma de México, ano XXX, n. 89, mayo-agosto de 1997, p. 623-632. 
A religião católica aparentemente convive bem com o princípio da laicidade, já o mesmo não ocorre com o islã. No momento da separação entre Estado e Igreja, o islã não fazia parte da cultura francesa.

Em 2004, a Assembleia Nacional da França aprovou uma lei que proibia o uso de véus e símbolos religiosos ostensivos por alunos em escolas públicas. A partir desse momento, cresce exponencialmente a discussão acerca do tema.

Robert $^{203}$, analisando a proibição legal, começa por salientar que o texto da lei apesar de fazer referência a quaisquer símbolos religiosos acaba gerando prejuízos diretos aos muçulmanos e aos judeus e não aos cristãos. Segundo o autor, o principal efeito da lei será expulsar das escolas públicas todas as pessoas que se sintam oprimidas pela lei e não libertar, como muitos alegaram, as mulheres que se sentem oprimidas pelo uso do véu islâmico.

A questão se coloca exatamente naquilo que se deve entender por laicidade estatal. De acordo com o autor, a laicidade foi definida pela Lei de 1905 e pode ser exprimida por dois elementos básicos: a) o Estado não reconhece, nem subvenciona, nem assalaria qualquer culto; b) o Estado assegura a liberdade de consciência e a livre prática do culto.

O espaço público e o espaço privado são distintos. Não são hostis, inimigos ou indiferentes. Eles se conversam, se escutam, trocam informações, mas são de mundos distintos. Deve haver uma coexistência harmônica entre eles. Ninguém deverá ser impedido pelo Estado de crer naquilo que entende ser verdadeiro. $O$ único limite para essa tolerância é a ordem pública.

O Estado é neutro e tem como dever proteger a liberdade de culto dos cidadãos. Portar um símbolo religioso é uma expressão desta liberdade. A não ser que o símbolo por si só seja a exteriorização de uma religião cujo exercício pode ser a fonte de problemas. Mas tal fator deve ser necessariamente provado.

É possível ter outra visão da laicidade, em que a religião seria expulsa do espaço público, principalmente da escola. Por esta visão, seria contraditório defender que a escola deveria somente ensinar os fundamentos da República, considerando que tais fundamentos têm como princípio básico a não imposição de crenças e pensamentos aos demais.

${ }^{203}$ ROBERT, Jacques. Cacophonie. Revue Du Droit Public de La Science Politique en France et à l’Étranger. Paris, LGDJ, n. 2, 2004, p. 309-315 
O autor entende que a escola é o lugar mais adequado para que as pessoas troquem informações e ensinem aos outros o significado de suas religiões e dos símbolos que portam. Não se trata de permitir um proselitismo em que se pretende trocar as leis do país por regras e costumes de países estrangeiros.

A grande razão de inconstitucionalidade da lei estaria exatamente na ruptura do princípio da igualdade, já que o texto legal trata de maneira diferente pessoas que estão rigorosamente na mesma situação. A proibição de porte de um símbolo religioso seria plenamente admissível caso ele cause, na análise concreta, uma grave perturbação da ordem pública. E se o símbolo não tiver qualquer efeito nocivo para a sociedade? Mesmo assim ele deve ser proibido a priori?

Outro argumento para a inconstitucionalidade, trazido por Robert, é a falta de proporcionalidade da sanção em relação à falta cometida. Antes de falta de proporcionalidade, a questão está em não se vislumbrar nenhuma falta cometida pelo indivíduo.

A liberdade de consciência envolve a liberdade de crença e a liberdade de exercício do culto. A liberdade de crença envolve a possibilidade de professar a crença, difundi-la e fazê-la conhecida. É possível questionar, inclusive, se a proibição do uso de símbolos imposta pela lei retiraria o caráter laico do Estado, uma vez que há disposição legislativa destinada a algumas religiões específicas. A Declaração de 1789 já dizia que ninguém pode ser inquietado por suas opiniões, mesmo religiosas, se sua manifestação não agredir a ordem pública estabelecida pela lei.

A discussão sobre o uso do véu islâmico não surgiu apenas dentre autores franceses, mas se tornou presente em toda a Europa.

De acordo com Jean-François Flauss, ${ }^{204}$ a Corte Europeia de Direitos Humanos já havia enfrentado a questão dos símbolos religiosos muito antes da lei francesa de 2004. Os limites da liberdade de expressão religiosa dos agentes públicos estão bem longe de estar determinados com precisão. A solução consagrada pela Corte no caso Dahlab v. Suiça pode ser considerada como autorizando todos os funcionários, exceto os de ensino, a portar símbolos religiosos, inclusive o véu islâmico. A Corte somente não teria permitido o uso do véu por profissionais do ensino, em razão da idade dos alunos que poderiam atribuir ao véu um caráter proselitista. Esta decisão foi tomada por uma Câmara da Corte, que não necessariamente reflete a posição da Grande Câmara.

${ }^{204}$ FLAUSS, Jean-François. Laïcité et Convention européenne des droits de l'homme. Revue Du Droit Public de La Science Politique en France et à l'Étranger. Paris, LGDJ, n. 2, 2004, p. 320-323. 
Em 1993, a Comissão Europeia recusou conceder um caráter de prática religiosa ao véu islâmico nos termos do art. $9^{\circ}$ da Convenção e neste sentido considerou que a sua proibição não significaria uma intervenção inadequada do Estado na liberdade religiosa.

O vice-presidente da Corte em comentário à Comissão Stasi [responsável pela análise da lei francesa de 2004], entende que não há necessidade de edição de uma lei para que haja atos restritivos relacionados aos direitos protegidos pelo art. $9^{\circ}$ da Convenção. Contudo, a edição de uma lei seria muito recomendável considerando o direito interno.

Elisa Olivito $^{205}$ defende o posicionamento que professor de uma escola pública deve ser discreto em sua vestimenta no que diz respeito à sua própria crença, uma vez que ele representa o Estado. Tal proibição corresponde a um interesse público dominante que se constitui um limite da liberdade religiosa individual. A autora cita decisão do Tribunal Constitucional Alemão pela qual o uso do véu islâmico seria uma manifestação lícita da liberdade religiosa dos professores no ensino público, contrariando assim a ideia de neutralidade de funcionários do Estado.

Uma interpretação radical da laicidade levaria facilmente à criação de um ambiente de intolerância em que a diversidade perderia lugar para uma neutralidade irrestrita. É importante lembrar que a laicidade é imposição ao Estado e aos seus representantes, mas não aos indivíduos.

Ao tratar da batalha contra o véu islâmico, fortemente sentida na França e dissimulada como uma cruzada hipócrita contra todos os símbolos religiosos, a autora pretende revelar uma hostilidade no confronto do diferente, principalmente em relação à religião islâmica. A proibição ocorreu sob a alegação de que proteção à laicidade com o intuito de evitar que símbolos de apenas uma religião fossem ostentados em lugares públicos, tais como escolas públicas, o que ofenderia a neutralidade do espaço.

Ocorre que de acordo com o princípio da laicidade quem deve ser neutro é o Estado e não o indivíduo. Os espaços públicos devem criar condições favoráveis para que todos sejam livres para expressar a própria personalidade. O indivíduo não precisa ser neutro, mas pode abraçar toda a intensidade e senso de verdade absoluta da sua fé.

Existe uma diferença, no entender da autora, entre o Estado impor um símbolo religioso e reconhecer um símbolo como pertencente a uma religião. No primeiro

${ }^{205}$ OLIVITO, 2004, p. 570-7. 
caso, traz-se uma mensagem de equivalência quase de osmose entre os valores públicos e o ensinamento de uma confissão religiosa. Já no segundo, há apenas o reconhecimento de uma manifestação da liberdade religiosa que não afronta a laicidade, já que o ambiente permanece neutro.

A liberdade religiosa só poderia ser restringida quando sua manifestação em espaços públicos fosse exercida de forma a representar uma ameaça séria e incontestável aos demais direitos fundamentais.

É frequente argumentar que ao véu tenha sido dado um significado político, como se fosse um veículo do integralismo, em que a comunidade muçulmana, tentando impedir a ocidentalização da sua cultura, passa a usar o véu como um símbolo de resistência. A questão é como o Estado vai reagir a esta provocação, se com um fundamentalismo laico ou se com uma atitude de respeito à liberdade religiosa.

Pensa-se no véu como um símbolo de opressão da mulher, o que deveria ser combatido no ambiente escolar. Ocorre que esta proibição gera uma dupla opressão, primeiro da família e depois da escola.

Ademais, o uso do véu é uma decisão pessoal. O Estado laico não pode impor o estilo de vida das pessoas. Sua competência é, pelo contrário, oferecer a possibilidade de que todos se emancipem.

Naturalmente, a liberdade de ensino encontra um limite interno, que é a impossibilidade de tratar de assuntos que não dizem respeito ao ato de ensinar, como a propaganda política e o proselitismo religioso, e um limite externo que envolve a imaturidade intelectual e o temor reverencial dos alunos. $\mathrm{O}$ véu islâmico não infringe nenhum destes dois limites, primeiro, pois não é instrumento de proselitismo. Segundo, não terá nenhuma influência negativa nos alunos já que a visão de pessoas usando o véu gerará uma impressão de pluralismo religioso.

Estudando a questão na Espanha, Canamares Arribas $^{206}$ acredita que o conflito tem tido relação com o fenômeno da imigração e a consequente pretensão dos imigrantes de exercer no país de acolhida a sua liberdade religiosa de acordo com os seus costumes locais. O maior número de imigrantes na Espanha vem do Marrocos e as suas regras de identidade referem-se principalmente ao respeito a determinadas horas de descanso semanal, a certas restrições alimentares e ao emprego de alguns símbolos religiosos como o véu islâmico.

${ }^{206}$ CANAMARES ARRIBAS, Santiago. El empleo de simbología religiosa en Espana. Boletin Mexicano de Derecho Comparado, n. 116, v. 39, maio-agosto 2006, pp. 318-330. 
A Constituição espanhola reconhece o pluralismo em suas diversas formas como valor superior do ordenamento jurídico. Para que tal pluralismo possa existir, o Estado deve estar comprometido com a neutralidade. De acordo com o art. 16 da Constituição, o Estado não se reconhece nem privilegia nenhuma religião, nem direta nem indiretamente, mas adota um papel de garantidor que o faz retirar todos os obstáculos que impeçam a plena realização do direito de liberdade religiosa tanto dos indivíduos quanto de grupos.

Na questão do uso de símbolos religiosos surge o conflito entre a liberdade religiosa de um lado e a não confessionalidade do Estado de outro. Estes fatores levam a discutir a presença de símbolos religiosos em lugares públicos e a sua possível influência na liberdade de outros.

O artigo 16.1 da Constituição determina o direito à liberdade religiosa apenas com as restrições necessárias para garantia da ordem pública. Há também a Lei Orgânica de Liberdade Religiosa de 1980.

O Tribunal Constitucional em 2001 fala da liberdade externa pela qual as pessoas podem exercer todas as atividades que constituem manifestações da sua crença, sem possibilidade de coação pelo Estado.

A liberdade de manifestação por símbolos encontra como limite a ordem pública. O Tribunal Constitucional entende que a ordem pública é composta por princípios jurídicos, públicos e privados, políticos, morais e econômicos que são absolutamente obrigatórios para a conservação da ordem social em um povo e uma época determinada.

$\mathrm{Na}$ solução de casos envolvendo os símbolos religiosos, opina o autor espanhol, ser preciso analisar a circunstância concreta do caso, para determinar se a utilização de tais elementos corresponde verdadeiramente à satisfação de um preceito de conteúdo religioso. Para uma correta aplicação do princípio da proporcionalidade é preciso verificar se a manifestação da liberdade religiosa de fato viola outros direitos ou se há apenas mera hipótese de ameaças.

Para ilustrar a teoria, o autor cita caso ocorrida na Espanha, em que uma menina de 13 anos foi impedida de ir para a escola usando o véu islâmico. Alegava a escola particular que todos os seus alunos deveriam usar uniforme, o que seria incompatível com o véu islâmico. Enquanto se resolvia o impasse, a aluna foi transferida para uma escola pública. Contudo, a diretora entendeu que o véu era um instrumento de discriminação sexual, que deveria ser considerado inconstitucional. O Conselho de 
Educação entendeu que a menina deveria ser escolarizada sem qualquer condição, podendo assistir às aulas coberta com o véu.

O conflito existe de maneira mais clara nas escolas públicas em que seria possível vislumbrar um embate entre a liberdade religiosa e a neutralidade do Estado. Entende o autor espanhol que a neutralidade do Estado deve ser interpretada como um pressuposto para que a liberdade religiosa dos indivíduos seja exercida. A neutralidade não pode ser interpretada como uma forma de impedir manifestações de fé em ambientes públicos.

A liberdade religiosa poderá ser limitada pela laicidade do Estado quando o exercício do direito representar uma possível associação entre o Estado e uma confissão religiosa. No conflito analisado, a neutralidade do Estado restou incólume já que não seria possível imaginar que pelo fato de uma aluna num colégio público usar o véu islâmico, o Estado se identificaria com a religião muçulmana.

A Corte Europeia de Direitos Humanos julgou diversos casos envolvendo o véu islâmico.

Em 2001, a Corte, ${ }^{207}$ no já citado Dahlab v. Suíça, sancionou decisão de uma escola de proibir que uma professora portasse o véu islâmico durante as suas aulas, sob o argumento de que ela leciona para alunos de 4 a 8 anos, época em que as crianças são muito influenciáveis em comparação com alunos mais velhos. A proibição aqui parece bastante razoável, afinal professores, assim como outros funcionários públicos, no exercício de sua função representam o Estado e como tal não podem professar crenças religiosas que poderiam ser eventualmente identificadas com o Estado, que é laico. Diferente, contudo, é a discussão do uso de símbolos religiosos por cidadãos que frequentam prédios públicos.

Tratando do véu não em professores, mas sim em alunos, a Corte entendeu que a proibição imposta por uma Universidade de que os alunos portassem o véu no dia de prova não era abusiva, pois tinha base no direito turco, uma vez que a Corte Constitucional Turca já havia entendido que o uso do véu em Universidades era contrário à Constituição.

207 CORTE EUROPEIA DE DIREITOS HUMANOS - Dahlab v. Suíça (no 42393/98) - Julgado em 15/02/2001 - Disponível em: http://www.echr.coe.int/NR/rdonlyres/E0941C75-D511-487B-A99155A7074B5E59/0/FICHES_Liberté_religion_FR.pdf - Acesso em 11/05/2011 
Assim, a requerente, ao ingressar na universidade, tinha ciência da regulamentação acerca do uso do véu. ${ }^{208}$

A Corte considerou igualmente em acordo com o art. 9 da Declaração de Direitos Humanos a proibição de uso do véu em aulas de educação física, por razões de segurança e higiene. ${ }^{209}$ Também opinou por não abusiva a proibição de uso de símbolos ostensivos da religião muçulmana em escolas, pois tal decisão estava amparada pela legislação francesa. ${ }^{210}$

Pode-se perceber claramente uma tendência da Corte em não contrariar a legislação do país de onde surge a demanda, ainda que a atitude contestada seja claramente contrária à Convenção Europeia de Direitos Humanos. Não se consegue ver uma jurisprudência própria da Corte, tentando fazer valer os princípios inscritos na Convenção Europeia. Caberia, inclusive, discutir se teria a Corte competência para afastar a legislação própria do país que eventualmente confrontasse com a Convenção. Pelas decisões proferidas, não se consegue definir se a Corte concorda ou não com a legislação interna.

Já foi julgado pela Corte pedido de pessoa que se recusou a retirar o véu islâmico para se submeter a um controle de identidade no Consulado Geral da França em Marrakesh. A Corte não aceitou a demanda por entender que o controle de identidade faz parte de uma medida de segurança. ${ }^{211}$

Em rara decisão pela agressão ao art. 9 da Convenção, a Corte entendeu abusiva a condenação de 127 membros de um grupo religioso por andar em público com roupas típicas de sua religião. A Corte entendeu que os religiosos não ameaçaram a ordem pública e que este caso tratava-se de uso de vestimentas religiosas em locais abertos ao público e não em estabelecimentos públicos. ${ }^{212}$

\footnotetext{
${ }^{208}$ CORTE EUROPEIA DE DIREITOS HUMANOS - Leyla Sahin v. Turquia (n 44774/98) - Julgado em 10/11/2005 - Disponível em: http://www.echr.coe.int/NR/rdonlyres/E0941C75-D511-487B-A99155A7074B5E59/0/FICHES_Liberté_religion_FR.pdf - Acesso em 11/05/2011

${ }^{209}$ CORTE EUROPEIA DE DIREITOS HUMANOSDogru v. França (n. 27058/05) e Kervanci v. França (n. 31645/04) - Julgado em 04/12/2008 - Disponível em http://www.echr.coe.int/NR/rdonlyres/E0941C75D511-487B-A991- 55A7074B5E59/0/FICHES_Liberté_religion_FR.pdf - Acesso em 11/05/2011

${ }^{210}$ CORTE EUROPEIA DE DIREITOS HUMANOS - Aktas v. França (no 43563/08), Bayrak v. França (no 14308/08), Gamaleddyn v. França (no 18527/08), Ghazal v. França (no 29134/08), J. Singh v. França (no 25463/08) et R. Singh v. França (no 27561/08) - Julgado em 03/06/2009 - Disponível em http://www.echr.coe.int/NR/rdonlyres/E0941C75-D511-487B-A991-

55A7074B5E59/0/FICHES_Liberté_religion_FR.pdf - Acesso em 11/05/2011

${ }^{211}$ CORTE EUROPEIA DE DIREITOS HUMANOS - El Morsli v. França (no 15585/06) - Julgado em 04/03/2008 - Disponível em http://www.echr.coe.int/NR/rdonlyres/E0941C75-D511-487B-A99155A7074B5E59/0/FICHES_Liberté_religion_FR.pdf - Acesso em 11/05/2011

${ }^{212}$ CORTE EUROPEIA DE DIREITOS HUMANOS - Ahmet Arslaan e outros v. Turquia (n. 41135/98) Julgado em 23/02/2010 - Disponível em http://www.echr.coe.int/NR/rdonlyres/E0941C75-D511-487BA991-55A7074B5E59/0/FICHES_Liberté_religion_FR.pdf - Acesso em 11/05/2011
} 
O debate envolvendo o véu islâmico é o mais frequentemente visto na jurisprudência estrangeira, contudo, discussões semelhantes se apresentam com outros símbolos religiosos. Eis um caso ocorrido, nos EUA, ${ }^{213}$ com integrantes da religião Sikh que são obrigados a usar cinco símbolos de sua religião, sendo um deles uma faca.

Em 1994, um Distrito da Califórnia baniu todos os tipos de facas das escolas, sob pena de expulsão do aluno que a portasse. A mãe de três alunos que foram atingidos por esta proibição ingressou em Juízo para garantir o direito de seus filhos de frequentar a escola sem deixar de usar o símbolo sagrado para a sua religião. A decisão judicial permitiu o retorno dos alunos para a escola com a possibilidade de portar o símbolo característico de sua religião. Para esta decisão foi determinante o Religious Freedom Restoration Act (RFRA), ao prescrever que ação estatal não pode agredir a liberdade de religião, a não ser que a sua ação seja a mais restritiva possível.

A questão do porte de símbolos religiosos de quaisquer tipos recai sempre no mesmo ponto, qual seja, a existência de um eventual conflito entre a neutralidade estatal e a liberdade religiosa dos cidadãos. Analisando-se os casos existentes na jurisprudência, parece bastante temerária a tentativa de solucionar o conflito por via legislativa. Em se tratando de direitos fundamentais, a adoção de soluções genéricas que estabeleçam de maneira peremptória a restrição de um direito fundamental em detrimento de outro deve ser evitada por sociedades democráticas.

Não há que se questionar o caráter relativo de direitos e princípios fundamentais, contudo, é assente que a sua restrição depende de rigorosa e cuidadosa análise do caso concreto, a fim de que seja resguardada a excepcionalidade e proporcionalidade da medida restritiva.

Parece não haver meio razoável de se determinar a priori se o porte de símbolos religiosos deve ou não ser sempre permitido em espaços públicos. Tratando-se de uma expressão da liberdade religiosa, a regra para o porte símbolos tende a ser a permissão. É de se esperar que Estados de Direito prefiram ter como regra a liberdade e como exceção a proibição. Por óbvio que o porte de símbolos que fira outros direitos fundamentais ou que cause transtornos à ordem pública pode vir a sofrer uma restrição. Esta restrição, porém, teria um caráter excepcional, justificado em razão do interesse

${ }^{213}$ LECHLITER, Michael E. The free exercise of religion and public schools: the implications of hybrid rights on the religious upbringing of children. Michigan Law Review, August 2005. vol. 103, n. 8, pp. 22092210. 
público ou para garantir a prevalência de outro direito fundamental eventualmente em conflito.

Neste sentido entende Pierre Caps, ${ }^{214}$ ao afirmar que a liberdade de consciência assim reconhecida aos estudantes não pode resultar em um atentado, nem ao pluralismo e à liberdade dos outros, nem ao conteúdo dos programas e à obrigação de assiduidade. Consequentemente, o porte pelos alunos de símbolos religiosos na escola, "não é incompatível com o princípio da laicidade, na medida em que ele constitui o exercício da liberdade de expressão e de manifestação de crenças religiosas", sob a condição de não parecer um ato de proselitismo ferindo o bom desenvolvimento do serviço público de ensino.

Neste ponto, é fundamental lembrar que a laicidade do Estado trata-se de mais uma forma de garantir a liberdade religiosa dos cidadãos. Afinal, o Estado que não adota uma religião não discrimina nem privilegia nenhum tipo de crença, garantindo uma igualdade de tratamento a todos os cidadãos que creiam em qualquer tipo de religião. A laicidade estatal deve ser um instrumento de garantia da liberdade religiosa dos cidadãos e nunca uma forma de proscrever a religião da vida das pessoas.

Somente o Estado tem dever de neutralidade, os indivíduos não. A alegação de que o uso de símbolos religiosos pelos cidadãos em espaços públicos deva merecer tratamento diferenciado não tem qualquer fundamento. $\mathrm{O}$ motivo para a restrição do porte de símbolos religiosos em qualquer lugar deve ser a existência de uma agressão a demais direitos fundamentais e não o lugar em que a expressão da crença ocorre. $\mathrm{O}$ mero fato de um cidadão portar símbolos religiosos em lugares públicos não é suficiente para autorizar a sua proibição.

Diferente é o caso, já analisado, de funcionários do Estado, como professores de escola pública, que na qualidade de representantes do Estado devem manter-se neutros frente às opções religiosas uma vez que eles são responsáveis por representar a vontade estatal. O uso de símbolos religiosos por professores é temerária, pois além de identificar o Estado a uma religião, pode vir a influenciar os alunos na crença de uma religião específica.

${ }^{214}$ PIERRE CAPS, 1990, p. 1084. 


\section{III.4.2- Símbolos religiosos e prédios públicos}

A questão dos símbolos religiosos não se desdobra apenas na possibilidade de serem portados por alunos ou professores em escolas públicas (ou por agentes públicos no exercício de suas funções), mas também refere-se à permissão para que eles sejam colocados em prédios públicos. Tal questão gera alguma controvérsia no Brasil, dada a existência de crucifixos em diversos prédios públicos, como Tribunais e órgãos do Poder Legislativo.

No Brasil, sobre esta questão ficou bastante conhecido o mandado de segurança ${ }^{215}$ impetrado contra ato do Presidente da Assembleia Legislativa de São Paulo que retirou o crucifixo que estava fixado no Plenário da Assembleia. O Tribunal de Justiça de São Paulo entendeu por maioria que a presença do crucifixo no plenário seria um símbolo espiritual universal pertencente ao patrimônio público. Não haveria, com isso, ofensa à Constituição, pois é ela própria quem incentiva o ato religioso. A imagem de Cristo não causaria prejuízo político, pelo contrário promoveria a concórdia. Entendem os desembargadores que a invocação de Deus no preâmbulo da Constituição demonstraria uma clara opção religiosa do constituinte. Além do que, haveria ainda o valor material do metal de que é feita a imagem de Cristo.

Ainda sobre a possibilidade de prédios públicos ostentarem imagens religiosas, podemos citar a decisão do Conselho Nacional de Justiça ${ }^{216}$, que entendeu ser válida a existência de tais símbolos. O requerente pretendia a retirada de crucifixos dos Tribunais de Justiça do Ceará, de Santa Catarina e de Minas Gerais e do Tribunal Regional Federal da $4^{\text {a }}$ Região. Para tanto invocava os seguintes argumentos: a laicidade do Estado (art. 19, I da CF/88); o crucifixo sugere o respeito a princípios que estariam acima dos símbolos e valores nacionais; os servidores parecerem estar submetidos a princípios que não os da Administração Pública; apoio de amplo espectro da sociedade, que não é sectarista, para a retirada dos símbolos.

O Tribunal de Justiça do Ceará alegou que o crucifixo estaria lá há anos. O TJ-MG sustentou o valor histórico das peças e o TRF da $4^{\mathrm{a}}$ Região afirmou a ausência de significado religioso do símbolo.

O Conselheiro Paulo Lobo, primeiro a apreciar a matéria, decidiu submeter o caso ao Plenário por entender que poderia haver duas posições possíveis: o crucifixo não

\footnotetext{
${ }^{215}$ TJ/SP - MS 13.405-0 - Rel. Desembargador Rebouças de Carvalho - Julgado em 02/10/1991.

${ }^{216}$ CNJ - Pedidos de Providência 1344, 1345, 1346, 1362 - Rel. Oscar Argollo - Julgado em 21/06/2007.
} 
representa nenhum valor religioso, mas apenas tem um caráter cultural ou; representa a escolha por uma religião de modo a ferir o princípio do Estado Laico.

O Conselheiro Oscar Argollo, no que é seguido pela maioria dos Conselheiros, entende válida a permanência dos crucifixos nos referidos Tribunais. Entende existirem dois tipos de interesse público: primário (sociedade) e secundário (pessoas jurídicas de direito público). Manter um crucifixo numa sala de audiência não torna o Estado, nem o Poder Judiciário, clerical. O símbolo não ofende o interesse público primário (sociedade).

Não há no ordenamento jurídico nenhuma proibição à colocação de tais símbolos, que são tradicionais na cultura brasileira. "O costume de expor, eventualmente, em dependências ou ambiente de órgãos públicos a imagem de um crucifixo corresponde, sem embargos, a uma necessidade jurídica, de acordo com as homenagens devidas à Justiça." O Estado não tem o direito de se imiscuir nas tradições da sociedade. Além do que, o Judiciário tem autonomia administrativa e o símbolo não fere a liberdade religiosa de ninguém.

$\mathrm{Na}$ França, a colocação de tais símbolos é proibida em monumentos públicos fora dos terrenos de sepultura, de monumentos funerários, de museus e exposições. A restauração de um monumento erigido antes da lei de separação não é proibida, nem o depósito de cruz ou emblema religioso erigido em praça pública em homenagem a mortos de guerra. ${ }^{217}$

A discussão de fixação, principalmente, de crucifixos em prédios públicos é bastante comum em países de tradição católica.

De acordo com Elisa Olivito, ${ }^{218}$ o crucifixo é visto como um símbolo dotado de significado não apenas para uma pessoa, mas para toda uma civilização e para a cultura cristã em sua raiz histórica. Seria, assim, um valor universal, independentemente de uma concepção religiosa específica.

Tal tipo de visão desafiou a versão rígida da laicidade, levando-se a entender que o princípio da laicidade não impõe uma separação entre as questões civis e as religiosas, mas impõe o reconhecimento de igual dignidade entre as diversas opções religiosas. A questão que se coloca é que o Estado laico baseia-se na neutralidade e a colocação de símbolos religiosos de uma só religião parece ferir tal fundamento.

${ }^{217}$ COLLIARD, 1979, p. 351.

${ }^{218}$ OLIVITO, 2004, p. 554-64. 
Há pronunciamento em diversos países sobre a questão. O Tribunal Suíço entendeu que a ostentação do símbolo em escolas públicas demonstraria uma identificação do Estado com uma religião específica e poderia induzir os alunos a crer naquela religião. Além de representar uma ofensa à liberdade religiosa dos alunos que teriam uma religião imposta pelo Estado.

O Tribunal Constitucional Alemão, por sua vez, refere-se à necessidade de equilíbrio entre a liberdade positiva dos católicos e a liberdade negativa dos não católicos. Os alunos não são obrigados a se confrontar com um símbolo religioso. E a liberdade religiosa negativa envolve a garantia de fazer com que os não crentes mantenham-se longe de símbolos representativos de uma religião.

Esta concepção, segundo a autora, traz à tona a concepção de separação total, pois deixa de considerar a importância social e histórica da religião. O Estado italiano sempre foi caracterizado por um pluralismo religioso e isso deve ser respeitado pelo Estado laico. Contudo, a laicidade envolve a proteção igual de todas as religiões e neste ponto há um nítido limite ao pluralismo. A exteriorização de um valor religioso não deve ser permitida quando ela significa uma imposição e quando há apoio do Estado.

A despeito de se reconhecer a importância do cristianismo para a sociedade italiana, não se poderia entender que o crucifixo tem um valor universal. Ademais, a história italiana não se reduziria apenas ao cristianismo.

Acreditar que o crucifixo tem um significado histórico e universal é uma concepção parcial, característica do mundo ocidental que tem a tendência de achar que as suas concepções são únicas. Este tipo de crença faz esquecer a relatividade das crenças. $\mathrm{O}$ princípio da laicidade deve criar um ambiente favorável ao pluralismo e não impedir seu crescimento.

O pluralismo religioso como objetivo primordial da laicidade estatal também é ressaltado por outros autores ${ }^{219}$, em que se enxerga a neutralidade como uma proibição de não discriminação, expoente do princípio da igualdade. A ligação entre um símbolo e um aspecto religioso contraria o centro da luta contra as discriminações fundadas sobre a aparência, verdadeira ou suposta, a uma etnia, nação ou uma raça, suas opiniões políticas, suas convicções religiosas, sua aparência física. A designação de um sinal ou de uma insígnia como expondo uma aparência religiosa mais do que uma crença pessoal induz o crescimento de comunitarismo contra a qual a lei pretende lutar.

${ }^{219}$ KOUBI, Geneviève. Vers une déconstruction du príncipe de laïcité? Revue Du Droit Public de La Science Politique en France et à l'Étranger. Paris, LGDJ, n. 2, 2004, p. 327. 
Em países de forte tradição católica, pode-se vislumbrar uma clara predileção em manter crucifixos e demais símbolos católicos em prédios públicos, sem considerar a existência de uma eventual agressão à laicidade estatal.

$\mathrm{Na}$ Espanha, como esperado, a existência de crucifixo em prédios públicos já gerou discussões. Canamares Arribas ${ }^{220}$ trata de diversas passagens em que se enfrentou a problemática de símbolos fixados em lugares públicos. A Direção Provincial do Ministério da Educação e Cultura, sendo provocada por uma associação de pais de alunos, entendeu correta a presença de crucifixos em ambientes escolares Por fim, levou-se a questão ao TSJ que não discutiu a matéria de fundo da ação, mas apenas colocou nas mãos da Administração a decisão sobre manter os crucifixos ou retirá-los (TSJ de Madrid, Sentença de 15/10/02).

O autor também cita outro episódio em que uma Associação defensora de uma educação pública e laica soltou um informe defendendo que o não confessionalismo não pressupõe nem ignorância nem desconhecimento, por parte do Poder Público, da crença dos seus cidadãos. Assim, a presença do crucifixo representaria apenas o reconhecimento de uma realidade social inegável que é a religiosidade dos cidadãos espanhóis. Não se poderia dizer que há um desrespeito à neutralidade do Estado simplesmente pelo fato de existirem crucifixos em escolas públicas.

No que diz respeito à agressão a liberdade religiosa dos alunos, o informe trata de duas situações. A primeira diz respeito a crucifixos em lugares destinados ao culto e a segunda a crucifixos em salas de aula.

O primeiro caso envolveria uma obrigação disposta na Lei Orgânica de Liberdade Religiosa e em nada feriria a liberdade religiosa dos alunos, pois não haveria qualquer obrigação de que eles frequentassem tais lugares.

Por sua vez, colocar na parede de uma sala de aula um crucifixo seria ato que atingiria todas as pessoas que frequentarem a sala sem fazer qualquer diferenciação entre sua religião. Assim, sua presença deveria ser considerada inconstitucional por ferir a liberdade religiosa dos não católicos.

A identificação do crucifixo como um símbolo religioso não deveria ser imediata uma vez que seu significado passaria também por questões culturais, históricas e de transmissões de valores culturais. Esta ideia foi acolhida pelo Tribunal Supremo em

${ }^{220}$ CANAMARES ARRIBAS, 2006, pp. 338-347. 
25/03/93. Antes de determinar se um crucifixo viola a liberdade religiosa das pessoas, seria preciso verificar se inequivocamente tratar-se de um símbolo religioso.

Segue o autor, elencando debates em torno do tema. Questão interessante surgiu na Universidade de Valencia, em que se pretendia suprimir a imagem da Virgem Maria do escudo e da medalha da Universidade. O Tribunal Supremo (12/06/90) entendeu que a supressão da imagem não poderia ser justificada na laicidade do Estado. O Tribunal entendeu que a laicidade do Estado nada tem a ver com a imagem religiosa no brasão da Universidade, que existe desde 1771, sendo algo tradicional da Universidade.

O Tribunal Constitucional em 06/06/91 assinalou que a vigência do princípio da laicidade não obriga a Universidade a retirar a imagem, já que é o respeito à história e às tradições que leva as autoridades acadêmicas a manter a imagem religiosa no escudo universitário.

A questão dos símbolos religiosos também surgiu em âmbito judicial, em que os contraentes de um matrimônio requereram a retirada do crucifixo que ficava na sala de audiência onde iria ocorrer o matrimônio. A Direção Geral de Registros e Notariado declarou-se incompetente para decidir a questão.

Sobre esta questão é importante trazer a teoria elaborada pelos Tribunais que analisa a legitimidade de algumas instituições que tiveram origem religiosa, mas que com o tempo acabaram se secularizando, adquirindo conotações culturais e civis, sendo apenas subsidiariamente religiosas.

Um dos exemplos mais claros de instituições que tiveram origem religiosa e que se secularizaram foi o descanso semanal aos domingos. Tal foi o entendimento do Tribunal Constitucional, em sentença de 13/02/85, deixando claro que o domingo como dia de descanso semanal perdeu seu caráter religioso, tendo atualmente se tornado uma instituição laboral e secular.

O mesmo poderia ser dito de alguns símbolos religiosos em espaços públicos. Mais do que uma conotação religiosa, tais símbolos apresentam valores culturais e sociais que raramente podem representar uma ofensa à neutralidade do Estado.

Conclui o autor que devem ser rechaçadas as determinações abstratas que tentam resolver os conflitos que envolvem a liberdade religiosa. A lei francesa aprovada em 14 de março de 2004 enuncia uma norma tão rígida que impede que sejam considerados os diferentes perfis e circunstâncias que determinam uma realidade específica. Com este tipo de solução abstrata corre-se o risco de infligir uma excessiva 
restrição à liberdade religiosa, que ultrapasse inclusive o limite da necessidade de garantia do interesse público.

Vale lembrar a Recomendação 1202/1993 do Conselho da Europa de que o princípio da laicidade deve ser empregado em favor do homem, devendo ser colocado o indivíduo em primeiro lugar. Assim, a liberdade religiosa deve condicionar a laicidade do Estado.

Interessante citar caso ocorrido na Itália que culminou em julgamento pela Corte Europeia de Direitos Humanos ${ }^{221}$. Uma senhora, cujos filhos estudavam numa escola pública na qual havia crucifixos nas paredes de todas as salas de aulas, dirigiu-se inicialmente ao Conselho da Escola para manifestar sua objeção à presença dos crucifixos uma vez que eles eram contrários ao princípio da laicidade, pelo qual ela pretendia educar seus filhos. O conselho da escola decidiu manter o crucifixo. Contra tal decisão dirigiu-se a requerente ao Tribunal Administrativo, que entendeu a presença dos crucifixos como de acordo com o princípio da laicidade.

A questão foi julgada primeiramente pela Segunda Seção da Corte Europeia. Para fundamentar a sua decisão, a Corte relembra princípios por ela definidos em julgamentos anteriores. O primeiro refere-se ao direito fundamental à educação que envolve a necessidade de as convicções religiosas e filosóficas dos pais serem respeitadas quer em escolas públicas quer em particulares. O respeito a tais convicções no ambiente escolar deve promover a inclusão de pensamentos diferentes e jamais a sua exclusão. A escola não pode ser ambiente de pregação ou de atividades missionárias, mas sim um ponto de encontro entre todas as religiões e convicções filosóficas.

Caberia ao Estado, assim, garantir este ambiente de harmonia entre as ideias, impedindo que sejam propagadas concepções impositivas de uma única linha de pensamento. O respeito às convicções dos pais e dos alunos no ensino implica o reconhecimento do direito de acreditar em uma religião ou de não acreditar em nada.

Baseada nestas considerações, a Corte entende que cabe ao Estado refrear a imposição de valores que ocorram, ainda que por meios indiretos, principalmente em lugares frequentados por pessoas dependentes ou vulneráveis. A Corte precisa considerar se, no caso em análise, o Estado ao permitir o crucifixo na sala de aula, o fez de maneira objetiva e imparcial.

${ }^{221}$ CORTE EUROPEIA DE DIREITOS HUMANOS - Lautsi e outros v. Itália (n. 30814/06) - Julgado em 18/03/2011 - Disponível em http://www.echr.coe.int/NR/rdonlyres/E0941C75-D511-487B-A99155A7074B5E59/0/FICHES_Liberté_religion_FR.pdf - Acesso em 11/05/2011 
O Governo italiano sustenta a imposição do crucifixo dá-se em razão dos valores morais defendidos pelo cristianismo que estão de acordo com valores constitucionais seculares. Sustenta ainda a importância histórica da Igreja Católica na história italiana.

A Corte, contudo, entende que apesar de o crucifixo ter significados outros que não o religioso, este é predominante. A fixação de crucifixos em escolas ultrapassaria, assim, a exposição de símbolos históricos.

O emprego de crucifixos em ambientes escolares poderia fazer com que os alunos acreditassem que a escola implica um ambiente ligado à religião. Ainda que para alguns alunos a presença religiosa (católica) possa ser reconfortante, para outros pode ser perturbadora, principalmente se eles são parte integrante de uma religião minoritária ou se não têm religião alguma.

A presença do crucifixo, portanto, não auxilia, pelo contrário dificulta, a criação de um ambiente pluralista, que é o verdadeiro objetivo da escola. A imposição do crucifixo afronta os preceitos inscritos no artigo 9 da Convenção.

Quando submetido o julgamento à Grande Câmara, a decisão foi radicalmente oposta. A Corte entendeu que a colocação de crucifixos não violaria nem o direito à instrução nem o direito à liberdade religiosa. Mesmo que o crucifixo seja símbolo representativo da religião dominante no país, a sua mera presença não seria responsável por representar uma forma de doutrinação. Não havendo consenso sobre o uso de crucifixos sequer entre os países europeus, a sua regulamentação deveria caber à legislação interna de cada país.

Ademais, a mera presença do crucifixo, no entender da Corte, não demonstraria que o Estado apoia a religião católica e que seria refratário aos alunos que professassem crença diversa.

A Corte Suprema dos EUA estabeleceu uma diferença entre símbolos religiosos ativos e passivos (Lynch $v$. Donnely). Entendeu-se que um presépio ou uma representação natalina não ferem o Establishment Clause, sendo símbolos passivos, diferentemente de um coral ou de uma procissão em que há coparticipação das pessoas. ${ }^{222}$

A caracterização de um símbolo como ativo depende muito do local em que é colocado. Um crucifixo numa escola ou numa sala de audiência demonstraria uma 
identificação entre aquilo que é ensinado na escola com a verdade divina, bem como com a justiça divina.

A Suprema Corte dos EUA, em sua história, demonstrou várias interpretações diferentes sobre como resolver o conflito entre a liberdade religiosa e a neutralidade estatal.

Michael Lechliter ${ }^{223}$ descreve esta mudança de opinião. Em Yoder, a Corte entendia que mesmo uma lei genérica poderia ferir a liberdade religiosa. Assim, leis gerais as vezes deveriam ceder frente a direito individuais.

Em Smith, Justice Scalia refuta vários posicionamentos assumidos em Yoder, entendendo haver no caso uma situação híbrida em que os direitos dos pais e o direito de livre exercício apresentavam o mesmo status. A Corte passa a falar em exceção dos direitos híbridos, mas não determina como agir. Em resposta a este julgamento, o Congresso aprova a legislação do RFRA que pretende compelir os Estados a conceder exceções religiosas em leis de aplicação geral. Seria um retorno à jurisprudência anterior a Smith.

A legislação do RFRA acabou não tendo grande aceitação entre os Estados americanos que acabaram editando versões próprias da lei. Assim, em muitos lugares levar assuntos de exceção a leis genéricas relativas à religião acabou se tornando difícil. Além do argumento da Free Exercise Clause, quem pretendesse objetar judicialmente disposição contida em lei genérica, poderia alegar o direito de educação religiosa de seus filhos.

Argumenta o autor que os pais têm um direito fundamental sob a Constituição dos EUA de dirigir a educação religiosa de seus filhos.

A preocupação da Corte em permitir exceções à lei geral é conceder uma autorização para que todos possam descumprir a lei de maneira individual. Por Smith, a Corte entende que cabe ao processo legislativo e não às Cortes determinar a garantia à liberdade de religião.

Por Yoder, fica claro que qualquer interesse dos pais em direcionar a educação dos filhos, sem qualquer fundamento religioso não será suficiente para criar uma exceção.

Os pais teriam direito a controlar a educação religiosa dos filhos, mesmo em face da educação pública. A cláusula de livre exercício merece ainda maior proteção quando a religião atua juntamente com o direito dos pais.

$\overline{{ }^{223} \text { LECHLITER, 2005, pp. 2211-2238. }}$ 
Em Smith, a Corte reconhece que os direitos individuais não podem ser entendidos sem qualquer contexto, mas devem se relacionar.

Em Brown vs. Hot, Sexy \& Safer Products Inc., dois estudantes do ensino médio e seus pais processaram os diretores de um programa de prevenção da AIDS e o comitê escolar por uma campanha ofensiva. Com respeito à demanda híbrida, a Corte lembrou primeiro do direito de educar seus filhos, mas também questionou se este direito dos pais era fundamental. Tal questão atualmente se encontra encerrada com uma resposta afirmativa. Conclui-se que apesar da existência de um direito dos pais de educar seus filhos, tal direito não poderia ser amplo o suficiente para alterar o programa de toda uma escola.

É bastante comum o conflito entre religião e educação. Frequentemente, o ensino em escolas públicas vai ferir concepções de minorias religiosas. Não podendo os pais pagar uma escola particular, em que poderiam escolher a doutrina adotada pela escola, há um risco bastante grande de suas concepções religiosas serem atingidas pelas regras adotadas pela escola pública.

Tome-se como exemplo o caso de aluna muçulmana que sempre frequentou a escola usando o véu islâmico. Após o 11 de setembro, contudo, a aluna foi proibida de frequentar a escola com o véu. Os pais se recusaram a cumprir a ordem e a aluna foi suspensa. Os advogados da escola avisaram aos pais que a aluna não poderia voltar a frequentar a escola enquanto mantivesse o véu. Segundo eles, a escola estava adotando uma política para a redução das gangues e havia proibido o uso de adornos na cabeça. Aqui, força-se a uma escolha. Ou a aluna permanece na escola ou ela segue a sua religião. As duas atividades não poderiam ser conciliadas.

A melhor solução para o caso seria manter incólume a política escolar, reconhecendo, porém, que o caso da aluna muçulmana representa uma exceção religiosa. Agora se a teoria de Smith fosse adotada integralmente, caso se entendesse que a lei que proibiu o uso de adornos na cabeça não tivesse motivação religiosa, nenhuma exceção seria permitida. Tal conclusão é profundamente ilógica.

Para o reconhecimento de exceções, é interessante lembrar o caso O’Brien em que se discutia uma restrição à sua liberdade de expressão. O’Brien para expressar sua revolta queimou o seu draft card. Para discutir se esta manifestação seria válida, considerou-se a possibilidade de a pessoa expressar a sua ideia por diversos meios. E como tal possibilidade existe, a pessoa poderia ter se expressado de maneira menos ofensiva. No 
caso da aluna muçulmana, ela não tem outra escolha para professar a sua fé. Ou ela usa o véu ou deixa de receber educação pública.

Em Yoder, a Corte decidiu a favor dos direitos religiosos, pois o Estado não conseguiu provar como abrir uma exceção religiosa impediria o ensino público.

Outro assunto apontado por autores ${ }^{224}$ como importante na jurisprudência dos EUA é a discussão do juramento religioso (pledge of allegiance). Recitar que a Nação está "under God" demonstra claramente um propósito religioso. Contudo, quem defende essa expressão tende a negar seu caráter religioso e levar tal declaração para um caráter histórico e tradicional.

A interpretação secular do governo do juramento de fidelidade foi, sob a visão de alguns, uma mentira educada contada somente para a Corte. Ultrapassando a questão de que o "under God" seria uma mentira, entende-se que todas as religiões estão envolvidas nesta afirmação, ficando excluídos apenas os ateus e agnósticos. A Corte não chegou a analisar o mérito do caso, mas alguns Juízes discorreram sobre a matéria.

O’Connor e Rehnquist entendem que o juramento é secular e não diz respeito a sentimentos religiosos. O'Connor fornece alguns elementos que podem identificar afirmações religiosas que tenham um sentido secular. Tal reconhecimento secular exigiria um entendimento comum do propósito secular, que somente poderia existir quando determinada prática tem um significado para grande parte da população. Outro elemento seria a falta de oração ou adoração. $O$ terceiro elemento diz respeito a não existir uma referência a uma religião em particular. Esse fator proíbe a referência a qualquer Deus em particular ou a Jesus. Seria impossível uma referência genérica que abarcasse todas as religiões, mas a palavra Deus chega o mais perto possível desta generalidade. O quarto fator é o menor conteúdo religioso possível. A brevidade da referência religiosa tende a confirmar o propósito secular.

$\mathrm{O}$ autor entende que essa interpretação fere tanto as pessoas que têm uma religião quanto aquelas que não creem em nenhuma. Seria muito mais coerente aceitar que a expressão tem sim um significado religioso, mas que é tão inofensivo que poderia ser aceito para propósitos seculares.

Justice O'Connor ainda coloca um quinto elemento segundo o qual o governo não poderia obrigar ninguém a participar de um ato de um cerimonial deísta. West

${ }^{224}$ LAYCOCK, 2004, p. 224-241. 
Virginia v. Barnette ainda está válido. Tal julgado estabelece que ninguém será obrigado a dizer a parte do juramento que tenha algum significado religioso.

Em Marsh v. Chambers, a oração na abertura da sessão legislativa é permitida em razão da tradição. Faz-se referência, inclusive, à tradição que vem se repetindo desde o $1^{\circ}$ Congresso.

Justice Rehnquist argumenta que o juramento é secular, mais patriota do que religioso. Ele argumenta que durante a história sempre houve manifestações religiosas pelos presidentes americanos. Tais demonstrações, contudo, enquadram-se mais na liberdade de expressão do que no caráter laico do Estado.

Dworkin $^{225}$ também se preocupa em analisar a menção a Deus em juramentos coletivos. Relembra o autor que antes mesmo de a referência a Deus fazer parte do juramento, a Suprema Corte entendeu que ele não poderia ser tomado como obrigatório para alunos em escolas públicas.

Segundo o autor, os defensores do juramento acreditam que ele simboliza uma indispensável fusão entre religião e patriotismo. Como ninguém pode ser obrigado a recitar o juramento não estaria sendo obrigado a praticar qualquer ato que contrarie a sua consciência. Contudo, a não obrigatoriedade não é suficiente para respeitar a dignidade humana. Não faz sentido o governo criar um juramento que faça com que seus cidadãos se sintam discriminados. A única justificativa para tal imposição é uma concepção pessoal de que religião e patriotismo devem se confundir.

A força coercitiva, contudo, da imposição do juramento não é socialmente relevante. Apesar de ser uma violação à liberdade, ela não é uma violação grave. A tentativa de tornar o juramento religioso, segundo o autor, falhou, o que não significa dizer que tal pretensão seja legítima. De relevância reduzida também teriam as discussões sobre demonstrações públicas de ícones religiosos, tais como árvores de Natal.

A Corte Europeia de Direitos Humanos já expressou opinião diferente da Suprema Corte Americana sobre a possibilidade de prestar juramento sobre o Evangelho no Parlamento. A Corte ${ }^{226}$ entende que o juramento religioso não pode ser uma obrigação numa sociedade democrática. Seria contraditório submeter o exercício de um mandato que

\footnotetext{
${ }^{225}$ DWORKIN, Ronald. Is democracy possible here? Principles for a new political debate. Princeton: Princeton University Press, 2006, p. 84-6.

${ }^{226}$ CORTE EUROPEIA DE DIREITOS HUMANOS - Buscarini e outros v. Saint-Marin (n. 24645/94) Julgado em 18/02/1999 - Disponível em http://www.echr.coe.int/NR/rdonlyres/E0941C75-D511-487BA991-55A7074B5E59/0/FICHES_Liberté_religion_FR.pdf - Acesso em 11/05/2011
} 
pretende representar no seio do Parlamento diferentes visões da sociedade à condição de aderir a uma visão específica de mundo através do juramento.

Referindo-se, ainda, à questão do porte de símbolos religiosos, outra problemática está na sua relação com documentos oficiais. Em Sinan Isik v. Turquia ${ }^{227}$, a Corte Europeia de Direitos Humanos decidiu pela possibilidade de o campo "religião" no documento de identidade permanecer em branco.

Este tema em particular serve como um bom indicativo para evidenciar o verdadeiro caráter da relação entre o Estado e uma determinada religião. Mesmo em Estados ditos laicos, a existência de símbolos religiosos em prédios públicos tem o condão de revelar uma ligação especial, ainda que não reconhecida oficialmente, do Estado com a religião dominante no país.

Antes de pensar numa solução para este problema, enfrentado por diversos Estados, é interessante lembrar a definição trazida por Dworkin e já citada em capítulo anterior de Estado religioso tolerante e de Estado secular tolerante.

Em ambos, a liberdade religiosa é reconhecida e garantida, mas no Estado religioso há um reconhecimento oficial da importância da religião na vida da sociedade. Diferentemente do Estado secular, o religioso permite manifestações claramente ligadas a Deus e a uma religião por parte do Estado, tais como a ostentação de símbolos religiosos em prédios públicos.

Ao tratar da questão da laicidade do Estado, costuma-se entender que a separação rígida e absoluta entre Estado e religião seria a única forma eficiente de garantir a liberdade religiosa numa democracia. A influência da religião sobre o Estado não significa, contudo, uma intolerância com as demais religiões.

Para debater todas as consequências da consagração da liberdade religiosa, é preciso esquecer a ideia aparentemente preconceituosa de que qualquer tipo de relação entre Estado e Igreja seria perniciosa à tolerância e à liberdade religiosas.

A manutenção ou não de símbolos religiosos em prédios públicos é um assunto que costuma ser tratado de modo a tentar esconder a existência de uma verdadeira influência religiosa. Os Estados que aceitam a permanência de tais símbolos, e eles são maioria no mundo ocidental, têm trazido como justificativa para tanto a inexistência de caráter religioso em crucifixos e outros símbolos.

${ }^{227}$ CORTE EUROPEIA DE DIREITOS HUMANOS - Sinan Isik v. Turquie (n. 21924/05) - Julgado em 02/02/2010 - Disponível em http://www.echr.coe.int/NR/rdonlyres/E0941C75-D511-487B-A99155A7074B5E59/0/FICHES_Liberté_religion_FR.pdf - Acesso em 11/05/2011. 
Ora, parece difícil acreditar que um crucifixo na parede de um Tribunal não tenha claro apelo à religião católica. Insiste-se, contudo, em utilizar tal argumento, pela dificuldade que os órgãos públicos têm em assumir que sofrem influência de uma determinada religião, mas que mesmo assim respeitam a plena liberdade religiosa. Ao se tomar uma decisão a favor de uma religião, paira sempre o receio de a decisão parecer contrária ao tão afamado princípio da laicidade e acabar jogando o Estado, ainda que nominalmente, na vala dos Estados religiosos intolerantes.

Da mesma forma que o apoio de um Estado a uma religião não significa automaticamente intolerância religiosa, a laicidade pura não garante plena liberdade de consciência. Para todos os Estados que permitem a manutenção de símbolos religiosos em prédios públicos, seria mais coerente assumir a influência de uma determinada religião, sem prejuízo da tolerância religiosa, do que tentar argumentar o impossível, ou seja, de que um símbolo claramente religioso perdeu tal caráter, restando apenas a conotação histórica.

A diferença entre Estado religioso e secular pode ser compreendida como gradações de Estados laicos. Pode um Estado invocar Deus em seus pronunciamentos e assumir símbolos religiosos sem que com isso cause lesões irreversíveis ao princípio da laicidade. Óbvio que se estaria falando de uma laicidade atenuada, mas ainda laicidade, pois o Estado não teria uma religião oficial, nem subvencionaria uma religião em detrimento de outras.

É preciso ter em mente que a separação rígida não é sinônimo de tolerância religiosa. Afinal, a laicidade levada ao extremo pode resultar em hostilidade às religiões, criando um ambiente de profunda intolerância, como se vislumbra na França com a lei do véu.

Independentemente da posição, a favor ou contra a influência da religião, é forçoso tentar reconhecer a verdadeira realidade de cada Estado. Não basta enunciar o Estado como laico, é preciso ir além e detectar se se trata de um Estado com influências religiosas ou puramente secular.

A resposta a tal indagação já soluciona grande parte da problemática envolvendo não só os símbolos religiosos, mas outras questões atinentes à religião. Considerando-se o Estado como secular, nenhum tipo de influência religiosa há de ser admitida. Neste caso, a solução é fácil e óbvia. Os símbolos religiosos devem ser proscritos de prédios públicos. 
Já, pelo contrário, sendo o Estado religioso e tolerante, a resposta não é óbvia. Abre-se, então, a possibilidade de os símbolos religiosos serem permitidos. Resta saber quais os fatores que devem considerados para a decisão.

Um Estado mesmo religioso, mas que se pretenda tolerante, não pode admitir manifestações religiosas que sejam agressivas à liberdade dos crentes em outras religiões e dos não crentes. Deve-se discutir a relevância social do símbolo religioso e seu potencial para gerar conflitos religiosos e ofensas àqueles que não concordam com a sua presença em locais públicos.

Entendendo-se que a presença do símbolo não gera perturbações à ordem pública, a justificativa para a sua permissão seria o próprio conceito de Estado religioso tolerante, sem que para tanto fossem necessários malabarismos teóricos para provar que um símbolo religioso não é religioso.

Pela análise do quadro constitucional e da história brasileiros, é bastante razoável concluir-se que o nosso Estado apresenta maior vocação para ser um Estado religioso tolerante, do que secular. A invocação de Deus no preâmbulo da Constituição já é motivo suficiente para se confirmar a afirmação precedente. As próprias decisões do Judiciário no sentido da permanência de símbolos religiosos em prédios públicos é indicativo da mesma conclusão.

Claro que a definição de um Estado como religioso ou secular não deve ser vista como imutável historicamente. Alterados os anseios da sociedade, pode-se muito bem migrar de um Estado religioso para secular e de secular para tolerante. O que deve remanescer sempre como imutável é a batalha pelo reconhecimento e garantia de ampla liberdade religiosa, não importando o regime de separação entre Estado e Igreja.

\section{III.5- Transfusão de sangue em Testemunhas de Jeová}

A questão da transfusão de sangue resume-se na possibilidade (ou não) de o Estado obrigar a que Testemunhas de Jeová recebam transfusões de sangue, ato que é proibido por quem professa tal religião.

A possibilidade de testemunhas de Jeová serem coagidos a receber transfusões de sangue é um tema bastante delicado que envolve, precipuamente, a liberdade religiosa. Afinal, garante a Constituição a possibilidade de os indivíduos não apenas professarem a sua crença, mas também de agirem de acordo com ela. 
Num primeiro momento, parece que a recusa de transfusão de sangue está abarcada pela liberdade religiosa, já que tal tratamento é vedado pelos seguidores da referida religião. No entanto, pode-se pensar se teria o Estado o direito de obrigar a realização da transfusão com o intuito de proteger a saúde e até mesmo a vida de seus cidadãos. Diversos fatores devem ser considerados para que se chegue a uma conclusão.

Celso Ribeiro Bastos ${ }^{228}$, em artigo acerca do tema, entendeu que não poderiam tais pessoas ser obrigadas à prática de tal conduta, sob pena de agressão à liberdade religiosa. A partir do momento em que o Estado determinasse a ocorrência da transfusão estaria violentando de modo permanente a vida privada e a intimidade das pessoas.

Afirma o autor não haver no ordenamento nenhuma lei que proíba uma ação individual de recusar uma transfusão, nem que obrigue os médicos a desconsiderar a opção do paciente. Além do que, o suicídio, ou sua tentativa, não sofre punição pelo ordenamento brasileiro.

Mesmo que tais leis existissem seriam elas inconstitucionais, de maneira que se não caberia nem à lei determinar tal tipo de conduta, caberia ainda menos aos médicos impor tal prática a uma testemunha de Jeová. Assim, para que a transfusão fosse obrigatória, seria preciso que a busca de tratamento médico também o fosse. E, claramente, não há tal obrigatoriedade na ordem jurídica brasileira.

Aldir Soriano, ${ }^{229}$ sobre a mesma discussão, entende que havendo possibilidade de tratamento alternativo à transfusão de sangue, não haveria dúvidas de que deveria prevalecer a liberdade religiosa do paciente. Já quando a transfusão se demonstra imprescindível, surgiria uma colisão de direitos, mais especificamente entre o direito à vida e o direito à liberdade religiosa.

O problema, de acordo com o autor, não poderia ser resolvido levando-se em consideração a irrenunciabilidade dos direitos, uma vez que ambos são igualmente irrenunciáveis. Por outro lado, partindo-se do pressuposto que um dos direitos pode ser renunciado, surgem duas soluções. Prevalecendo o direito à vida, a transfusão de sangue deveria ser realizada. Por outro lado, sendo a liberdade religiosa considerada preponderante, o direito à vida seria negligenciado. Desta opinião compartilhariam as Testemunhas de Jeová que preferem a morte a submeter-se ao procedimento de transfusão de sangue.

\footnotetext{
${ }^{228}$ BASTOS, 2001, p. 493-507

${ }^{229}$ SORIANO, A., 2002, p. 119-121.
} 
O autor crê que a Constituição Federal admite a inalienabilidade do direito à vida, mas não a sua irrenunciabilidade, tanto que a autolesão e a tentativa de suicídio não são punidas. Por esse raciocínio seria permitido renunciar à vida.

Advogando pela sobreposição do direito à vida, o autor argumenta que a eutanásia é proibida no ordenamento brasileiro, o que impediria a renúncia à vida.

No que diz com a responsabilização do médico, a opinião do autor é que tendo sido seguidas as orientações do Conselho Federal de Medicina, não haveria que se falar em responsabilidade.

Outra situação é a transfusão de sangue em menores e a responsabilidade dos pais e dos médicos frente à sua negativa. Segundo o autor, não há que se falar em negligência ou qualquer outra espécie de culpa, quando os pais demandam que o médico recorra a tratamentos alternativos à transfusão. Consubstanciando tal posicionamento, cita o autor a Declaração de Helsinque, da Associação Médica Mundial, que determina o respeito às escolhas feitas pelos pais.

A jurisprudência brasileira também já se pronunciou sobre o tema, demonstrando posições divergentes acerca da possibilidade de recusa ao tratamento com transfusão de sangue. In verbis:

CAUTELAR. TRANSFUSÃO DE SANGUE. TESTEMUNHAS DE JEOVÁ. NÃO CABE AO PODER JUDICIÁRIO, NO SISTEMA JURÍDICO BRASILEIRO, AUTORIZAR OU ORDENAR TRATAMENTO MÉDICOCIRÚRGICOS E/OU HOSPITALARES, SALVO CASOS EXCEPCIONALÍSSIMOS E SALVO QUANDO ENVOLVIDOS OS INTERESSES DE MENORES. SE IMINENTE O PERIGO DE VIDA, É DIREITO E DEVER DO MÉDICO EMPREGAR TODOS OS TRATAMENTOS, INCLUSIVE CIRÚRGICOS, PARA SALVAR O PACIENTE, MESMO CONTRA A VONTADE DESTE, E DE SEUS FAMILIARES E DE QUEM QUER QUE SEJA, AINDA QUE A OPOSIÇÃO SEJA DITADA POR MOTIVOS RELIGIOSOS. IMPORTA AO MÉDICO E AO HOSPITAL DEMONSTRAR QUE UTILIZARAM A CIÊNCIA E A TÉCNICA APOIADAS EM SÉRIA LITERATURA MÉDICA, MESMO QUE HAJA DIVERGÊNCIAS QUANTO AO MELHOR TRATAMENTO. O JUDICIÁRIO NÃO SERVE PARA DIMINUIR OS RISCOS DA 
PROFISSÃO MÉDICA OU DA ATIVIDADE HOSPITALAR. SE TRANSFUSÃO DE SANGUE FOR TIDA COMO IMPRESCINDÍVEL, CONFORME SÓLIDA LITERATURA MÉDICO-CIENTÍFICA (NÃO IMPORTANDO NATURAIS DIVERGÊNCIAS), DEVE SER CONCRETIZADA, SE PARA SALVAR A VIDA DO PACIENTE, MESMO CONTRA A VONTADE DAS TESTEMUNHAS DE JEOVÁ, MAS DESDE QUE HAJA URGÊNCIA E PERIGO IMINENTE DE VIDA (ART. 146, $\S 3^{\circ}$, INC. I, DO CÓDIGO PENAL). CASO CONCRETO EM QUE NÃO SE VERIFICAVA TAL URGÊNCIA. O DIREITO À VIDA ANTECEDE O DIREITO À LIBERDADE, AQUI INCLUÍDA A LIBERDADE DE RELIGIÃO; É FALÁCIA ARGUMENTAR COM OS QUE MORREM PELA LIBERDADE POIS, AÍ SE TRATA DE CONTEXTO FÁTICO TOTALMENTE DIVERSO. NÃO CONSTA QUE MORTO POSSA SER LIVRE OU LUTAR POR SUA LIBERDADE. HÁ PRINCÍPIOS GERAIS DE ÉTICA E DE DIREITO, QUE ALIÁS NORTEIAM A CARTA DAS NAÇÕES UNIDAS, QUE PRECISAM SE SOBREPOR AS ESPECIFICIDADES CULTURAIS E RELIGIOSAS; SOB PENA DE SE HOMOLOGAREM AS MAIORES BRUTALIDADES; ENTRE ELES ESTÃO OS PRINCÍPIOS QUE RESGUARDAM OS DIREITOS FUNDAMENTAIS RELACIONADOS COM A VIDA E A DIGNIDADE HUMANAS. RELIGIÕES DEVEM PRESERVAR A VIDA E NÃO EXTERMINÁ-LA. ${ }^{230}$

$\mathrm{O}$ acórdão do TJ-RS entende que, em princípio, não deveria o Estado se envolver em questões médicas, tais como a possibilidade de transfusão de sangue. Em havendo, contudo, perigo iminente de vida ou interesses de menores, o Tribunal decide que cabem aos médicos e ao hospital empregar todos os meios disponíveis para salvar a vida do paciente, ainda que contra a sua vontade.

Posicionamento bastante discutível de que o cidadão perde sua autonomia nos momentos mais críticos de sua vida, como nos que há iminente perigo de vida. $\mathrm{O}$ respeito à liberdade e à autonomia pelo Estado deve ser irrestrita desde que não haja risco de agressão a direitos fundamentais alheios. O verdadeiro teste da democracia está, não em

${ }^{230}$ TJ-RS - Apelação Cível No 595000373, Sexta Câmara Cível, Tribunal de Justiça do RS, Relator: Sérgio Gischkow Pereira, Julgado em 28/03/1995 
proteger as atitudes amparadas pela opinião da maioria, mas em garantir que as atitudes das minorias sejam igualmente respeitadas.

Não faz sentido argumentar que a liberdade religiosa do indivíduo deve ser respeitada somente quando a transfusão de sangue pode ser substituída por outro tratamento. $\mathrm{O}$ verdadeiro respeito está em garantir que cidadãos maiores e capazes façam a escola que estiver de acordo com a sua religião, ainda que ela desagrade à maioria da sociedade.

Em sentido contrário, é possível encontrar decisão ${ }^{231}$ também do TJ-RS. Em sede de Agravo de Instrumento, o Tribunal pondera que a agravante era pessoa lúcida e que tinha plena capacidade de manifestar sua vontade de não se submeter à transfusão de sangue, que o fez no momento em que buscou atendimento médico. Tal vontade deveria ser respeitada pelo Estado uma vez que coagir pessoa a receber determinado tratamento feriria a sua dignidade e esvaziaria de sentido a sua vida, uma vez que teria sido submetida a ato contrário à sua crença religiosa.

Tratando a questão sob o aspecto criminal, interessante citar decisão do Tribunal de Justiça de São Paulo em recurso em sentido estrito ${ }^{232}$, que vislumbrou a existência de dolo eventual na ação de pais que impediram a realização de transfusão de sangue na filha menor, que a levou à morte. Entende o Tribunal que diante destes fatos deveriam os pais e o médico, da mesma religião que incentivou o ato, ser submetidos à julgamento pelo Júri.

Seguindo a mesma linha de privilegiar a realização da transfusão de sangue, o TJ-SP 233 em julgamento de agravo de instrumento tirado contra decisão liminar que permitiu a hospital que realizasse transfusão de sangue em paciente na UTI, que recusara o tratamento, entende que a Constituição Federal proteger a vida dos cidadãos como bem primeiro, inviolável e preponderante. Julga, portanto, correta a concessão da liminar.

O Tribunal de Justiça de Minas Gerais demonstra ter um posicionamento mais favorável à pretensão dos pacientes Testemunhas de Jeová. Vislumbrando um conflito entre o direito à vida e a liberdade religiosa e de crença, entende o Tribunal que o Estado não pode compelir o cidadão a submeter-se a um tratamento contrário à sua

\footnotetext{
${ }^{231}$ TJ-RS - Agravo de Instrumento No 70032799041, Décima Segunda Câmara Cível, Tribunal de Justiça do RS, Relator: Cláudio Baldino Maciel, Julgado em 06/05/2010

${ }^{232}$ TJ-SP - 9a Câmara de Direito Criminal - Recurso em Sentido Estrito 993990853540 (293764300000000) Rel. Francisco Bruno - Data do julgamento: 28/01/2010 - Data de registro: 10/02/2010.

233 TJ-SP - Segunda Câmara de Direito Privado de Férias - Agravo de Instrumento 994031132419 (3076934400) - Rel. Maia da Cunha - Data de registro: 04/11/2003.
} 
convicção religiosa. ${ }^{234} \mathrm{O}$ Tribunal considera abusiva a decisão que determina hospital a realizar procedimento recusado pelo paciente ${ }^{235}$, diferentemente do que entende o Tribunal de Justiça de São Paulo que tende a privilegiar o direito à vida.

Gerard $^{236}$ demonstra que a jurisprudência estrangeira também já se pronunciou sobre o caso. Em análise sobre decisão da Corte Suprema Austríaca, a Comissão Europeia de Direitos Humanos alegou que os pais teriam negligenciado o interesse da criança, notadamente, eles não consideraram suficientemente os riscos ligados à recusa da mãe em consentir em uma transfusão de sangue. Para a Comissão, a legislação austríaca que permite a suspensão do exercício da autoridade parental em caso de urgência diminui o risco de tal tipo de conduta. A Comissão se contenta em salientar que a Corte Suprema Austríaca apreciou os fatos relativos ao interesse das crianças de maneira diversa das jurisdições inferiores, e que, em sua fundamentação, se apoiou em laudos psicológicos, reforçando a impressão de uma distinção ditada essencialmente por considerações religiosas.

Na Espanha, Lopez Castillo ${ }^{237}$ cita decisão do Tribunal Constitucional que manteve a condenação de pais, por conduta omissiva, ao negar ao filho menor a autorização para que fosse feita a transfusão de sangue. A Corte entende que a liberdade religiosa dos pais não teria o condão de impedir a tutela de um bem juridicamente protegido pelo ordenamento, ainda que o filho compartilhasse do mesmo credo. O poder familiar demandaria a obrigação de tutelar pelo direito à vida e à saúde do filho, de modo que não caberia a invocação da liberdade religiosa.

Já se discutiu a eventual possibilidade de ressarcimento dos gastos médicos às Testemunhas de Jeová que acabaram tendo que se submeter a tratamento sem transfusão de sangue em clínicas particulares, uma vez que o tratamento não seria oferecido na rede pública de saúde. O Superior Tribunal Constitucional já proferiu decisão negando o ressarcimento.

O mesmo autor cita decisão do Tribunal Constitucional no sentido de condenar por homicídio uma Testemunha de Jeová que teria precipitado a morte de pessoa do mesmo credo ao retirar o cateter que realizava a transfusão de sangue.

\footnotetext{
${ }^{234}$ TJ-MG - Apelação 1.0701.07.191519-6/001(1) - Rel. Des. Alberto Vilas Boas - Julgado em 14/08/2007.

${ }^{235}$ TJ-MG - Mandado de Segurança 4776822-06.2008.8.13.0000 - Rel. Des. Heloisa Combat - Julgado em $16 / 12 / 2008$

${ }^{236}$ GONZALEZ, 1997, p. 132.

${ }^{237}$ LÓPEZ CASTILLO, 2001, p. 23-5.
} 
Álvaro Villaça ${ }^{238}$ trata da possibilidade de recusa de transfusão de sangue por Testemunhas de Jeová. O autor começa afirmando a preocupação das Testemunhas de Jeová em buscar tratamento médico, uma vez que acreditam ser a saúde uma dádiva de Deus.

Para os que professam esta crença, a recusa da transfusão de sangue é total e envolve também os "seus quatro componentes primários, ou seja, glóbulos vermelhos, glóbulos brancos, plaquetas e plasma. Ao agirem dessa forma, obedecem a diretriz bíblica encontrada no livro de Atos dos Apóstolos, capítulo 15, versículos 28 e 29."239

As Testemunhas entendem que cabe a cada pessoa determinar se irá aceitar tratamentos com frações menores de sangue ou mesmo a realização de exames em que seja utilizado o próprio sangue.

$\mathrm{O}$ autor relembra que o tratamento com transfusão de sangue envolve riscos de contaminação e incompatibilidade que devem ser considerados. Os riscos inerentes à transfusão de sangue são reconhecidos pelos Conselhos de Medicina, por agências governamentais. A existência de tais riscos legitimaria, portanto, a recusa da transfusão, principalmente, quando há outros tratamentos alternativos.

A recusa pelas Testemunhas de Jeová não significa rejeição a todos os tratamentos médicos, muito menos o exercício do direito de morrer. Assim, quando um paciente Testemunha de Jeová procura um hospital para se tratar e opta não receber a transfusão de sangue, ele está realizando uma escolha legítima sobre o tratamento que pretende receber, sob justificativa da crença religiosa.

Não haveria, assim, uma colisão entre o direito à vida e à liberdade religiosa, mas sim o pleno exercício de ambos. Neste diapasão, o autor cita duas decisões [TJMT - Rec-AI 22395/2006 - Cuiabá, 5a Câmara Cível, Rel. Des. Leondias Duarte Monteiro, j. em 31/05/2006 e Agravo n. 191.519-6/001, in www.tjmg.gov.br, julgado em 14/08/2007], em que não houve a preocupação em determinar qual direito deveria prevalecer. Os acórdãos foram no sentido de privilegiar a dignidade da pessoa humana, considerando o direito à vida e a liberdade de escolha dos pacientes.

\footnotetext{
${ }^{238}$ VILLACA, Álvaro Villaça. Autonomia do paciente e direito de escolha de tratamento médico sem transfusão de sangue mediante os atuais preceitos civis e constitucionais brasileiros. Parecer. São Paulo: 2010.

${ }^{239}$ VILLACA, Op. cit., p. 4
} 
O direito de escolha de tratamentos médicos poderia ser realizado por qualquer pessoa independentemente de crenças religiosas. Contudo, quando a escolha fosse baseada em motivos religiosos, a opção ganharia especial relevância.

Relembra o autor o art. 15 do Código Civil, ao prescrever que ninguém pode ser constrangido a submeter-se, com risco da vida, a tratamento médico ou à intervenção cirúrgica. Tal dispositivo seria, assim, uma celebração da autonomia da vontade, ao respeitar a escolha do paciente a tratamentos médicos, principalmente se ele apresentar riscos à saúde.

O desrespeito à escolha realizada pelo paciente pode gerar, inclusive, responsabilidade civil do médico. Inerente a esta realidade é o estado em que se encontra o paciente para dar o seu consentimento. Há quem entenda que o médico pode ignorar a vontade do paciente em caso de iminente perigo de vida e de inconsciência.

Salienta o autor que os direitos de personalidade são inatos, não dependendo de quaisquer condições externas, já que são projeções da dignidade da pessoa humana. Considerando tal característica a doença com que esteja acometido o paciente em nada influencia a sua autonomia de vontade. A situação emergencial não altera a escolha feita pelo paciente, que deve respeitada em quaisquer situações.

O Estatuto do Idoso (Lei 10.741/03) determina, em seu art. 17, que o idoso que esteja nas suas faculdades mentais tem o direito assegurado de escolher o próprio tratamento médico.

Todavia, emenda o parágrafo único desse mesmo artigo, que, não estando o idoso em condições de exercer essa opção, ou seja, não estando ele com o discernimento dos fatos de sua vida, o consentimento será manifestado: I) pelo curador, quando o idoso for interditado; II) pelos familiares, quando o idoso não tiver curador ou este não puder ser contatado e tempo hábil; III) pelo medico, quando ocorrer iminente risco de vida e não houver tempo para consulta a curador ou familiar; IV) pelo próprio médico, quando não houver curador ou familiar conhecido, caso em que devera comunicar o fato ao Ministério Público. ${ }^{240}$

$\mathrm{O}$ autor sugere que o idoso seja cercado de mensagens escritas e avisos destinados a médicos em relação a suas escolhas. Feita a escolha com antecedência o médico deverá respeitá-la, independentemente de a situação ser emergencial ou não. Não havendo escolha pré-determinada, o médico somente terá poder de decisão caso não seja possível contatar a família.

${ }^{240}$ VILLACA, 2010, p. 26. 
A Lei de Transplantes (Lei. 9.434/97) também se preocupa com a questão do consentimento, determinando que o transplante somente será realizado quando houver anuência do receptor, sendo-lhe informados todos os riscos inerentes ao procedimento. $\mathrm{O} \S$ $1^{\mathrm{o}}$ do art. 10 estabelece que não sendo possível obter a declaração de vontade do receptor, ela o será de um de seus pais ou representantes legais. E a impossibilidade de obter o consentimento poderá advir tanto da menoridade quanto por qualquer outra situação que retire a possibilidade de discernimento do paciente.

Na Resolução 1.021/80 do Conselho Federal de Medicina, há orientação para os médicos de somente respeitar a escolha do paciente se não houver perigo de morte. $\mathrm{O}$ autor ressalta que a Resolução do CFM é anterior à Constituição Federal e ao Código Civil, além de não tratar os pacientes Testemunhas de Jeová com razoabilidade, deixando de considerar, inclusive, a possibilidade de tratamentos alternativos à transfusão de sangue.

O próprio CFM já manifestou opinião diferente da inscrita na Resolução ao absolver médica que não realizou transfusão de sangue em respeito à vontade do paciente numa situação emergencial.

A Resolução que aprovou o Código de Ética Médica em 2009 tem como uma de seus fundamentos a melhoria do relacionamento entre médico e paciente e a garantia da maior autonomia da vontade. In verbis:

XXI- No processo de tomada de decisões profissionais, de acordo com seus ditames de consciência e as precisões legais, o médico aceitará as escolhas de seus pacientes, relativas aos procedimentos diagnósticos e terapêuticos por eles expressos, desde que adequadas ao caso e cientificamente reconhecidas.

O autor cita ainda o art. 22 do CEM que "determina ser vedado ao médico deixar de obter consentimento do paciente ou de seu representante legal após esclarecê-lo sobre o procedimento a ser realizado, salvo em caso de iminente risco de morte. "241

De acordo com o entendimento de Álvaro Villaça, a leitura apressada do dispositivo levaria a uma conclusão equivocada de que a autonomia do paciente não precisaria ser considerada em caso de iminente perigo de vida. Para o autor, a interpretação deverá ser para determinar que em algumas situações emergenciais não seria possível esclarecer o paciente sobre o procedimento e muito menos obter o seu consentimento. Somente nestes casos em que o paciente encontrar-se-ia inconsciente seria possível pensar

${ }^{241}$ VILLACA, 2010, p. 30. 
num consentimento presumido. Haveria, assim, uma diferença entre deixar de obter o consentimento e agir contra o consentimento.

$\mathrm{O}$ art. 31 do CEM entende que é vedado ao médico "desrespeitar o direito do paciente ou de seu representante legal de decidir livremente sobre a execução de práticas diagnósticas ou terapêuticas, salvo em caso de iminente risco de morte." O autor afirma que tal dispositivo não deveria ser considerado, uma vez que contraria toda a legislação brasileira e, inclusive, a concepção do CEM.

Para que não haja dúvidas quanto ao consentimento de Testemunha de Jeová, o autor recomenda que o paciente tome medidas preventivas e fique munido de documentos de antecipação de vontade juridicamente válidos. O instrumento válido para a declaração de vontade leva a denominação de "Instruções de Procuração para Tratamento de Saúde"

Ressalta que tais documentos suprem os requisitos de validade do negócio jurídico (agente capaz, objeto lícito, possível e determinado ou determinável e forma prescrita ou não defesa em lei).

Uma das repercussões envolvendo a possibilidade de transfusão de sangue e Testemunhas de Jeová é a possível configuração do delito de omissão de socorro, nos termos do art. 135 do Código Penal. O autor cita diversos penalistas que entendem ser o dolo elemento indispensável à caracterização do crime, de modo que o agente deva agir consciente e deliberadamente com a intenção de não prestar assistência. Assim, o médico que conduz o tratamento de acordo com as determinações do paciente não pode ser acusado de dolo em omissão de socorro.

Pelo contrário, se o médico constranger o paciente a realizar uma transfusão de sangue contra a sua vontade incorrerá em crime de constrangimento ilegal (art. 146, $\mathrm{CP})$.

O fundamento do crime de constrangimento ilegal está no art. $5^{\circ}$, II da $\mathrm{CF} / 88$ de que ninguém será obrigado a fazer ou deixar de fazer alguma coisa senão em virtude de lei. Não havendo nenhuma lei que obrigue a submeter-se a determinado tratamento médico, o paciente não pode a isso ser compelido.

O grande debate acerca da possibilidade de realização de transfusão de sangue é quando o paciente é menor. Nestes casos, surge o argumento da existência de uma colisão entre direitos fundamentais, ou seja, entre o direito à liberdade religiosa dos pais e o direito à vida do filho menor. Afirma o autor que a alegada colisão, na realidade, 
não existe, uma vez que os pais Testemunhas de Jeová não estão negando tratamento aos filhos, mas apenas realizando uma escolha de tratamento, o que estaria incluído no poder familiar.

Os pais, assim, teriam a obrigação de garantir a saúde dos seus filhos, mas igualmente teriam o direito de escolher o procedimento médico que seria empregado em seu filho. Destarte, a escolha de tratamento não configuraria abandono ou omissão, nos termos do art. 98, II do ECA. O tratamento sem transfusão não colocaria, na visão do parecerista, em risco a vida da criança.

Conclui o autor que "[...] intervir no poder familiar dos pais e, sem o seu consentimento, administrar tratamento médico de risco, como a terapia transfusional, desconsiderando as alternativas médicas que evitam a utilização de hemocomponentes, implicará assumir as consequências pelos resultados advindos."242

Fala o autor também que o menor de idade enquanto ser humano tem todos os direitos inerentes a ele, o que envolve o exercício da autonomia enquanto manifestação da sua dignidade.

Para esta questão, de exercício da autonomia, ganha importância a teoria do menor amadurecido, que pretende privilegiar a autonomia do menor, independentemente da sua idade. Tal teoria revela uma exceção à ideia de que o menor tem presunção de incapacidade. No campo da saúde, o menor amadurecido é aquele que tem capacidade para tomar as próprias decisões, entendendo as consequências dos tratamentos oferecidos, exercendo assim o chamado consentimento informado.

A Convenção das Nações Unidas sobre Direitos da Criança, inclusive, prevê em seu art. 12 que:

Os Estados Partes assegurarão à criança que estiver capacitada a formular seus próprios juízos o direito de expressar suas opiniões livremente sobre todos os assuntos relacionados com a criança, levando-se devidamente em consideração essas opiniões, em função da idade e da maturidade. ${ }^{243}$

Essa teoria do menor amadurecido encontra respaldo em diversos países europeus, mas não há qualquer construção doutrinária no Brasil. Alguns dispositivos legais consideram a vontade do menor, a exemplo do art. 1621, CC que impõe a necessidade de oitiva do maior de 12 anos em caso de adoção, do art. 1740, CC, que trata do tutor e do art.

${ }^{242}$ VILLACA, 2010, p. 44.

${ }^{243}$ VILLACA, Op. cit., p. 45. 
$28, \S 1^{\circ}$ do ECA que trata também da oitiva do menor na adoção sem referir-se a uma idade específica.

Dessa maneira, o menor com capacidade de discernimento tem legitimidade para prestar o consentimento informado. Não deve haver, contudo, uma idade mínima que para o menor dê o seu consentimento, uma vez que se trata de uma capacidade natural e não civil.

Nelso Nery Junior ${ }^{244}$ ao receber consulta da Associação de Testemunhas de Jeová também emitiu parecer que aborda os pontos mais importantes da matéria.

Tratando especificamente da atitude do Estado frente à religião expõe o autor a ideia de que o Estado deveria basear-se em dois preceitos, o da liberdade religiosa e o da igualdade. O Estado não poderia, assim, impor condutas aos cidadãos que ferissem a sua convicção religiosa, nem por meio de lei, nem por meio de decisão judicial. Com base nesta premissa, qualquer tratamento que envolvesse transfusão de sangue em Testemunha de Jeová deveria necessariamente depender de seu consentimento.

É bastante comum encontrar decisões judiciais que determinem a Testemunhas de Jeová a realização de tratamentos com transfusão de sangue, sob o argumento de uma colisão de direitos entre a liberdade religiosa e o direito à vida. Segundo o autor, a colisão de direitos fundamentais seria apenas aparente e não importaria verdadeiro conflito.

A falsidade da colisão reside exatamente no fato de que a verdadeira colisão ocorre quando o exercício de um direito fundamental obsta o exercício de direito fundamental de outrem, o que obviamente não ocorre no caso. A recusa à transfusão de sangue por Testemunha de Jeová não fere o direito fundamental de mais ninguém. Haveria, apenas, uma colisão de direitos caso a recusa de tratamento envolvesse uma doença epidêmica que pudesse ameaçar a saúde pública.

Tanto é assim que a Portaria 1820/2009 do Ministério da Saúde garante o direito de escolha de tratamento médico, com exceção dos casos que causem risco à saúde pública, em que o consentimento poderá ser revogado sem imputação de qualquer sanção moral, financeira ou legal.

Não se pode pensar também na existência de uma colisão de direitos fundamentais em sentido amplo, ou seja, entre bens coletivos. Poder-se-ia pensar que a recusa de transfusão de sangue feriria a tutela da sociedade com a vida. Tal assertiva não

${ }^{244}$ NERY JUNIOR, Nelson. Escolha esclarecida de tratamento medico por pacientes Testemunhas de Jeová como exercício harmônico de direitos fundamentais. Parecer. São Paulo, 2009. 
seria verdadeira, uma vez que os pacientes Testemunhas de Jeová não estão recusando qualquer tipo de tratamento, mas apenas um em específico.

Para o autor, decisões judiciais que imponham o tratamento com transfusão de sangue são insustentáveis por falta de argumentação jurídica e adequação social. Ademais, a obrigatoriedade de uma conduta deve estar de acordo com o princípio da legalidade, que impõe a necessidade de lei.

Com base nestes argumentos, sustenta-se o absurdo da Portaria do Secretário de Saúde do DF que autoriza a realização de tratamento com transfusão de sangue em pacientes com iminente perigo de vida, mesmo contra a vontade destes. Em sentido contrário e consentâneo com a CF/88, está a Portaria 1820/09 ${ }^{245}$ que garante o direito à prática do consentimento informado.

A eventual imposição de tratamento a Testemunhas de Jeová representaria a chamada colonização do mundo da vida, que ocorreria quando o "Estado invade a esfera de liberdade individual do cidadão, destruindo-a."246

Além do que, o direito à recusa da transfusão de sangue está amparado não só pela dignidade humana e pela liberdade religiosa, mas também pelo direito à privacidade e à intimidade.

A obrigatoriedade de realização de determinado tratamento feriria, de acordo com o autor, o próprio Estado Democrático de Direito, uma vez que impediria a existência do diferente e a aceitação da desigualdade seria elemento essencial de tal Estado.

Estabelecida a possibilidade de recusa da transfusão de sangue, parte o autor para os aspectos inerentes à forma de como se dá tal recusa, que é o consentimento informado.

Cabe, portanto, acrescer que, na linguagem técnica do direito, o consentimento informado é a capacidade de decisão do paciente quanto ao tratamento que receberá, decisão esta que só poderá ser tomada após detalhado esclarecimento médico e fornecimento de todas as informações relativas ao mesmo. ${ }^{247}$

\footnotetext{
${ }^{245}$ Art. 5o Toda pessoa deve ter seus valores, cultura e direitos respeitados na relação com os serviços de saúde, garantindo-lhe:

V - o consentimento livre, voluntário e esclarecido, a quaisquer procedimentos diagnósticos, preventivos ou terapêuticos, salvo nos casos que acarretem risco à saúde pública, considerando que o consentimento anteriormente dado poderá ser revogado a qualquer instante, por decisão livre e esclarecida, sem que sejam imputadas à pessoa sanções morais, financeiras ou legais;

${ }^{246}$ NERY JUNIOR, 2009, p. 22.

${ }^{247}$ NERY JUNIOR, Op. cit., p. 25
} 
O consentimento informado seria, portanto, uma forma imprescindível de garantir o pleno exercício da liberdade. Citando Antonio Rovira ${ }^{248}$, o autor trata da autonomia pessoal como "a possibilidade e a necessidade de exercer a liberdade com suas consequências, sejam elas boas ou más, num universo de possibilidades." Decorre desta afirmação, a capacidade de o paciente exercer o consentimento informado, independentemente do seu estado de saúde.

Fundamentando o direito de recusa na liberdade de autodeterminação, relembra Nelson Nery que tal liberdade encontra lastro em todo o direito privado, a exemplo do Código Civil (art. 15), da Lei dos Transplantes e do Estatuto do Idoso.

Questiona o autor se o Código Civil trata da impossibilidade de constranger um paciente a submeter-se a tratamento, se o Estatuto do Idoso garante a opção pelo tratamento que parecer mais favorável, se a Lei de Transplantes exige o consentimento do receptor para a realização do transplante, qual seria a razão para impedir que uma Testemunha de Jeová recuse a transfusão de sangue. Parece que a única razão para tal concepção seria a intolerância religiosa e sendo esta a única razão, seria uma clara hipótese de discriminação religiosa.

Relembra o autor que as Testemunhas de Jeová não estão tentando o suicídio, já que não recusam a ideia da cura pelo tratamento, mas apenas a cura sem transfusão de sangue. Neste sentido, se o médico respeita a vontade do paciente não poderá jamais servir para que ele responda por omissão de socorro.

No mesmo sentido, entende Nelson Nery que não pode configurar omissão de socorro quando os pais negam o tratamento com transfusão de sangue para o filho menor, uma vez que falta o próprio tipo objetivo, que é a existência de criança abandonada ou extraviada

Ainda tratando de questões penais, o médico não responde por constrangimento ilegal (art. 146, $\S 3^{\circ}$, I) quando realiza intervenção cirúrgica sem o consentimento do paciente. Tal excludente não permite, porém, que seja feito qualquer procedimento contra a vontade do paciente, mas tão-somente para os casos em que não houve prévia manifestação de vontade do paciente. Tanto é assim que se o médico praticar ato contrário ao consentimento do paciente cometerá crime de constrangimento ilegal.

\footnotetext{
${ }^{248}$ ROVIRA, Antonio. Autonomia personal y tratamento medico - una aproximación constitucional al consentimiento informado. Pamplona: Aranzadi, 2007, p. 49 apud NERY JUNIOR, 2009, p. 27.
} 
O autor do parecer preocupa-se em elencar os princípios do tratamento sem transfusão de sangue, de modo a demonstrar a sua difusão pelo mundo e também a real possibilidade de implantação de tal tipo de tratamento. Da mesma forma que Villaça, Nelson Nery ressalta que a transfusão de sangue é um procedimento que gera riscos para o paciente, o que legitimaria a sua recusa.

Alonga-se autor em fazer comentários sobre os diversos diplomas médicos referentes sobre o tema. Acerca do já citado art. 22 do Código de Ética Médica. ${ }^{249} \mathrm{~A}$ interpretação dada pelo autor segue a mesma linha da aqui já exposta, em que o médico pode tomar a decisão que lhe parecer melhor quando o paciente não manifestar qualquer tipo de objeção. Aqui há necessidade de aplicação de interpretação conforme à Constituição para que não se chegue a uma interpretação destoante de todo o ordenamento jurídico.

Mais preocupante, segundo o autor, é a Resolução 1021/80 do CFM, que possibilita a transfusão de sangue em caso de iminente perigo de vida. Tal dispositivo feriria frontalmente a dignidade humana (art. $1^{\circ}$, III da CF), a liberdade (art. $5^{\circ}$, caput) e a liberdade de crença (art. 5, VI). Além disso, a Resolução contraria a Lei 8.080/90, em seu art. $7^{\circ}$, que impõe a autonomia pessoal como um dos princípios das ações e serviços públicos de saúde.

A Portaria $1.820 / 09^{250}$ do Ministério da Saúde estabeleceu os parâmetros para o exercício do consentimento informado. Com a edição de tal Portaria poder-se-ia, considerar revogada a Resolução 1.021/80 do CFM, já que suas disposições são contrárias.

$\mathrm{O}$ autor demonstra, ainda, que a jurisprudência tem adotado a ideia do consentimento informado, permitindo a recusa ao tratamento com transfusão de sangue por Testemunhas de Jeová. Tal é o posicionamento, inclusive, prevalecente nas decisões de

${ }^{249}$ Art. 22. Deixar de obter consentimento do paciente ou de seu representante legal após esclarecê-lo sobre o procedimento a ser realizado, salvo em caso de risco iminente de morte.

${ }^{250}$ Art. $3^{\circ}-[\ldots]$

II - informações sobre o seu estado de saúde, de maneira clara, objetiva, respeitosa, compreensível quanto a:

a) possíveis diagnósticos;

b) diagnósticos confirmados;

c) tipos, justificativas e riscos dos exames solicitados;

d) resultados dos exames realizados;

e) objetivos, riscos e benefícios de procedimentos diagnósticos, cirúrgicos, preventivos ou de tratamento;

Art. $5^{\circ}$ Toda pessoa deve ter seus valores, cultura e direitos respeitados na relação com os serviços de saúde, garantindo-lhe:

V - o consentimento livre, voluntário e esclarecido, a quaisquer procedimentos diagnósticos, preventivos ou terapêuticos, salvo nos casos que acarretem risco à saúde pública, considerando que o consentimento anteriormente dado poderá ser revogado a qualquer instante, por decisão livre e esclarecida, sem que sejam imputadas à pessoa sanções morais, financeiras ou legais; 
Tribunais estrangeiros, tais como, EUA, Argentina, Panamá, Espanha. No mesmo sentido, cita o autor diversas decisões estrangeiras favoráveis à validade de documento para declaração formal de recusa a tratamento com transfusão de sangue.

Referindo-se especificamente ao consentimento informado, Nelson Nery classifica o consentimento informado como ato jurídico stricto sensu, de modo a não haver forma prescrita em lei. A sua prática poderia, então, dar-se de forma livre, em observância ao art. 109, CC. A despeito disso, o médico pode tomar precauções para a prova da validade do ato, requerendo, por exemplo, a assinatura de termo ou ainda a presença de testemunhas.

Para que o ato tenha validade, basta manifestação de vontade seja ela escrita ou verbal. Para tanto, basta que a pessoa tenha capacidade para consentir. E tal capacidade difere-se da capacidade negocial, exigindo-se apenas que o agente tenha capacidade de exprimir uma decisão racional, podendo ter capacidade para consentir o absoluta e o relativamente incapaz.

Para exprimir a sua vontade, Testemunhas de Jeová podem se valer de testamentos vitais que seriam "documentos nos quais o declarante simplesmente declara, sem constituir ou nomear procurador, preventivamente, quais atuações médicas lhe são desejadas ou indesejadas, caso ele não esteja, no momento da intervenção médica, em condições de manifestar a sua vontade."251

Outro documento válido seria a procuração de cuidados de saúde, em que o paciente além de especificar as instruções no caso de intercorrências médicas, também nomeia procurador para transmitir ao médico a sua vontade.

Tais documentos têm utilidade apenas nas situações em que o próprio paciente não está em condições de manifestar a sua vontade, já que sendo possível sua expressão ela deve ser considerada. A revogação tanto do testamento quanto da procuração pode ocorrer a qualquer tempo, sem exigência de forma específica.

Os documentos de declaração de vontade têm um duplo efeito, vinculante e eximidor. Vinculante, pois obriga os profissionais da saúde a respeitar o seu conteúdo. Da mesma forma que vincula, exime os mesmos profissionais de eventual responsabilidade. A recusa de tratamento é um risco assumido pelo paciente que envolve inclusive se desta recusa sobrevier morte.

Ademais, ressalta o autor que a recusa de tratamento com transfusão de

${ }^{251}$ NERY JUNIOR, 2009, p. 46. 
sangue não autoriza o hospital a abandonar o paciente, negando-lhe atendimento.

Determinadas as bases da recusa ao tratamento com transfusão de sangue, o autor passa a tratar da inconstitucionalidade das decisões liminares que obrigam Testemunhas de Jeová a se submeter à transfusão.

Do ponto de vista processual, coagir uma pessoa a um tratamento médico não pode ser objeto de uma liminar, uma vez que tal medida teria caráter satisfativo. Providências liminares irreversíveis não podem ser concedidas em processos cautelares.

Independentemente do processo empregado, tal decisão não seria possível por falta de fundamento jurídico, em afronta ao art. 93, IX da CF/88. Não há fundamentação nem constitucional nem legal para a decisão que obriga uma pessoa a submeter-se a um ato que fere a sua dignidade, intimidade e liberdade, o que faria uma eventual decisão neste sentido atentatória ao princípio da legalidade (art. $5^{\circ}$, II).

Relembra o autor a Lei de Transplantes que exige o consentimento do receptor para a doação de órgãos e questiona qual seria o sentido de exigir a aceitação no transplante e ignorar a vontade do paciente na transfusão de sangue.

Impor a transfusão de sangue fere, segundo o autor, diretamente a escusa de consciência (art. $\left.5^{\circ}, \mathrm{VIII}\right)$, garantida pela Constituição ao prever que ninguém poderá ser privado de direitos em razão de motivos religiosos.

Tal tipo de decisão é inconstitucional por não ter nenhum fundamento na Carta Magna, além de em caso de ter sido concedida inaudita altera pars, a sua inconstitucionalidade será reforçada pela ofensa aos princípios do contraditório e da ampla defesa.

Continua salientando o autor que o paciente Testemunha de Jeová não deseja a morte, mas apenas quer ser tratado sem a realização de transfusão de sangue. E cabe ao Estado garantir o tratamento alternativo, por determinação do art. 196 da CF, que garante a saúde como um direito de todos.

Pergunta-se Nelson Nery qual seria o instrumento jurídico adequado para que a pessoa se resguarde contra uma possível decisão liminar que envolva a obrigação da transfusão de sangue. Conclui o autor que a ação mais adequada seria a de habeas corpus, também na modalidade preventiva, uma vez que não se demonstra rara uma ofensa à liberdade de locomoção da pessoa.

Tratando especificamente da possibilidade de transfusão de sangue em 
menor, cujos pais sejam Testemunhas de Jeová, Antônio Chaves ${ }^{252}$ toma como base decisão do Tribunal de Justiça do Paraná, que em 03/06/92, autorizou a realização de cirurgia com transfusão para um bebê de seis meses. A cirurgia não ocorreu a tempo e a criança veio a falecer.

O autor refere-se a uma carta da Sociedade Torre de Vigia de Bíblias e Tratados, que expõe a viabilidade da realização de cirurgias sem transfusão de sangue. Com base nesta informação, o autor questiona se a utilização de tratamentos alternativos, sem sangue, não seriam suficientes para salvar a vida de pacientes. Em vez de empregar logo o tratamento alternativo, ter-se-ia perdido tempo discutindo judicialmente a possibilidade de transfusão de sangue, deixando o bebê sem tratamento.

Analisando o assunto sob a perspectiva da responsabilidade médica, há quem $^{253}$ entenda que em casos não emergenciais não se justifica um tratamento coercitivo, sendo obrigatório o consentimento do paciente ou familiares. Já em situações de iminente perigo de morte, vislumbra-se a possibilidade de tratamento compulsório.

Note-se que o paciente, ainda que numa situação emergencial, o paciente não perde sua autonomia, de modo que um tratamento contra o seu consentimento terá sempre um caráter ofensivo e ultrajante.

Analisadas as posições tanto doutrinárias quanto jurisprudenciais, a questão referente às Testemunhas de Jeová não parece assim tão intricada quando a decisão de recusa de tratamento parte de pessoas maiores e capazes de tomar uma decisão racional.

A Constituição Federal é bem clara em garantir a plenitude da liberdade religiosa, em suas diversas facetas. A garantia da liberdade de consciência, como já dito aqui, não envolve apenas a possibilidade de acreditar no que a pessoa desejar, mas também em agir de acordo com a sua crença. Caso a possibilidade de manifestação da crença não fosse garantida pela Constituição, a liberdade religiosa restaria inócua, ao impedir que a pessoa vivesse de acordo com os preceitos em que acredita.

Neste diapasão, não há qualquer fundamentação constitucional que autorize o Estado a impedir que seus cidadãos ajam em consonância com a sua crença. Pelo contrário, tal atitude estatal é vedada constitucionalmente, pelos dispositivos que

\footnotetext{
${ }^{252}$ CHAVES, Antônio. A ordem religiosa "testemunhas de Jeová" não admite trnsfusões de sangue. Como ficam as operações com crianças em perigo de vida? Revista Trimestral de Jurisprudência dos Estados, ano 20, v. 147, São Paulo, abril, 1996.

${ }^{253}$ MATTOS, Jadir de; STUMER, Kátia Rejane; COSTA, Joselaine da. Responsabilidade penal do médico nos casos de transfusão de sangue, em menor de idade em, iminente risco de vida, cujos pais são adeptos da seita Testemunhas de Jeová. Revista de Direito Sanitário. São Paulo. v.6, n.1/3, 2005, p.132-50.
} 
determinam a laicidade do Estado.

O cerne de um Estado Democrático está em permitir quaisquer tipos de manifestações de vontade, desde que não sejam contrárias aos fundamentos do Estado. Não cabe, portanto, ao Estado realizar juízo de valor acerca das atitudes de seus cidadãos, desde que elas sejam lícitas. Ainda que à maioria das autoridades estatais pareça absurda a recusa de transfusão de sangue como tratamento médico, não lhes é deferida a possibilidade de impor suas próprias convicções, sob pena de agressão aos próprios princípios fundamentais do Estado Democrático de Direito.

As decisões judiciais que determinam a realização de transfusões de sangue em Testemunhas de Jeová revelam uma opinião religiosa por parte do Estado. Aqui, diferentemente do que ocorre na questão dos símbolos religiosos, não se identifica a predileção por uma religião em particular, mas sim um repúdio a uma religião em específico.

Ainda que se entenda que o Estado brasileiro deve ser considerado como um Estado religioso tolerante, as decisões que obrigam a transfusão de sangue em Testemunhas de Jeová não parecem aceitáveis juridicamente. A fixação de símbolos religiosos em prédios públicos pode demonstrar uma opinião religiosa do Estado, mas sua permanência não tem o condão de obstaculizar a livre manifestação de crença dos cidadãos. O Estado ao obrigar uma Testemunha de Jeová receba uma transfusão de sangue impede de maneira peremptória a crença do indivíduo, além de aniquilar o seu direito à liberdade religiosa.

Para uma Testemunha de Jeová que faça uma transfusão de sangue sua vida perde sentido, pois comete ato inadmissível para a sua crença. Já os símbolos religiosos não impedem que os indivíduos que ele se defrontem sigam professando a religião em que acreditam.

Lembre-se da teoria sobre a relatividade dos direitos fundamentais. A restrição de um direito fundamental somente é aceita constitucionalmente, se para fazer valer direito fundamental alheio que com ele conflite. Ora, no caso da transfusão de sangue não há motivo constitucional que autorize o Estado a obrigar a realização de transfusão de sangue. A Testemunha de Jeová que se recusa a receber transfusão de sangue não ameaça direito fundamental de outrem. Não há, portanto, motivo para a sua restrição, ou no caso, seu aniquilamento.

Não há nenhum verdadeiro conflito que permita a intromissão estatal. Ao 
que parece o Estado, ao desrespeitar a decisão de uma Testemunha de Jeová toma partido de uma opinião não apenas religiosa, mas sim intolerante. Um Estado religioso para que seja democrático deve pregar a tolerância religiosa, permitindo que seus cidadãos ajam de acordo com sua crença, ainda que ela seja baseada em religião minoritária.

Obrigar uma Testemunha de Jeová a realizar uma transfusão de sangue contra a sua vontade é atitude puramente intolerante do Estado, que fere de morte não só a laicidade estatal, mas principalmente a garantia à liberdade religiosa.

Apesar de não poder se falar em colisão de direitos fundamentais da mesma pessoa, ou seja, entre a liberdade religiosa e o direito à vida de Testemunha de Jeová, o mesmo, contudo, não vale quando trata-se de escolha a ser feita em nome de menor de idade. Aqui sim a intromissão do Estado seria aceitável, afinal vislumbra-se uma colisão entre o interesse dos pais e o direito à vida do menor. Caberia, ao Estado, tutelar os interesses do menor.

Costuma a doutrina neste ponto recorrer à teoria do menor amadurecido. Ainda que sem capacidade civil, tendo condições de opinar, parece razoável que a opinião do menor seja considerada judicialmente. Ela, no entanto, não deve ser tida como definitiva. Todo o contexto fático deverá ser analisado pelo juiz.

A diferença, aqui, é que o Estado não terá a obrigação de tutelar a convicção religiosa do menor, caso ela seja considerada inexistente. Poderá, assim, intervir, determinando a realização da transfusão de sangue, para privilegiar o direito à vida em detrimento de uma eventual crença religiosa.

\section{III.6- Ensino religioso}

Estabelece o parágrafo $1^{\circ}$ do art. 210 da Constituição que "o ensino religioso, de matrícula facultativa, constituirá disciplina dos horários básicos normais das escolas públicas de ensino fundamental", ${ }^{254}$ A existência de tal previsão constitucional

\footnotetext{
${ }^{254}$ Existe uma discussão na doutrina para saber se essa norma constitucional tem aplicabilidade imediata ou não. Anna Cândida da Cunha Ferraz (O ensino religioso nas escolas públicas: exegese do par. $1^{\circ}$ do art. 210 da CF. Cadernos de Direito Constitucional e Ciência Política, São Paulo, v. 5, n. 20) entende que tal dispositivo apresenta dois conteúdos distintos. O primeiro, que é impositivo, determina que no currículo mínimo do ensino fundamental deverá contar o ensino religioso. Quanto a esta determinação, a norma seria auto-exequível. Por outro lado, acredita que a norma não tem aplicabilidade imediata, pois há necessidade de que uma lei seja editada para regulamentar as condições em que o ensino deverá ser ministrado. Em outro sentido, posiciona-se Ives Gandra (Educação religiosa nas escolas públicas - inteligência do art. 210 da Constituição Federal - opinião legal. Revista de Direito Civil, São Paulo, v. 20, n. 75, p. 115-123.), ao afirmar que a norma tem eficácia plena, pois o constituinte não condicionou a sua aplicabilidade ao surgimento de uma lei. Não seria a norma, portanto, programática. Tanto que, de acordo com o autor, seria caso de responsabilidade do Estado se o ensino religioso não for implantado.
} 
gera alguns questionamentos acerca da compatibilidade do dispositivo com o Estado laico e também com a garantia da liberdade religiosa. Surgem, então, algumas questões, qual o tipo de ensino deve ser oferecido? confessional? de caráter histórico? de quais religiões?

Alexandre de Mores $^{255}$ ressalta que o ensino religioso deve ser compatibilizado com as demais liberdades públicas, como a liberdade de culto e a laicidade do Estado.

Dessa forma, destaca-se uma dupla garantia constitucional. Primeiramente, mão se poderá instituir nas escolas públicas o ensino religioso de uma única religião, nem tampouco pretender-se doutrinar os alunos a essa ou aquela fé. A norma constitucional pretende, implicitamente, que o ensino religioso deverá constituir-se de regras gerais sobre a religião e princípios básicos da fé. Em segundo lugar, a Constituição garante a liberdade das pessoas em matricularem-se ou não, uma vez que, conforme, já salientado, a plena liberdade religiosa consiste também na liberdade ao ateísmo.

Anna Cândida da Cunha Ferraz ${ }^{256}$ entende que o ensino religioso nas escolas públicas é uma projeção da liberdade religiosa e que por ser o Estado brasileiro um Estado laico, tal tipo de ensino somente poderia ter sido incluído pela Constituição, configurando, assim, uma exceção à separação entre Estado e Igreja. Bastante interessante é a posição da autora, segundo a qual o ensino tal como previsto constitucionalmente deverá ser um ensino de caráter confessional, pois se assim não fosse o preceito constitucional não seria necessário.

Caberia ao Estado apenas garantir que o ensino religioso seria prestado nos horários normais de aula, desde que houvesse solicitação pelo aluno ou por seus pais ou responsáveis. O ensino não poderia ser ministrado pelo Estado, pois esta seria função das entidades confessionais.

Para a aplicação do ensino religioso, o Poder Público deveria levar em consideração a observância rigorosa da separação, ainda que atenuada, entre Estado e Igreja, interpretando o dispositivo de maneira restritiva. ${ }^{257}$ A liberdade religiosa deveria ser compatibilizada, o que obrigaria o Estado a velar para que o ensino religioso não embaraçasse ninguém nem fosse por alguém embaraçado. $\mathrm{O}$ espaço aberto ao ensino

\footnotetext{
${ }^{255}$ MORAES, 2011, p. 133-4.

${ }^{256}$ FERRAZ, 1997, p.19-47

${ }^{257}$ Parece que, ao contrário do que afirma Anna Cândida da Cunha Ferraz, a interpretação restritiva do parágrafo $1^{\circ}$ do art. 210 levaria à conclusão de que o ensino religioso não poderia ser ministrado de forma confessional, mas sim deveria ter um caráter histórico, acerca da história das religiões.
} 
religioso deveria seguir os parâmetros da educação e do ensino fundamental postos pela Constituição. O Estado deveria ter uma atuação negativa quanto ao conteúdo do ensino religioso, pois sendo o Estado neutro não poderia nele se imiscuir.

Outro desafio a ser enfrentado é a forma de contratação dos professores de ensino religioso. Entende a autora que tais professores não poderiam ser funcionários públicos, para que não houvesse um vínculo entre Estado e membros de religiões. Eis a razão por que afirma a autora que a contratação de tais professores deveria ser resolvida no âmbito das entidades confessionais.

Caberia, sobretudo, ao Estado fiscalizar a ministração do ensino religioso para que a ordem do estabelecimento de ensino não fosse ferida, bem como para garantir o respeito a outros direitos fundamentais.

Ives Gandra $^{258}$ apresenta uma versão mais radical na interpretação da previsão do ensino religioso em escolas públicas. Em primeiro lugar, afirma o autor que há duas disposições claras no preceito constitucional em exame, quais sejam: a obrigatoriedade do ensino religioso nas escolas públicas e a facultatividade da frequência dos que cursam a escola.

Para o autor, o ensino religioso a que faz referência a Constituição seria apenas o ensino confessional da religião Católica Apostólica Romana, cabendo a esta a definição do conteúdo da matéria a ser ensinada. Tal disposição seria compatível com a existência de diversos outros cultos, pois a matrícula na disciplina seria facultativa. Assim, somente matricular-se-iam na disciplina os seguidores da Igreja Católica.

A remuneração dos professores contratados para ministrar o ensino religioso caberia ao Estado, pois seria ele o responsável pela constituição do ensino.

Isso Scherkerkewitz ${ }^{259}$ demonstra a dificuldade de definir com base na disposição constitucional os padrões de conduta do administrador ou dos educadores na criação do ensino religioso, de qual seria seu conteúdo ou mesmo que disciplina alternativa seria disponibilizada para os alunos que não optassem matricular-se nas aulas de ensino religioso.

Não existindo uma religião oficial no Brasil, não poderia o Estado optar pelo ensino de uma única religião, pois feriria a laicidade estatal e geraria um proselitismo

\footnotetext{
${ }^{258}$ GANDRA, Ives. Educação religiosa nas escolas públicas - inteligência do art. 210 da Constituição Federal - opinião legal. Revista de Direito Civil, Imobiliário, Agrário e Empresarial, Sao Paulo, v.20, n.75, jan./mar, 1996. p. 115-123.

${ }^{259}$ SCHERKERKEWITZ, Iso Chaitz, O direito de religião no Brasil. Revista Trimestral de Jurisprudência dos Estados, São Paulo, v.20, n.146, mar. 1996, p. 70-2
} 
patrocinado pelo Poder Público.

Crê o autor que a ideia da Constituição foi permitir que os alunos em idade de formação tenham todos os conhecimentos necessários para que possam optar por uma religião ou ainda por religião nenhuma. Contudo, não admite a possibilidade de que os professores sejam contratados dentro de certa religião. A contratação deveria dar-se por concurso público que impusesse como requisito o conhecimento dos preceitos gerais das principais religiões existentes no Brasil, que seriam: religiões de origem africana, católica, evangélica, judaica, muçulmana, budista.

O autor entende que a facultatividade não existiria de verdade, pois deveria ser dada uma opção aos alunos que não participassem da matéria, o que seria difícil. Ademais, poderia haver uma pressão de alunos que formassem uma maioria a favor de uma religião tradicional sobre outros que não fizessem parte de tal credo.

Após uma breve análise do que seria o ensino religioso no Brasil, conclui o autor que o dispositivo constitucional que o consagra deveria ser revisto, uma vez que se encontra em contradição com o cerne da Constituição que impõe a separação obrigatória entre Estado e Igreja

Aldir Soriano ${ }^{260}$ confere maior importância ao fato de que o ensino religioso seja facultativo, pois a sua obrigatoriedade redundaria em agressão direta à liberdade religiosa. Levando-se em consideração todas as garantias constitucionais referentes à liberdade de consciência, nenhuma matéria de cunho religioso poderia ser ministrada sem o consentimento dos alunos ou dos seus responsáveis.

Esposa ainda o entendimento de que a norma constitucional seria de eficácia limitada, dependendo da edição de lei para que o direito pudesse ser exercido. O cidadão poderia exigir do Estado que cumprisse o seu dever de fornecer o ensino religioso, já que a norma encerra um direito público subjetivo. Porém, a prestação pelo Estado depende de condições administrativas que precisam ser especificadas, tais como uma eventual colaboração com as religiões.

Em doutrina estrangeira, a mesma problemática existe. Na França, a laicidade do ensino foi prevista com o preâmbulo da Constituição de 1946, sendo confirmado como um dever do Estado pela Constituição de $1958 .^{261}$

Considerando a característica obrigatoriamente laica do ensino estatal,

${ }^{260}$ SORIANO, A., 2002, p. 101-2.

${ }^{261}$ JAN, Pascal. La laicité à l'école: le droit national contre le droit local. La loi plutôt que La négociation. Question de valeurs. Revue Du Droit Public de La Science Politique en France et à l'Étranger. Paris, LGDJ, n. 2, 2004, p. 302-3. 
Gérard Gonzalez ${ }^{262}$ expõe a impossibilidade de o Estado ministrar ensino religioso de modo contrário à vontade dos pais.

O autor advoga a ideia de um ensino religioso sem manifestação da fé, mas apenas como uma exposição geral de todas as religiões. Um ensino que tivesse estas bases estaria de acordo com o art. 9 da Convenção Europeia de Direitos Humanos e teria o condão de servir como fundamento ao direito de mudar de religião. Neste sentido, o ensino religioso nesses moldes seria um verdadeiro dever do Estado, pois na sua inexistência, o referido direito de escolher e mudar de religião restaria inócuo.

A Corte afirma o direito de convencer o próximo sobre a sua religião, inclusive através do ensino. $\mathrm{O}$ ensino, visto como um meio intelectual de conversão, poderia ser insistente e intensivo e somente deveria ser combatido se visto como uma forma de lavagem cerebral para convencimento dos demais.

Poderiam ser vislumbrados dois tipos de ensino. Um que pretenderia elevar a consciência do discípulo enquanto parte de uma determinada comunidade. $\mathrm{O}$ outro que teria a pretensão de fornecer os princípios fundamentais que serviriam de base para a escolha do indivíduo em definir a sua religião. Há, porém, um ponto comum entre estes dois tipos de ensino que é o consentimento do aluno que quer ouvir o que há para ser ensinado.

A preocupação no ensino religioso é sempre impedir que através dele seja veiculado um proselitismo de maneira abusiva. Afinal, o mero proselitismo não deveria ser combatido a priori por configurar parte da liberdade religiosa. Analisando os dois tipos de ensino aquele que não configura um proselitismo abusivo seria o segundo tipo.

Tanto é assim que a Corte reconhece o proselitismo como uma maneira de garantir o direito a mudar de religião. O proselitismo, atualmente, costuma ser visto de maneira negativa. A Corte, entretanto, admite o proselitismo como uma forma de promoção do debate, de ensino.

Ressalta o autor que a Corte dá como exemplo as Testemunhas de Jeová que praticam tentativas de conversão das pessoas de maneira bastante acentuada, da mesma forma que impõem aos seus membros regras muito rígidas de conduta. No que tange a tais regras, a Corte não se preocupa com a sua existência, pois a todos é garantido o direito de mudar de religião, se a atual deixar de lhe agradar.

Por mais que pareça irritante a prática do proselitismo, ele pressupõe o

${ }^{262}$ GONZALEZ, 1997, p. 115-120. 
consentimento do outro em ouvir uma nova perspectiva religiosa. Tal concepção retira o caráter abusivo do proselitismo, o que não impede a existência de abusos individuais a serem coibidos. A possibilidade de abusos individuais diminui bastante à medida que o proselitismo é praticado por meio do ensino. Afinal, o ensino prevê um acordo prévio entre as duas partes.

No Brasil, a única experiência com tentativa de ensino religioso deu-se com a edição de leis no Rio de Janeiro, uma estadual e outra municipal. A lei estadual, datada de 2000, já foi objeto de Ação Direta de Inconstitucionalidade.

Espera-se que o Supremo Tribunal Federal pronuncie-se em breve acerca do ensino religioso em escolas públicas, tendo em vista o ajuizamento da ADI 3.268, contestando a Lei 3.459/00 do Estado o Rio de Janeiro que institui o ensino religioso confessional nas escolas públicas daquele Estado.

A petição inicial da ação direta de inconstitucionalidade alega que os dispositivos impugnados ${ }^{263}$ chocam-se com a impessoalidade da administração e com o laicismo do Estado. Fere o art. $210, \S 1^{\circ}$ da $\mathrm{CF}$, que previu o modelo ecumênico para o ensino religioso, já que o ensino instituído pela lei foi o confessional.

A lei impugnada acabaria criando uma vinculação entre o Estado e as Religiões, o que violaria o art. 19, I da CF. De acordo com a lei estadual o professor da religião deveria ser credenciado perante a autoridade religiosa e nem todas as religiões possuem uma estrutura hierárquica - nem todas as crenças foram contempladas pela lei, o que gera uma distinção dos cidadãos em função do credo (violação do art. $5^{\circ}$, VIII). Somente não haveria inconstitucionalidade na lei se ela conferisse as mesmas possibilidades para todas as religiões.

A Lei 5.303/11 do Município do Rio de Janeiro criou 600 cargos de

\footnotetext{
${ }^{263}$ Art. $1^{\circ}$ - O Ensino Religioso, de matrícula facultativa, é parte integrante da formação básica do cidadão e constitui disciplina obrigatória dos horários normais das escolas públicas, na Educação Básica, sendo disponível da forma confessional, de acordo com as preferências manifestadas pelos responsáveis e pelos próprios alunos a partir de 16 anos, inclusive assegurado o respeito à diversidade cultural e religiosa do Rio de Janeiro, vedadas qualquer forma de proselitismo.

Parágrafo único - No ato da matrícula, os pais, ou responsáveis pelos alunos deverão expressar, se desejarem que seus filhos ou tutelados frequentem as aulas de Ensino Religioso.

Art. $2^{o}$ - Só poderão ministrar aula de Ensino Religioso, nas escolas oficiais, professores que atendam às seguintes condições:

I- Que tenham registro no MEC, e de preferência que pertençam aos quadros do Magistério Público Estadual.

II- Tenham sido credenciados pela autoridade religiosa competente, que deverá exigir do professor, formação religiosa obtida em instituição por ela mantida ou reconhecida.

Art. $3^{\circ}$ - Fica estabelecido que o conteúdo do ensino religioso é atribuição específica das diversas autoridades religiosas, cabendo ao Estado o dever de apoiá-lo integralmente.
} 
professor de ensino religioso no quadro permanente de pessoal do Poder Executivo do Município.

A admissão dos professores de ensino religioso ocorrerá através de concurso público de provas e títulos e os professores deverão ser credenciados pela autoridade religiosa competente, além de terem obtido formação religiosa em instituição por ela mantida ou reconhecida.

De acordo com a lei, o ensino religioso terá caráter plural e facultativo, devendo ser priorizada a sua implantação em escolas de turno integral. A lei preocupa-se bastante em enfatizar o caráter facultativo da matrícula, dispondo inclusive sobre o anúncio, dirigido aos pais e responsáveis, a ser fixado nas escolas para divulgar a facultatividade da disciplina religiosa.

A lei incorre nas mesmas dificuldades já apontadas doutrinariamente sobre a implantação do ensino religioso nas escolas públicas. Que a disciplina religiosa deve ser facultativa não há qualquer dúvida. O grande problema reside em como cumprir a disposição legal de que o ensino, além de facultativo, deve ser plural. Será possível e viável a criação de uma disciplina específica para cada religião existente?

Ademais, sendo o Estado laico poderia ele contratar pessoas diretamente ligadas a uma confissão religiosa? Sendo os professores credenciados por uma autoridade religiosa o caráter da disciplina seria proselitista ou teria um viés da história das religiões.

A existência de uma previsão específica na Constituição sobre ensino religioso leva a crer que o intuito seria criar uma disciplina que ensinasse os preceitos da religião como expressão da fé. Afinal, o mero ensino imparcial da história das religiões não necessitaria de autorização constitucional específica.

Para que tal tipo de ensino fosse possível frente à previsão de laicidade estatal, os ministros de religião não deveriam manter qualquer tipo de vínculo com o Poder Público, sob pena de o Estado subvencionar confissões religiosas em ofensa ao art. 19, I.

Interessante será observar os desdobramentos na aplicação na lei, bem como o desfecho da ADI em curso no STF.

A Corte Europeia de Direitos humanos já enfrentou casos de ensino religioso. Em 1997, o programa de ensino da Noruega foi modificado ao substituir duas disciplinas existentes, uma sobre cristianismo e outra sobre a religião e a filosofia, por uma única, cristianismo e a filosofia da vida. Os requerentes tentaram em vão pedir dispensas 
para seus filhos da referida aula.

A Corte decidiu pela violação ao artigo 2 do Protocolo 1 (direito à instrução), por entender que a nova disciplina daria uma importância maior ao cristianismo. Além disso, o mecanismo de dispensas parciais poderia submeter os pais ao risco de que suas vidas particulares fossem expostas e ainda que a eventual possibilidade de conflitos dissuadisse os pais a requerer a dispensa. ${ }^{264}$

$\mathrm{Na}$ Alemanha, surgiu contestação de um aluno e seus pais a uma lei datada de 2006 que introduziu no ensino público de Berlim uma disciplina obrigatória de ética. De acordo com os requerentes, tal curso feriria as suas convicções protestantes. A demanda não mereceu acolhida na Corte Constitucional Alemã. A Corte Europeia de Direitos Humanos rejeitou a demanda sob o argumento de que o curso de ética tinha como objetivo enfrentar questões fundamentais de ética, independentemente das origens culturais, étnicas, religiosas ou ideológicas dos alunos. ${ }^{265}$

\section{III.7- Feriados religiosos}

Sendo o Brasil um Estado Laico, conforme disposto no art. 19, I da CF/88, diversos questionamentos surgem sobre uma possível confusão entre Estado e questões religiosas. Não é pelo fato de o Estado ser laico que não pode haver nenhuma relação do Estado com a religião. A questão que se põe é apenas em que medida esta intervenção fere os princípios constitucionais.

Os desdobramentos do princípio da laicidade do Estado revelam-se de diversas maneiras na prática. Um deles é a possibilidade de criação de feriados religiosos, vejamos como se pronuncia a jurisprudência:

\section{DANOS MORAIS. LEI QUE INSTITUIU O DIA DO EVANGÉLICO. CONSTITUCIONALIDADE. LIBERDADE DE CULTO. 1 - A Constituição Federal, no art. 19, I, veda a União, os Estados, o Distrito Federal e os Municípios, estabelecer cultos religiosos ou igrejas, subvencioná-los, embaraçar-lhes o funcionamento ou manter com eles ou seus representantes}

\footnotetext{
${ }^{264}$ CORTE EUROPEIA DE DIREITOS HUMANOS - Folgero e outros v. Noruega (n. 15472/02) - Julgado em 19/06/07 - Disponível em http://www.echr.coe.int/NR/rdonlyres/E0941C75-D511-487B-A99155A7074B5E59/0/FICHES_Liberté_religion_FR.pdf - Acesso em 11/05/2011

${ }^{265}$ CORTE EUROPEIA DE DIREITOS HUMANOS - Appel-Irrgang v. Alemanha - Julgado em 06/10/09 Disponível em http://www.echr.coe.int/NR/rdonlyres/E0941C75-D511-487B-A99155A7074B5E59/0/FICHES_Liberté_religion_FR.pdf - Acesso em 11/05/2011
} 


$$
\text { relações de dependência ou aliança. }
$$

2 - Não pró́be que algum desses entes da federação, no exercício de sua competência legislativa, institua data comemorativa, a exemplo do que fez o Distrito Federal, quando instituiu dia do evangélico. 3 - Não é, portanto, inconstitucional lei assim editada. E os atos cometidos com base nela são válidos, como sói acontecer com a comemoração do dia do evangélico que se caracteriza exercício regular de um direito -- o de culto religioso (CF, art. $5^{\circ}$, VI). E quem exerce um direito, salvo abuso, não causa dano a outrem (CC, art. 160, I).

4 - Vislumbrar em situações que tal preconceito ou discriminação é emprestar razão à intolerância religiosa, praga que, ao longo da história, tem feito e continua fazendo inúmeras vítimas.

5 - Apelação não provida. ${ }^{266}$

No caso citado, trata-se da criação de um feriado referente a uma religião que se pode dizer não tradicional. O calendário brasileiro está repleto de feriados religiosos católicos, que não são contestados em razão da tradição brasileira ligada à Igreja Católica. Aparentemente, os questionamentos começam a surgir quando está em foco o "favorecimento" a uma religião não católica.

O TJ-DF entendeu que a vedação do art.19, I da CF/88 não impede que um ente da federação crie datas comemorativas ligadas a algumas religiões. Este tema além de mostrar que a laicidade do Estado não impede que o Poder Público tenha relações com Igrejas e nem que isso aconteça sem ferir o princípio da tolerância religiosa e demais dispositivos constitucionais.

A criação de feriados religiosos para compor o calendário nacional envolve a necessidade de a data ter relevância para a sociedade e não representar apenas uma data celebrada apenas por parcela minoritária da população. Tal posicionamento não afronta a laicidade do Estado, uma vez que seria impossível contemplar todas as religiões com feriados religiosos.

Ante a impossibilidade de criação de feriados para todas as datas importantes para todas as religiões, o que deve ser resguardada é a possibilidade de os indivíduos gozar de descanso nos dias considerados sagrados para a sua religião. Tratandose de questões trabalhistas deve prevalecer o princípio do boa-fé. Assim, devem as datas

${ }^{266}$ TJ-DF - 20010110875766APC, Relator JAIR SOARES, $4^{a}$ Turma Cível, julgado em 05/11/2001, DJ $27 / 02 / 2002$ 
religiosas ser respeitadas pelo empregador ou pelo Estado, de maneira geral, caso seja avisado com antecedência os dias sagrados que deverão ser respeitados.

Veja-se neste sentido acórdão do TRT da $2^{\mathrm{a}}$ Região:

AUSÊNCIA À AUDIÊNCIA - FERIADO RELIGIOSO. NÃO EXISTE PREVISÃO LEGAL QUE JUSTIFIQUE A AUSÊNCIA DA PARTE DEVIDO A FERIADO RELIGIOSO NÃO RECONHECIDO NACIONALMENTE, AINDA MAIS QUANDO, NOTIFICADA ANTECIPADAMENTE, NÃO SOLICITAR ANTECIPAÇÃO OU ADIAMENTO DA MESMA. ${ }^{267}$

O acórdão ressalta a inexistência de previsão legal que justifique a ausência por feriado religioso não reconhecido. Salienta ainda que a omissão da parte em informar a sua impossibilidade de comparecimento, o que eventualmente poderia ser motivo suficiente para adiamento da audiência.

O mesmo raciocínio vale para a relação de trabalho. Se, no momento da contratação, a pessoa informar ao empregador a sua impossibilidade de comparecimento em dias determinados, por motivos religiosos, em respeito à liberdade de crença devem tais dias serem respeitados pelo empregador. Contudo, o aviso posterior à contratação, demonstrando má-fé do empregado, não obriga o empregador.

Neste sentido, pronuncia-se Canamares Arribas ${ }^{268}$ ao tratar da liberdade religiosa no ambiente laboral. $\mathrm{O}$ autor relembra que a doutrina e a jurisprudência entendem que os trabalhadores permanecem no gozo de seus direitos fundamentais no âmbito da iniciativa privada. Deve haver assim uma harmonização entre o direito do trabalhador e a liberdade empresarial.

O Tribunal Superior de Justiça da Espanha entendeu que a liberdade religiosa dos trabalhadores deve ser respeitada pelos empregadores, adequando as normas das empresas às crenças dos trabalhadores. Contudo, estes devem agir de boa-fé e avisar antes da contratação que pertencem à determinada crença religiosa, para que a empresa possa analisar se pode adequar as necessidades do trabalhador com o desenvolvimento de suas atividades. Para o autor, a boa-fé seria, assim, um limite aos direitos fundamentais no ambiente laboral.

${ }^{267}$ TRT-2 - $1^{\text {a }}$ Turma - Recurso Ordinário 02950427566 - Rel. Wagner José de Souza - Julgado em 23/04/1997 - Publicado em 19/05/1997.

${ }^{268}$ CANAMARES ARRIBAS, 2006, p. 330-3. 


\section{III.8- Provas de concursos}

Tema bastante presente é a guarda do dia de sábado por algumas religiões, a impedir, portanto, que seus seguidores participem de concursos ou aulas marcados para tal dia. O tratamento pela jurisprudência quanto ao respeito do sábado altera-se de acordo com a natureza do evento coletivo a que o requerente pretende furtar-se. Frequentemente classifica-se a alegação de impossibilidade de prática de atividades aos sábados como um exemplo de escusa de consciência.

Um caso bastante comum é o pedido de realização de prova de concurso público, marcada para sábado, em dia diverso. O STF, em julgamento de Agravo Regimental em Suspensão de Tutela Antecipada, negou o pedido de participação de estudantes judeus no ENEM em data diversa do Shabat, por entender que: "a designação de data alternativa para a realização dos exames não se revela em sintonia com o principio da isonomia, convolando-se em privilégio para um determinado grupo religioso. ${ }^{269}$

É interessante salientar que pode ocorrer uma mudança de posicionamento no STF, uma vez que foi reconhecida repercussão geral no RE 611874, que trata do tema.

No mesmo sentido, posicionou-se o $\mathrm{STJ}^{270}$, ao entender que a liberdade religiosa, tal como assegurada pela Constituição não pode servir de fundamento para a criação de privilégios a candidatos que professem uma determinada crença. Por esta concepção, o princípio da isonomia que rege o concurso público deveria prevalecer sobre o direito à liberdade de consciência.

O pedido de mudança de dia de prova de concurso é realizado normalmente por integrantes da Igreja Adventista do Sétimo Dia, já que estes consideram o sábado um dia sagrado. Também privilegiando a isonomia característica dos concursos públicos, entendeu o Tribunal de Justiça de São Paulo que a previsão de prova no sábado não é ilegal, nem fere os princípios inscritos no art. $5^{\circ}$, VI e VII da Constituição Federal. ${ }^{271}$

Bastante sintético acerca do embate entre a liberdade religiosa e as regras da Administração Pública é o julgado do Tribunal de Justiça do Maranhão ${ }^{272}$, assim ementado:

\footnotetext{
${ }^{269}$ STF - Pleno - AgR 389 - Rel. Min. Gilmar Mendes - Julgado em 03/12/2009 - DJ 13-05-2010.

${ }^{270}$ RMS 22.825/RO - 5 ${ }^{\text {a }}$ Turma - Rel. Ministro FELIX FISCHER - Julgado em 26/06/2007 - DJ 13/08/2007 p. 390

${ }^{271}$ TJ-SP - Agravo de Instrumento 994061025297 (6094365800) - Rel. Desembargador Urbano Ruiz - Órgão julgador: $6^{\text {a }}$ Câmara (Extinto $1^{\circ}$ TAC) - Data de registro: 06/07/2007

${ }^{272}$ TJ-MA - $3^{\text {a }}$ Câmara Cível - AgI 023697-2006 - Rel. Des. Stélio Muniz
} 
ADMINISTRATIVO. CONCURSO PÚBLICO. CONFRONTO ENTRE O PRINCÍPIO DA LIBERDADE RELIGIOSA E OS DA ADMINISTRAÇÃO PÚBLICA. PREVALÊNCIA DESTES ÚLTIMOS.

Muito embora seja constitucionalmente garantida a liberdade religiosa, devem se assumir os ônus e os riscos daí decorrentes, notadamente quando do confronto de tal escolha com outros princípios constitucionais, como os que regem a administração pública, que não permitem trata mento diferenciado entre candidatos de concurso público, como entende o STJ.

Há, contudo, manifestação diversa do TJ-SP para que se faça prevalecer a liberdade religiosa, entendendo que não haveria qualquer prejuízo ao certame a realização da mesma prova em data diversa da oficialmente marcada. ${ }^{273} \mathrm{Na}$ mesma linha decidiu o Tribunal de Justiça da Bahia, ao admitir que a consagração da liberdade religiosa e a consequente impossibilidade de discriminação das práticas religiosas impede que sejam criados obstáculos à participação em concurso público de candidatos, cuja religião imponha a guarda sabática. ${ }^{274}$

Fator que parece ser de importante relevância para a definição da possibilidade de mudança da data da prova de um concurso é a eventual criação de privilégios ou desigualdade entre os candidatos. Afinal, a realização de uma prova escrita num concurso público deve, necessariamente, ser simultânea para todos os candidatos de tal modo que não haja possibilidade de que nenhum candidato tenha conhecimento do conteúdo da prova antes de sua realização.

Tal elemento é ponderado pelo Tribunal de Justiça do Rio Grande do Sul ${ }^{275}$, ao entender que diferentemente do que ocorre com uma prova escrita, uma prova prática poderia ser realizada em dias diferentes. In verbis:

\begin{abstract}
APELAÇÃO EM MANDADO DE SEGURANÇA. CONCURSO PÚBLICO. CARGO DE MOTORISTA. CREDO RELIGIOSO. PROVA PRÁTICA. PERDA DO OBJETO. Perda do objeto: Inocorrência de perda do objeto, em razão da realização da fase concursal discutida. Prova de natureza prática, que não requer a realização simultânea com os demais candidatos, como seria exigido na prova escrita. Possibilidade de realização em momento posterior Colisão de princípios constitucionais:
\end{abstract}

\footnotetext{
${ }^{273}$ TJ-SP - Apelação 994050154759 (4533245600) - Rel. Des. Antonio Carlos Malheiros - Data de registro: 20/07/2006

${ }^{274}$ TJ-BA - Agravo 8-1/2007 - Rel. Des. Gardenia Pereira Duarte - 4a Câmara Cível - Data do Julgamento 20/06/2007. No mesmo sentido: TJPR - IV Gru. de C.Cíveis - MS 0132338-8 - Curitiba - Rel.: Des. Celso Rotoli de Macedo - Por maioria - J. 27.03.2003

${ }^{275}$ TJ-RS - Apelação Cível No 70024269748, Terceira Câmara Cível, Relator: Paulo de Tarso Vieira Sanseverino, Julgado em 26/06/2008. No mesmo sentido da admissibilidade de mudança da prova prática: TJ-MG - MS 1.0145.07.377345-2/001(1) - Rel. Des. Belizário Lacerda - Julgado em 29/04/2008 - D.J. $05 / 06 / 2008$
} 
Possibilidade, no caso concreto, de se dar prevalência ao direito fundamental da liberdade de crença religiosa sobre o princípio da legalidade. Permissão de realização da prova no segundo dia das provas práticas. Prevalência do princípio da convicção religiosa dos impetrantes sem grave afronta aos princípios da legalidade e da isonomia. SEGURANÇA CONCEDIDA. SENTENÇA REFORMADA. APELAÇÃO PROVIDA.

Como todo direito fundamental, sendo a liberdade religiosa relativa, é possível entender que o princípio da isonomia que rege os concursos públicos deva prevalecer sobre a liberdade religiosa.

Caso em que parece ressaltar ainda mais a necessidade de supremacia do interesse público sobre a liberdade religiosa do indivíduo é o pedido, relativamente frequente na jurisprudência, realizado policias militares para abono de faltas no período correspondente ao pôr-do-sol de sexta-feira até o pôr-do-sol de sábado.

O Tribunal de Justiça de São Paulo, ao analisar a referida situação, vislumbrou um conflito entre o princípio da autonomia administrativa e a supremacia do interesse público de um lado e a liberdade religiosa de outro, decidindo pela prevalência da supremacia do interesse público. ${ }^{276}$

Pela supremacia do interesse público também surge o julgado do Tribunal de Justiça do Sergipe, salientando que a liberdade religiosa por não ser absoluta "encontra limite na medida em que ameaça outros princípios também fundamentais, in casu, os princípios da igualdade, legalidade, eficiência e segurança jurídica."277

Tais julgados reconhecem que a função exercida pelos Policiais Militares é de tal importância que não pode sofrer solução de continuidade ainda que sob o fundamento de garantia da liberdade religiosa. $\mathrm{O}$ dano que seria causado pela possibilidade de não comparecimento de policiais militares no período de sexta para sábado seria assaz gravoso para a manutenção da ordem pública.

Diferentemente ocorre com o pedido de alunos integrantes da Igreja Adventista do Sétimo Dia de abono por faltas na sexta-feira à noite e sábado. Exatamente

\footnotetext{
${ }^{276}$ TJ-SP - 9a Câmara de Direito Público - Apelação 990100911724 - Rel. Des. Rebouças Carvalho Julgado em 19/05/2010 - Data do registro 26/05/2010

${ }^{277}$ TJ-SE - Apelação Cível No 4350/2008, $3^{\text {a }}$ Vara Cível, Relator: DES. JOSÉ ALVES NETO, Julgado em 20/10/2008. No mesmo sentido: TJ-SE - AgI 0322/2007, $3^{\text {a }}$ Vara Cível, Relator: DES. JOSÉ ALVES NETO, Julgado em 30/06/2008.
} 
por não haver, em princípio, violação a direitos fundamentais alheios, a jurisprudência ${ }^{278}$ é praticamente unânime em respeitar o credo dos alunos e permitir a falta em dias sagrados.

Julgado do Tribunal de Justiça do Distrito Federal ${ }^{279}$ demonstra com bastante propriedade a ponderação feita pelos Tribunais, em sua maioria, acerca da necessidade de as Universidades respeitarem a liberdade religiosa de seus alunos, de modo a permitir que haja a falta em dias sagrados. Segue a ementa:

REMESSA OFICIAL EM MANDADO DE SEGURANÇA. DIREITO CONSTITUCIONAL E DIREITO ADMINISTRATIVO. CONCURSO PÚBLICO. LIBERDADE DE CONSCIÊNCIA E DE CRENÇA. ADVENTISTA. PRESERVAÇÃO DO DIA DE SÁBADO.

1. A Constituição Federal de 1988, distintamente da Carta de 1967/69 que só assegurava o direito à liberdade de consciência, protege tanto a liberdade de consciência quanto a de crença. O texto constitucional em vigor respalda todas as crenças, pois o Estado Democrático de Direito consagra a máxima liberdade religiosa. Em razão dessa proteção firmada em torno da liberdade de consciência e crença, a Constituição estabelece (artigo $5^{\circ}$, inciso VIII) que ninguém será privado de direitos por força de motivo de crença religiosa ou de convicção filosófica ou política, salvo se a invocar para eximir-se de obrigação legal a todos imposta e recusar-se a cumprir prestação alternativa fixada em lei (escusa de consciência).

2. O candidato adventista que participa do curso de formação para o cargo de Auxiliar de Trânsito da Secretaria de Estado de Planejamento e Gestão do Distrito Federal, promovido pelo Centro de Seleção e de Promoção de Eventos - CESPE, tem o direito de dispensa ou abono da falta nas atividades a serem realizadas no sábado em razão de respeito às suas convicções religiosas, devendo ser nomeado e empossado no cargo pretendido, caso seja aprovado dentro do número de vagas.

Divergindo da linha predominante na jurisprudência, o Tribunal de Justiça do Paraná ${ }^{280}$ entendeu que sendo o Estado brasileiro um Estado laico, não deve a Administração Pública, isto é, a Universidade Pública, fazer diferenciação entre as diversas religiões e alterar suas regras sobre aulas e avaliações. $\mathrm{O}$ aluno que ingressa numa Universidade Pública deve adequar-se às regras preexistentes.

Aqui parece haver uma confusão entre laicidade do Estado e intolerância religiosa. O Estado, ao ser laico, não deve reconhecer nenhuma religião oficialmente, mas

\footnotetext{
${ }^{278}$ TJ-SP - AgI 990092900820 - 32 $2^{\text {a }}$ Câmara de Direito Privado - Rel. Des. Walter Cesar Exner - Julgado em $08 / 04 / 2010$ - Data de registro 26/04/2010

${ }^{279} 20090110529213 R M O$, Relator WALDIR LEÔNCIO C. LOPES JÚNIOR, $2^{\text {a }}$ Turma Cível, julgado em 10/03/2010, DJ 06/04/2010 p. 71. No mesmo sentido: TJ-MS - Apelação Cível 2010.017905-2 - 3 ${ }^{\text {a }}$ Turma Cível - Rel. Des. Marco André Nogueira Hanson - Publicação 08/09/2010; TJ-BA - AgI 26589-2/2009 - 2a Câmara Cível - Rel. Des. Maria do Socorro Barreto Santiago - Julgado em 06/10/2009; TJ-GO - Apelação Cível em Mandado de Segurança 119734-8/189 - $3^{\text {a }}$ Câmara Cível - Rel. Des. Felipe Batista Cordeiro - DJ 01/07/2008

${ }^{280}$ TJPR - 6 C.Cível - AC 0546729-6 - Maringá - Rel.: Des. Prestes Mattar - Unânime - J. 09.06.2009
} 
deve respeitar a crença de seus cidadãos. A laicidade não pode significar hostilidade à religião, o Estado não deve punir seus cidadãos de agir de acordo com a sua crença. É, portanto, obrigação do Estado respeitar a crença dos cidadãos, se a sua manifestação não ferir outros direitos fundamentais ou o interesse público.

Bastante interessante é a análise feita pelo Tribunal de Justiça do Espírito Santo $^{281,}$ quanto à possibilidade de imposição de prestação alternativa pelo Judiciário em face da ausência de alunos em aulas de sábado. Define o acórdão que não cabe ao Judiciário a imposição de prestações alternativas, uma vez que não há previsão legal. Afirma, ainda, que não havendo lei infraconstitucional que crie prestação alternativa relacionada a imperativo de consciência e direitos individuais, não existiria o direito para descumprimento dever a todos imposto.

A discussão, neste ponto, não demonstra, a princípio, uma predileção específica a uma determinada religião. Afinal, as decisões judiciais têm sido bastante coerentes em privilegiar a isonomia do concurso público à liberdade religiosa de alguns indivíduos. A realização de prova em dia diverso por apenas alguns candidatos, de fato, afrontaria o art. $37 \mathrm{da} \mathrm{CF} / 88$ e minaria a finalidade do concurso.

Pode ser contestada, contudo, a decisão da Administração de marcar provas de concurso no sábado, tendo ciência de que tal dia irá impedir a participação de candidatos de determinada religião. Tal decisão pode sim demonstrar a falta de preocupação do Estado em resguardar a possibilidade de que os candidatos, independentemente de sua religião, inscrevam-se no concurso.

\section{III.9- Aborto}

Questão bastante controvertida e que envolve fortes convicções religiosas é a referente à legalidade ou à possibilidade de legalização do aborto. Mesmo em países em que o Estado e a Igreja são separados, a discussão sobre o aborto envolve sempre uma batalha entre seitas religiosas. Os argumentos relacionados ao aborto invocam frequentemente a necessidade de reflexão sobre o valor intrínseco da vida humana. ${ }^{282}$

${ }^{281}$ TJ-ES - AgI 024009005422 - 1 ${ }^{\text {a }}$ Câmara Cível - Rel. Des. Arnaldo Santos Souza - Julgado em 07/08/2001

${ }^{282}$ DWORKIN, Ronald. Domínio da vida - aborto, eutanásia e liberdades individuais. São Paulo: Martins Fontes, 2009, p. 48-52. 
O tema ganhou maior relevância, no ordenamento jurídico brasileiro, com a impetração da Arguição de Descumprimento de Preceito Fundamental (ADPF) n. 54 perante o Supremo Tribunal Federal.

A Confederação Nacional dos Trabalhadores da Saúde (CNTS) impetrou a ADPF perante o STF para que os arts. 124 a 128 do Código Penal (que tratam do aborto) fossem interpretados conforme a Constituição Federal, de modo que a antecipação terapêutica do parto, em caso de feto anencefálico, não fosse considerada aborto.

A questão tanto envolve aspectos religiosos que requereram o ingresso como amicus curiae a Confederação Nacional dos Bispos do Brasil (CNBB), Católicas pelo Direito de Decidir, dentre outras entidades de cunho religioso.

A arguente alega que a antecipação terapêutica do parto não pode ser considerada aborto, pois, no caso da anencefalia, o feto não tem qualquer possibilidade de vida extrauterina.

Com a ADPF, pretende a CNTS que o STF declare que os referidos artigos do CP não poderão ser interpretados pelos juízes, de modo a considerar aborto a antecipação terapêutica do parto na anencefalia.

A CNTS demonstra ter interesse no oferecimento da ADPF, pelo fato de os profissionais da saúde estarem sujeitos à ação penal pública, quando realizam "aborto" de feto anencefálico. Quer, portanto, ver realizada a sua pretensão de que esse tipo de antecipação do parto não seja considerada como crime de aborto.

A ADPF 54 entrou no STF em 17/06/2004 e tem como relator o Min. Marco Aurélio Mello. Em 01/07/2004, portanto durante o recesso do Tribunal, o Min. Relator concedeu uma liminar permitindo a antecipação terapêutica em caso de feto anencefálico. A liminar não foi referendada pelos outros Ministros do Supremo.

Em 20/10/2004, foi julgada questão de ordem sobre a ADPF 54. O Supremo, antes de discutir o mérito, entendeu por bem discutir o cabimento ou não da ADPF, para o pedido que está sendo feito pela CNTS. O julgamento foi suspenso pelo pedido de vista do Min. Carlos Ayres Britto. Nesse mesmo dia, por proposta do Min. Eros Grau, o STF acabou também deliberando acerca da liminar concedida pelo Min. Marco Aurélio. O Tribunal decidiu, por maioria, que a liminar deveria ser cassada.

Ultrapassado julgamento da questão de ordem em que se discutia a adequação da ADPF para os fins pretendidos pela referida ação, convocou o Supremo Tribunal Federal audiência pública a fim de permitir um amplo debate. Encerrado o 
período destinado à realização da audiência pública, ainda pende de julgamento o mérito da arguição.

Nos EUA, a decisão da Suprema Corte que permitiu a realização do aborto foi Roe v. Wade ${ }^{283}$.

Roe, uma mulher grávida, questionou a constitucionalidade da lei do Texas que criminalizava o aborto, exceto se o aborto fosse necessário para preservar a vida da mãe. A Suprema Corte entendeu que qualquer lei que criminalizasse o aborto sem considerar o estágio da gravidez seria inconstitucional por ferir o devido processo legal garantido pela $14^{\mathrm{a}}$ Emenda. Tal direito garantiria a privacidade do indivíduo contra a ingerência indevida do Estado, inclusive no que tange à possibilidade de interrupção da gravidez.

Justice entende que a Constituição Americana não define o conceito de vida, mas aparentemente as garantias constitucionais começam após o nascimento. Não cabe ao Judiciário definir quando a vida começa, principalmente, se as áreas médicas e científicas não chegam a um consenso. Toma-se como ponto fundamental para decisão o momento em que o feto torna-se viável, o que pode ocorrer a partir de 24 semanas.

Até o fim do primeiro trimestre em que a taxa de mortalidade na realização de aborto é menor que nos partos. Assim, neste período o médico junto com o seu paciente deve analisar a viabilidade do aborto, podendo realizá-lo sem qualquer intervenção estatal.

A partir do momento em que o feto tem viabilidade fora do útero, com o intuito de proteger a potencialidade da vida humana, o Estado pode regular e até mesmo proibir a realização do aborto, exceto quando for necessário para salvar a vida da mãe.

Ronald Dworkin ${ }^{284}$ faz uma análise bastante profunda sobre as repercussões de tal decisão. Segundo o autor, para os críticos da decisão, a Suprema Corte autorizou o homicídio, uma vez que o feto seria considerado vida a partir do momento da concepção. Alguns críticos não refutam os argumentos da Corte, mas apenas entendem que não caberia aos juízes, mas sim ao legislador determinar se e quando o aborto seria permitido.

O autor afirma que a maioria dos críticos da decisão não entende os argumentos constitucionais que envolvem a decisão Roe v. Wade. A impossibilidade de realização do aborto por uma mulher que acaba de engravidar impõe-lhe uma espécie de escravidão e impede que a mulher exerça liberdade de disposição sobre o próprio corpo.

283 EUA - Suprema Corte - Roe vs. Wade - Julgado em 22/01/1973 - Disponível em http://www.law.cornell.edu/supct/html/historics/USSC_CR_0410_0113_ZS.html

${ }^{284}$ DWORKIN, 2009, p. 141-235. 
Ainda crê interessante relembrar que muitos abortos ilegais foram praticados antes da sentença e arriscando a vida e a saúde das mulheres.

A interpretação que tem sido dada à Constituição Americana pela Suprema Corte tende evitar que o Estado cause danos permanentes aos cidadãos, fazendo com que as leis passem por testes de constitucionalidade. O mais importante é o devido processo legal, pelo qual o Estado não poderia limitar a liberdade dos cidadãos sem um motivo razoável. A Constituição escolhe algumas liberdades e os transforma em direitos fundamentais.

O Juiz Blackmun entende que o direito à privacidade da mulher envolve inclusive questões de procriação e que nenhum Estado teria razões suficientes para anular esse direito até o sexto mês de gravidez. Já, por sua vez, o Juiz Rehnquist, em voto dissidente, entende que as mulheres não têm qualquer direito constitucional de controlar a procriação.

O autor propõe-se a refutar todas as críticas constitucionais feitas a Roe $v$ Wade, principalmente as que se referem ao tratamento especial que se pretende dar ao feto e à discussão acerca da possibilidade de o Estado impor sua concepção majoritária de sagrado sobre todos.

A grande questão que envolve a problemática do aborto e que se relaciona com a questão religiosa é o eventual reconhecimento de vida ao feto, tanto que aqueles que condenam o aborto o fazem sob o manto de proteção da vida humana. Dworkin relembra que tal discussão teve que ser enfrentada inicialmente pela Suprema Corte, uma vez que a $14^{\mathrm{a}}$ Emenda dispõe que todas as pessoas devem receber igual tratamento. Obviamente que o feto não foi entendido como pessoa constitucional, pois se assim o tivesse sido não haveria qualquer outra discussão.

A ideia de que o feto tem vida desde a concepção encontra-se baseada em argumentos teológicos, mas que não deveriam ser considerados num debate constitucional uma vez que a Constituição impõe a separação entre o Estado e a Igreja. O autor relembra que argumentos religiosos não podem ser aceitos juridicamente. A diferenciação feita pelo autor entre a concepção religiosa e a constitucional é bastante interessante.

Dworkin pondera que ainda que uma pessoa considere, por suas convicções religiosas, que o feto tem vida desde a concepção, pode manter as suas convicções, mas compreender que juridicamente elas não podem ser aceitas em razão da laicidade estatal. Para fins jurídicos interessa apenas a visão constitucional. 
O Juiz Blackmun lembra que os fetos nunca foram considerados pessoas constitucionais na história jurídica americana.

Caso o feto fosse considerado pessoa constitucional, não seria dado ao Estado, sob qualquer razão, permitir o aborto, uma vez que haveria agressão à vida. Pelo entendimento da Suprema Corte, no sentido de que o feto não goza de status de pessoa constitucional, a conclusão é que não há nenhuma razão jurídica para que o Estado criminalize o aborto.

Para quem defende que a decisão Roe $v$. Wade deve ser revogada argumenta que a Constituição dos EUA não fala expressamente em direito ao aborto, nem parece este direito ter feito parte da intenção inicial dos políticos que a redigiram.

Uma das questões que se coloca é se o Estado deveria proteger a santidade da vida humana como um valor intrínseco. O autor entende que o Estado pode perfeitamente proteger valores da sociedade, tais como a cultura, o meio ambiente e aceita ainda que a realização do aborto, mesmo que seja uma decisão individual, terá efeitos coletivos.

Dworkin identifica a noção do sagrado como um tabu, entendendo mais fácil manter o tabu contra o aborto do que refutá-lo. A questão que envolve o aborto põe em conflito duas tradições no direito constitucional, quais sejam, a proteção da liberdade por um lado e a responsabilidade do governo em proteger a moralidade do espaço público por outro. As posições contrárias e favoráveis ao aborto concordam que o Estado tem obrigação de garantir a santidade e a inviolabilidade da vida humana.

Admitindo a tese da responsabilidade, surge também a questão da conformidade. O Estado pode exigir que as pessoas ajam de acordo com aquilo que elas consideram responsáveis ou de acordo com o que a maioria da sociedade entenda razoável. Nos dois casos, trata-se de responsabilidade, mas no segundo há na verdade conformidade.

Se pretendemos a responsabilidade, no final devemos deixar os cidadãos livres para decidir como lhes parecer melhor, pois é isso que implica a responsabilidade moral. Contudo, se nosso objetivo for a conformidade, exigiremos, ao contrário, que os cidadãos ajam de maneira de uma maneira que poderia ser contrária a suas próprias convicções morais; isso os desestimula, em vez de incentivá-los a desenvolver ser próprio senso de quando e por que a vida é sagrada. ${ }^{285}$

${ }^{285}$ DWORKIN, 2009, p. 210. 
Tratar o feto como uma vida humana obscureceria esta decisão entre responsabilidade e conformidade. A Constituição dos EUA obviamente considera o debate da vida humana de extrema relevância. Devendo o Estado perseguir o objetivo de responsabilidade, a grande diferença reside entre promover este objetivo e forçar uma decisão.

$\mathrm{O}$ autor ressalta que a opinião das pessoas costuma estar interligada às escolhas estruturais da sua vida. E tal interligação costuma ser mais acentuada em pessoas religiosas. Muitas vezes, contudo, não é apenas a religião a responsável por criar fortes convicções sobre questões estruturais da vida. Um ateu pode ter convicções sobre a vida mais fortes que um religioso.

Dworkin considera que as pessoas não têm a tendência de considerar as crenças como religiosas a não ser que elas se refiram à existência de uma divindade. Para determinar se uma crença é religiosa, é necessário perguntar se uma crença:

[...] é suficientemente semelhante, em conteúdo, às crenças inequivocadamente religiosas. Com base nesse critério, a crença em que o valor da vida humana transcende seu valor para uma criatura de cuja vida se trata - que a vida humana é impessoal e objetivamente valiosa - é uma crença religiosa mesmo quando defendida por pessoas que não acreditam em Deus. ${ }^{286}$

As religiões tradicionais empenham-se em transformar tais crenças em argumentos inteligíveis e persuasivos para que não pareçam ser religiosos. A conclusão, para muitos, é que a vida é um valor intrínseco, o que proibiria a prática do aborto. O que se entende no direito constitucional dos EUA é que os Estados não têm direito de proteger um valor intrínseco, se com esta proteção acabam ferindo de maneira agressiva uma classe de pessoas e também quando a opinião das pessoas sobre o assunto refletir uma convicção religiosa.

A proibição do aborto deveria necessariamente existir se o feto fosse considerado uma pessoa constitucional. Partindo-se do pressuposto que o feto não tem tal caráter, então a discussão recai sobre a possibilidade de o Estado proibir o aborto para proteger o valor intrínseco da vida humana.

A decisão, em Roe v. Wade, foi tomada com base no princípio geral do Common Law da autonomia procriadora.

${ }^{286}$ DWORKIN, Op. cit., p. 217-8. 
Interessante a comparação que o autor faz acerca da possibilidade de a opinião da maioria ter que necessariamente ser imposta a todos. Caso isso fosse considerado como aceitável, poder-se-ia verificar a situação em que uma mulher fosse obrigada a abortar mesmo que isso ferisse as suas convicções pessoais.

Neste sentido, "um estado insulta com igual violência a dignidade de uma mulher grávida quando a força a fazer a escolha oposta. $\mathrm{O}$ fato de tal escolha ser aprovada por uma maioria não configura uma justificação melhor nem em um caso nem no outro."287

Salienta o autor que o Estado deve identificar os direitos e as pessoas pelos quais ele é responsável e determinar qual é a melhor forma de harmonizar tais direitos. O Estado não pode se furtar a cumprir tais obrigações pelo simples motivo de uma religião se interessar pelo assunto. Assim, invocar o argumento de Separação entre Estado e Igreja não parece, na visão de Dworkin, ser o argumento mais adequado para a solução da questão do aborto.

Os grupos religiosos defendem diversas causas humanitárias e sociais, que foram e têm sido abraçadas pelos Estados. Nada impede que Estado e Religião defendam o mesmo posicionamento.

O autor aponta uma dificuldade em determinar a extensão e a interpretação da liberdade religiosa. Um dos problemas mais frequentes ocorre quando o Estado sob o pretexto de defender objetivos seculares acaba penalizando ou restringindo uma conduta de acordo com preceitos religiosos. O Estado pode adotar políticas religiosas que aumentem o bem-estar secular da comunidade, não pode, porém, tomar parte numa questão puramente religiosa.

Se o feto fosse considerado uma pessoa constitucional, a lei que proíbe o aborto seria uma obrigação do Estado, independentemente de a proibição do aborto ser uma concepção religiosa. Mas no ordenamento constitucional, o feto não é considerado uma pessoa e se o significado da vida humana envolve questionamentos religiosos, não pode o Estado impor uma conduta aos seus cidadãos, sob pena de criar uma religião coletiva.

Nos termos da Primeira Emenda, a Suprema Corte decidiu no caso Seeger que é considerada crença religiosa não apenas aquela concepção que pressupõe a existência de um Deus. Assim, uma crença pode ser considerada religiosa ou por seu conteúdo ou pela importância que ela tem para o indivíduo.

${ }^{287}$ DWORKIN, 2009, p. 223. 
A discussão sobre o aborto tem um fundamento religioso, considerado o seu conteúdo, uma vez que passa pela valoração da vida humana. Assim, a criminalização do aborto por um Estado impede o livre exercício de religião das mulheres, uma vez que elas perdem o poder de decidir sobre o valor da vida. O Estado que proíbe o aborto acaba se comprometendo com uma visão polêmica sobre a santidade da vida.

Analisando os argumentos expostos, Dworkin aborda a questão do aborto de uma maneira interessante principalmente ao relacionar a proibição do aborto com o respeito à liberdade religiosa. De fato, a Separação entre Estado e Igreja não impede que o Estado corrobore bandeiras religiosas desde que elas sirvam para o bem-estar da sociedade.

Um Estado laico deve ter sempre a preocupação de não refutar um argumento pelo simples fato de ele ser defendido por uma religião específica. É importante lembrar que a Igreja Católica teve fundamental importância na consagração dos direitos sociais pelos ordenamentos jurídicos. Tanto que a Encíclica Rerum Novarum é citada como um dos principais documentos responsáveis pelo reconhecimento dos direitos fundamentais de $2^{\mathrm{a}}$ geração, quais seja, os direitos sociais.

Muitos dos ideais perseguidos pela Igreja Católica, assim como por demais religiões, coadunam-se com os objetivos de um Estado Laico e muitas vezes respeitam mais os direitos fundamentais que documentos seculares. A dificuldade, neste debate, está em determinar quando um argumento é puramente religioso ou apesar de religioso atende a propósitos seculares.

A questão do aborto comporta duas soluções, sendo que a sua criminalização fere diretamente a liberdade dos indivíduos, pois obriga que todos tenham a mesma concepção sobre a vida humana.

É diametralmente oposto aos princípios fundamentais de um Estado democrático impor aos seus cidadãos uma concepção com clara base religiosa. Se o Estado quer proteger a liberdade religiosa dos seus cidadãos tem que lhes conferir liberdade de escolha e não impor uma conduta. Por óbvio que o Estado não pode admitir convicções que sejam contrárias aos seus princípios fundamentais. A criminalização do aborto não é uma matéria de caráter secular, mas sim uma concepção religiosa, que portanto não pode ser adotada como finalidade estatal.

A Suprema Corte americana não demonstra preocupação em definir o início da vida como pressuposto para a possível constitucionalidade do aborto. Entendendo que nem a área médica tem um consenso sobre o início da vida, não caberia à Corte entrar 
nesta discussão. Por outro lado, adota como ponto de referência para a tomada de decisão o momento a partir do qual o feto torna-se viável fora do útero materno. Momento este que conta com comprovação científica.

Sem perquirir se existe vida desde a concepção, a Suprema Corte entende que a Constituição, ao proteger a vida, faz referência à vida extrauterina. A preocupação surge então com a saúde da mulher e com a proteção do feto que já é viável.

A não discussão do início da vida coaduna-se melhor com o princípio da laicidade do Estado, pois evita que órgãos estatais tenham que travar discussões acerca de conceitos religiosos. E mais. Impede também que importantes decisões envolvendo a Constituição de um Estado Laico estejam baseadas em concepções puramente religiosas.

A Corte Constitucional Espanhola, na Resolução 53/1985, julga a constitucionalidade de artigo do Código Penal que permite a realização do aborto nos casos de estupro, risco para a vida da mãe e de ter sido constatada séria doença mental ou física no feto até a $22^{\mathrm{a}}$ semana.

O Tribunal adota a concepção de que a vida é um processo de desenvolvimento que começa com a gestação, que gera um "terceiro" que é existencialmente diferente da mãe. O nascimento é um momento importante pois marca a passagem de uma vida protegida pela mãe para uma vida protegida pela sociedade.

A Constituição não poderia, assim, deixar de proteger a vida, enquanto direito fundamental, na fase de processo, de desenvolvimento que serviria como condição para a vida extrauterina e também para o desenvolvimento da própria vida.

A Corte entende que as exceções previstas para a punição do aborto são inconstitucionais, não pela matéria, mas sim pelo fato de a lei não ter regulado a matéria de modo a respeitar o art. 15 da Constituição (direito à vida).

A decisão da Corte é bastante interessante porque a discussão recai não sobre a possibilidade de aborto, mas sim pela constitucionalidade da legislação que introduziu excludentes ao crime de aborto. A despeito de se argumentar pela constitucionalidade material dessas excludentes, a Corte julga inconstitucional a lei por entender que a regulamentação dada foi insuficiente.

Já o Tribunal Constitucional Alemão ${ }^{288}$ tem seu primeiro julgamento sobre o aborto referente à possibilidade de realização do aborto até a $12^{\mathrm{a}}$ semana de gravidez, tal

288 ALEMANHA - Tribunal Constitucional Alemão - BVerfGE 39, 1, 1975 - Disponível em http://groups.csail.mit.edu/mac/users/rauch/germandecision/german_abortion_decision2.html - Acesso em $15 / 11 / 2011$ 
como permitido pela Reforma do Código Penal. O Tribunal Constitucional rejeita esta solução e entende que o aborto deve ser legalizado para algumas situações, que devem ser pré-definidas na lei.

Surge a discussão se a vida em desenvolvimento do feto mereceria a proteção do direito à vida. Até porque tal reconhecimento significaria também uma proteção ao direito da mãe, uma vez que a união natural do embrião com o corpo da mãe gera uma relação especial. A gravidez faz parte assim da esfera de intimidade da mulher. Contudo, se a gravidez fosse entendida como sendo somente parte da intimidade da mulher, o aborto seria uma questão de escolha pessoal sobre a qual não caberia intervenção do Tribunal.

O Tribunal entende que o nascituro é um ser humano individual, com direitos protegidos pela Constituição. $\mathrm{O}$ aborto tem, assim, uma dimensão social que necessita da regulamentação do Estado. Da mesma forma, o direito da mulher de recusar a maternidade e as consequências que dela advém também merece proteção e regulamentação do Estado. Há, assim, um conflito entre a autodeterminação da mulher, que será limitada pela gravidez, e a vida do feto, que será destruída pelo aborto. Não havendo como conciliar ambos os direitos, deverá ser dada prioridade ao direito do feto.

Caberá ao legislador determinar em quais circunstâncias deve ser permitido o fim da gravidez. Tais circunstâncias devem, contudo, representar situações em que não se espera que seja possível suportar as consequências da gravidez. Exemplo: caso em que há risco para a saúde da mulher ou em que há indicações éticas, eugênicas, sociais ou emergenciais.

A solução do Código Penal de permitir o aborto por critérios temporais e consensuais feriria o direito à vida do feto e não respeitaria, portanto, a Constituição.

O tema, porém, volta a ser discutido no Tribunal Alemão ${ }^{289}$ que entende que o Estado deve considerar em princípio o aborto como ilegítimo. Caberia ao Estado, assim, realizar a tutela dos direitos do nascituro tanto no plano normativo quanto no plano factual, combinando elementos de tutela preventiva e repressiva.

Os direitos fundamentais da mulher não têm o condão de impedir o direito à vida do nascituro. A despeito disso, poderá o legislador, de acordo com o critério da "insuportabilidade" (ou seja, a gravidez gera danos que não podem ser suportados pela

289 ALEMANHA - Tribunal Constitucional - BverfGE 88, 203, 1993 - Disponível em $\mathrm{ttp}: / / w w w . u t e x a s . e d u /$ law/academics/centers/transnational/work_new/german/case.php?id=607 - Acesso em $15 / 11 / 2011$ 
mulher), definir alguns casos em que o aborto seria permitido. Ponderando-se os bens em conflito para que o resultado seja a legalidade do aborto, o sacrifício da mulher para continuar a gravidez deve ser tão grande que será considerado insuportável para qualquer ser humano. E quem deverá realizar esta ponderação será o próprio legislador.

O Estado tem a obrigação de garantir o direito à vida pré-natal, não podendo, por isso, recusar o emprego de medidas penais. Nada impede também que sejam utilizados, pelo Estado, métodos de aconselhamento à mulher para que ela mantenha a gravidez.

Em ambas as decisões o Tribunal Constitucional foi bem explícito e enfático em garantir o direito à vida do nascituro, conferindo-lhe ampla proteção. O Tribunal foi bem incisivo em reconhecer não só o direito à vida, mas também à dignidade humana do nascituro, dando-lhe em regra preferência em relação aos direitos de personalidade da mãe.

Com o claro reconhecimento do direito à vida do nascituro, o Tribunal impõe uma obrigação ao Estado de proteger de maneira ativa o direito à vida do nascituro e não apenas de proscrever atitudes contrárias ao direito.

O Tribunal Alemão através do emprego do princípio da proporcionalidade abriu diversas possibilidades para o uso da discricionariedade pelo legislador. O legislador deve respeitar os limites impostos pelo Tribunal, mas ainda assim tem grande margem de liberdade para disciplinar a matéria. Através do critério da "insuportabilidade" é que se vislumbrou na Alemanha a legalização do aborto, bastando para tanto que se provasse a gravidez como um fato que tornaria a vida da mãe insuportável.

O Tribunal Constitucional Português ${ }^{290}$, em consulta realizada pelo Presidente da República para controle de constitucionalidade preventivo da lei que insere excludentes de ilicitude na interrupção voluntária da gravidez, também aborda a questão do aborto.

O Tribunal faz referência ao julgamento do Tribunal Alemão que julgou nula uma Lei de 1974 que atenuava e eliminava em parte a punição pelo aborto. De acordo com o Tribunal Português, o Alemão ultrapassou os limites de sua competência ao discutir os casos em que seria possível a realização do aborto. Tais discussões como não encontram solução direta na Constituição devem ser decididas com ampla margem de liberdade pelo Legislativo.

${ }^{290}$ PORTUGAL - Tribunal Constitucional Português - Processo n. 38/84 - Rel. Cons. Guilherme da Fonseca. Outras decisões no mesmo sentido: Processo 95/84; Processo 340/98; Acórdão 617/2006; 15/2010 Disponível em http://www.tribunalconstitucional.pt/tc/acordaos/ - Acesso em 15/11/2011 
Deve o Tribunal salvaguardar o "primado político do legislador", quando houver discricionariedade. Não poderia, assim, o Tribunal Constitucional se sub-rogar nesta função legislativa, sob pena de misturar o político com o jurídico.

A lei permitiria o aborto quando: a) constituísse o único meio de remover perigo de morte ou de grave e irreversível lesão para o corpo ou para a saúde física ou psíquica da mulher; b) seja indicado para remover perigo de morte ou grave e irreversível lesão para a mulher, se realizado até a $12^{\mathrm{a}}$ semana de gestação; c) o nascituro venha a sofrer de doença grave; d) a gravidez for resultado de estupro.

O Tribunal conclui que os dispositivos constitucionais acerca da inviolabilidade da vida e da integridade física englobam a vida intrauterina, o que não implicaria dizer que tais direitos devem obrigatoriamente ser alvo de tutela penal.

O nascituro tem direitos reconhecidos pelo ordenamento, ainda que sejam direitos potenciais, sob condição suspensiva.

A inviolabilidade imposta pela Constituição ao direito à vida também aplica-se a outros direitos fundamentais. Os direitos ditos invioláveis pela Constituição parecem mais fortes que os outros. A despeito disso, não há uma vinculação necessária de que estes direitos devem prevalecer em todas as situações. Há um conflito, no caso, entre os direitos da mãe e os direitos do nascituro.

Argumentou-se que a lei seria inconstitucional em razão de uma pretensa falta de precisão na descrição dos tipos penais. O Tribunal entende que não há qualquer inconstitucionalidade neste aspecto.

Voltando à possibilidade de restrição da inviolabilidade da vida humana, recorre o Tribunal à ideia de colisão de direitos fundamentais. A vida humana e a vida intrauterina não têm o mesmo conteúdo essencial, uma vez que a capacidade do nascituro é apenas restrita de modo que seria difícil dar-lhe a mesma defesa jurídica da vida humana.

É exposta a dúvida de que o princípio da proporcionalidade não estaria sendo seguido nos casos no aborto eugênico e criminológico. A despeito de a dúvida existe, parece mais razoável que o aborto possa ocorrer nas 12 primeiras semanas de gravidez. Ademais, ainda que o Tribunal tenha dúvidas quanto à constitucionalidade, deverá prevalecer a presunção de constitucionalidade das leis.

O tema do aborto reflete bastante a influência de opiniões religiosas sobre o Estado. Reiterando o defendido por Dworkin, o Estado que proíbe o aborto compromete-se com uma visão, predominantemente religiosa, acerca da santidade da vida. A maioria das 
Constituições ocidentais, dentre as quais se inclui a brasileira, não define com clareza se o feto tem direito à vida. Entendendo-se pela inexistência de um direito constitucional à vida do feto, não haveria razão jurídica a fundamentar a criminalização do aborto.

Neste sentido, a realização do aborto não estaria ferindo direito constitucional protegido, uma vez que inexistiria direito à vida do feto. Pelo contrário, a sua proibição feriria diretamente a liberdade da mulher que se veria impedida de interromper uma gravidez indesejada.

Considerar o início da vida com a concepção é um argumento puramente religioso, que não pode, portanto, embasar decisões de um Estado laico, ainda que este seja considerado como religioso tolerante. Um Estado laico não deveria impor decisões aos seus cidadãos que não tenham fundamento constitucional. A melhor forma de garantir a liberdade de consciência e crença parece ser a legalização do aborto, pois haveria plena liberdade às mulheres para que possam agir de acordo com a sua consciência. Este é o verdadeiro fundamento da tolerância, permitir que a minoria aja de acordo com a sua consciência, desde que respeitando os direitos constitucionais. A questão reside exatamente em qual seria o direito constitucional.

A teoria de que a Constituição não garante a vida intrauterina é bastante controvertida na doutrina. Alexandre de Moraes entende que:

\begin{abstract}
A Constituição, é importante ressaltar, protege a vida de forma geral, inclusive a uterina, pois a gestação gera um tertium com existência distinta da mãe, apesar de alojado em seu ventre. Esse tertium possui vida humana que iniciou-se com a gestação, no curso da qual as sucessivas transformações e evoluções biológicas vão configurando a forma final do ser humano. ${ }^{291}$
\end{abstract}

De acordo com o autor, sendo a vida uterina protegida constitucionalmente, a descriminalização poderia ocorrer, além das hipóteses previstas no Código Penal, havendo cabal comprovação médica de que a vida extrauterina seria inviável, caso do feto anencéfalo $^{292}$.

Neste mesmo sentido, encontra-se José Afonso da Silva ${ }^{293}$ que começa expondo as três posições existentes à época da constituinte sobre o direito à vida. A primeira pretendia proteger a vida desde a concepção, proibindo, assim, a realização do

\footnotetext{
${ }^{291}$ MORAES, 2011, p. 85.

${ }^{292}$ MORAES, Op. cit., p. 86.

${ }^{293}$ SILVA, 2010, p. 203.
} 
aborto. A segunda entendia que a condição de sujeito de direito seria adquirida com o nascimento com vida, de tal modo que a existência do feto seria de exclusiva responsabilidade da mulher. A terceira identificar-se-ia com a não adoção de um posicionamento final sobre o aborto, relegando a decisão ao legislador infraconstitucional.

$\mathrm{O}$ autor acredita que esta terceira opção não teria sido adotada integralmente pela Constituição, uma vez que ela aparentemente não permitiria o aborto em quaisquer casos. Segundo José Afonso, "numa época em que há muitos recursos para evitar a gravidez, parece injustificável a interrupção da vida intra-uterina que não se evitou."294

Neste ponto, autor vale-se de um argumento fático para determinar a possibilidade constitucional do aborto. É interessante notar como o debate sobre assuntos que envolvem concepções religiosas dificilmente é puramente jurídico, ainda para aqueles que defendem a exclusão total das concepções religiosas. Inegável que esse assunto envolve sempre bastante parcialidade. A dificuldade está exatamente em excluir da posição estatal concepções que, ainda que majoritárias, não tenham qualquer fundamento constitucional.

Opina também pela proteção constitucional da vida desde a concepção Maria Garcia, ${ }^{295}$ entendendo que no momento da fecundação do óvulo há vida, devendo ser protegida inclusive da mãe. “A preocupação fundamental é: se deixar-se de processar a gestação haverá vida? Com toda a certeza, sim (excluídas, aqui, as hipóteses de deformação e outras). Então, há vida humana e esta será objeto de proteção constitucional. $^{296}$

A despeito de sua opinião sobre o início da vida, a autora entende que o aborto não deve ser uma questão criminal, mas sim social e de saúde pública. Apesar de não considerar o aborto como um bem em si, ela entende que o Estado não teria o direito de tratar como uma criminosa uma mulher que decida interromper a gravidez.

Ives Gandra Martins, ${ }^{297}$ para defender o início da vida com a concepção, relembra o Pacto de São José da Costa Rica, cujo art. $4^{0}$ determina que: "toda pessoa tem direito a que se respeite a sua vida. Este direito está protegido pela lei e, em geral, a partir do momento da concepção."

\footnotetext{
${ }^{294}$ SILVA, Op. cit., p. 203.

${ }^{295}$ GARCIA, Maria. A inviolabilidade consitucional do direito à vida. A questão do aborto. Necessidade de sua descriminalização. Medidas de consenso. Cadernos de Direito Constitucional e Ciência Política. São Paulo, Revista dos Tribunais, ano 6, n. 24, julho/setembro de 1998, p. 73-83.

${ }^{296}$ GARCIA, Op. cit., p. 75.

${ }^{297}$ MARTINS, Ives Gandra da Silva. O direito à vida no Código Civil à luz da Constituição. Revista Brasileira de Direito Constitucional, São Paulo, n. 5, jan./jun. 2005, p. 18-27.
} 
Entende o autor que estão protegidos pelo direito à vida tanto o nascido quanto o nascituro, não podendo o ser humano desde a concepção ter seu direito à vida encerrado arbitrariamente. Defende o autor, a status de norma constitucional do Pacto, inclusive, com caráter de cláusula pétrea. Acrescenta ainda que o art. $2^{\circ}$ do CC coloca a salvo os direitos do nascituro.

O autor trata da decisão da Suprema Corte dos EUA que permitiu o aborto e compara os argumentos utilizados nesta decisão com os empregados pela Suprema Corte em 1857 para defender a escravidão e o direito de matar o escravo. Chega Ives Gandra a afirmar que "[...] o aborto é uma forma de pena de morte, com a utilização de métodos sangrentos e desumanos. ${ }^{298}$

A decisão sobre a criminalização da prática abortiva é um forte indicativo para demonstrar a influência religiosa que sofre um Estado. Com o brasileiro não é diferente. Ao legalizar o aborto, em casos muito restritos, demonstra o Estado a sua vocação para um Estado religioso tolerante e não para um Estado secular tolerante.

Ser um Estado com influências religiosas não é sinônimo, como já dito, de desrespeito à laicidade do Estado e aos direitos fundamentais. Deve-se, contudo, em Estados religiosos ter uma especial preocupação em adotar a posição que melhor garante a liberdade dos indivíduos, deixando para os cidadãos a livre escolha de atuação de acordo com a sua consciência ou crença.

Deve-se tentar olhar somente para o texto constitucional a fim de se determinar o grau de proteção da vida intrauterina. Entendendo-se que ela é protegida constitucionalmente, a proibição do aborto seria obrigatória. Pelo contrário, não havendo proteção constitucional, a melhor opção seria a legalização do aborto, para que as mulheres pudessem decidir de acordo com a sua concepção.

\section{III.10- Cultos religiosos e poder de polícia}

A análise da jurisprudência brasileira permite-nos verificar alguns casos concretos em que a liberdade religiosa, seja quanto à crença seja quanto ao culto, entra em conflito com outros direitos ou princípios fundamentais. Conforme será demonstrado não há uma solução fixa para quando deve prevalecer ou dever ser limitada a liberdade religiosa.

${ }^{298}$ MARTINS, Op. cit., p. 22. 
Um caso bastante frequente na jurisprudência é a restrição a cultos religiosos que desrespeitem os limites de ruído permitido pela legislação. A jurisprudência é praticamente unânime em afirmar que a prática de culto religioso que cause poluição sonora deve ser limitada para atender à legislação vigente. A liberdade religiosa deve ser preservada, mas seu exercício deve respeitar o direito da vizinhança e não causar poluição sonora, obedecendo aos limites de ruídos previstos em lei. ${ }^{299}$

Bastante esclarecedor acerca do conflito existente entre a liberdade de culto e a proteção ao meio ambiente e ao sossego público é o acórdão proferido pelo Tribunal de Justiça do Rio de Janeiro, que segue assim ementado:

Agravo de Instrumento. Ação Civil Pública. Promotoria de Tutela Coletiva. Templo religioso. Poluição sonora. Deferimento de Liminar. Recurso dirigido contra decisão que, em sede de ação civil pública, deferiu liminar para determinar à associação religiosa que se abstivesse de utilizar qualquer aparelho de amplificação sonora em suas atividades, bem como cessasse por completo suas atividades públicas, a partir das 22 horas, sob pena de multa diária para cada ato de transgressão, determinando ainda a implementação, dentro do prazo de sessenta dias, de medidas básicas de segurança indicadas pelo Corpo de Bombeiros com vistas à proteção dos freqüentadores da Igreja, sob pena de cessação de suas atividades públicas. Decisão bem fundamentada, que não se revela teratológica, contrária à lei ou à prova dos autos. Fumus boni iuris materializado nos documentos que instruem o inquérito civil, dentre os quais, dois laudos técnicos comprovando que os níveis sonoros são superiores aos permitidos, estando presente também o periculum in mora, diante dos efeitos nocivos à saúde da população vizinha causados por ruídos excessivos, além da necessidade de se prover medidas preventivas contra incêndio e pânico. Ademais, a decisão alvejada não viola o direito de liberdade de culto religioso, apenas delimitando o seu exercício com o escopo de evitar abusos em prejuízo de outros direitos também constitucionalmente garantidos, v.g., o direito à saúde, o direito ao sossego, o ordenamento urbano e o meio-ambiente saudável. Aplicação

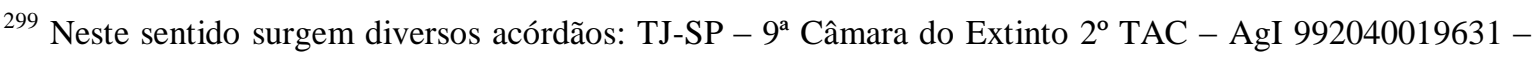
Rel. Des. Cristiano Ferreira Leite - Julgado em 16/02/2005 - DJ 28/02/2005; TJ-SP - $8^{\text {a }}$ Câmara do Quarto Grupo (Extinto 2o TAC) - Rel. Des. Kioitsi Chicuta - Julgado em 27/02/2005; TJ-SP - $25^{\text {a }}$ Câmara de Direito Privado - Apelação 992090374273 - Rel. Des. Sebastião Flavio - Julgado em 09/03/2010; TJ-RJ $10^{a}$ Câmara Cível - Apelação 2005.001.06574 - Rel. Des. José Carlos Varanda - Julgado em 13/09/2005; TJ-RJ - $7^{\text {a }}$ Câmara Cível - Apelação 2000.001.12599 - Rel. Des. Carlos C. Lavigne de Lemos - Julgado em 07/11/2000; TJ-MG - AgI 2.0000.00.279713-3/000(1) - Rel. Des. Caetano Levi Lopes - Julgado em 16/05/2000 - DJ 27/05/2000 - TJ-RS - Apelação Cível No 70019696335, Terceira Câmara Cível, Tribunal de Justiça do RS, Relator: Rogerio Gesta Leal, Julgado em 21/06/2007; TJ-RS - Apelação Cível No 598353316, Décima Oitava Câmara Cível, Tribunal de Justiça do RS, Relator: Cláudio Augusto Rosa Lopes Nunes, Julgado em 18/11/1999; TJ-SC - 3ª Câmara de Direito Público - AgI 2009.003980-2 - Rel. Des. Luiz César Medeiros - Julgado em 05/02/2010; TJ-DF - 20020020061026AGI, Relator VASQUEZ CRUXÊN, $3^{\mathrm{a}}$ Turma Cível, julgado em 13/10/2003, DJ 26/11/2003 p. 39.
} 
da Súmula 58 deste Tribunal. Conhecimento e desprovimento do Agravo. ${ }^{300}$

O entendimento esposado pelo Tribunal expõe com bastante clareza a possibilidade de limitação da liberdade religiosa em face de outros direitos fundamentais eventualmente lesados por ela. No caso debatido, o exercício da liberdade religiosa e de culto ocorreu de modo abusivo, desrespeitando outros direitos igualmente protegidos pelo ordenamento constitucional, tal como o meio ambiente saudável. Ademais, neste específico caso de colisão de direitos fundamentais, é plenamente possível compatibilizar ambos os direitos sem excluir totalmente a aplicação de um deles. É o que se verifica no acórdão proferido pelo Tribunal de Justiça da Bahia:

PROCESSUAL CIVIL - DIREITO AMBIENTAL - AÇÃO CIVIL PÚBLICA - AGRAVO DE INSTRUMENTO - POLUÍÇÃO SONORA LEGITIMIDADE DO MINISTÉRIO PÚBLICO - PARALISAÇÃO DOS CULTOS - IMPOSSIBILIDADE - DIREITOS E GARANTIAS FUNDAMENTAIS- LIBERDADE DE PRÁTICA RELIGIOSA DIREITO DE VIZINHANÇA - HARMONIZAÇÃO - AGRAVO PARCIALMENTE PROVIDO. I - A LEGITIMIDADE DO MINISTÉRIO PÚBLICO PARA O EXERCÍCIO DA DEFESA DOS DIREITOS COLETIVOS DIFUSOS É INQUESTIONÁVEL, SENDO QUE O SUPOSTO DESVIRTUAMENTO DESSA LEGITIMIDADE, NO CASO CONCRETO É ALGO AINDA A SER AFERIDO PRIMEIRAMENTE PELO JUÍZO A QUO, POR DEPENDER DE ESCLARECIMENTO DE MATÉRIA FÁTICA, COLIGÍVEL NA INSTRUÇÃO.. II - HÁ QUE SE BUSCAR A HARMONIA ENTRE CARAS LIBERDADES ELEVADAS AO STATUS CONSTITUCIONAL (LIBERDADE DE CREDO) E O BEM-ESTAR DA COMUNIDADE ENVOLVIDA (DIREITO AO MEIO AMBIENTE EQUILIBRADO), TENDO-SE EM MENTE QUE O ENTRECHOQUE DE LIBERDADES INDIVIDUAIS E COLETIVAS NÃO RARO CEDE ESPAÇO À VEICULAÇÃO DE PRECONCEITOS E À REJEIÇÃO AO QUE É DIFERENTE. III - AFASTA-SE O ESTANCAMENTO ABSOLUTO DAS ATIVIDADES RELIGIOSAS, ADMITINDO-SE A RETOMADA DOS CULTOS MEDIANTE A ADOÇÃO DE DETERMINADAS CAUTELAS (NÃO UTIIIZAÇÃ̃O DE AMPLIFICADORES), PELO MENOS ATÉ QUE ATENDIDAS AS EXIGÊNCIAS DA LEGISLAÇÃO AMBIENTAL, COM A INSTALAÇÃO DE ADEQUADO ISOLAMENTO ACÚSTICO NAS DEPENDÊNCIAS DA IGREJA. IV - AGRAVO PARCIALMENTE PROVIDO. ${ }^{301}$

\footnotetext{
${ }^{300}$ TJ-RJ - 16 $6^{\text {a }}$ Câmara Cível - AgI 0043208-88.2007.8.19.0000 - Rel. Des. Mario Robert Mannheimer Julgado em 04/03/2008

${ }^{301}$ TJ-BA - 2 Câmara Cível - AgI 1314-6/2009 - Rel. Des. Maria da Graça Osorio Pimentel Leal - Julgado em $25 / 08 / 2009$
} 
A decisão pela possibilidade de restrição da liberdade religiosa para proteger o meio ambiente e o direito da vizinhança não surge na jurisprudência apenas na análise do caso concreto, mas aparece também na apreciação de lei em tese.

Analise-se o acórdão proferido pelo TJ-SP em Ação Direta de Inconstitucionalidade impetrada contra lei municipal que excluía da proibição de perturbação do sossego público com ruídos excessivos os cultos religiosos. O Tribunal decidiu pela inconstitucionalidade da norma, primeiro por ferir o princípio da isonomia e também por entender que a liberdade de culto pode ser limitada para garantir princípios da ordem pública. ${ }^{302}$

Em julgamento de lei municipal de Sorocaba com o mesmo teor da já citada, o TJ-SP entende que a exclusão de cultos religiosos do respeito aos limites de ruídos representaria uma restrição inadmissível ao exercício do poder de polícia. ${ }^{303}$ Também nesta mesma linha de raciocínio, interessante transcrever a ementa de acórdão do TJ-DF que expõe minuciosamente as razões para não se aceitar a constitucionalidade de uma lei que exima os cultos religiosos a respeitar os limites de ruídos:

AÇÃO DIRETA DE INCONSTITUCIONALIDADE DE EXPRESSÃO. LEI DISTRITAL 4.092/08. ATIVIDADES SONORAS POTENCIALMENTE POLUIDORAS. TRATAMENTO ACÚSTICO. OBRIGATORIEDADE. EXCEÇÃO PARA TEMPLOS RELIGIOSOS. INCONSTITUCIONALIDADE.

I - O pedido de inconstitucionalidade de expressão é adequado e cabível, porquanto decotadas as palavras "exceto os de natureza religiosa", permanece hígida a vontade do legislador e a plena conformidade do artigo com o corpo da lei.

II - Aos cidadãos, a Constituição Federal garante a liberdade de crença e assegura o livre exercício dos cultos religiosos, bem como a proteção aos locais a eles destinados e às suas liturgias. III - A exceção prevista no art. 14 da Lei Distrital 4.092/08, que desobriga os templos religiosos de procederem ao isolamento acústico quando ultrapassado o limite legal de emissão de sons e ruídos, é inconstitucional. Violação aos arts. 16, inc. VI; 311 e 314, parágrafo único, inc. $\mathrm{V}$, todos da LODF, porque: a) impede a Administração de zelar e combater a poluição em quaisquer de suas formas; b) desrespeita o interesse coletivo quanto à qualidade do meio ambiente e o bem-estar dos habitantes; c) contraria lei que estabelece o dever do Estado de preservação ambiental no tocante à emissão de sons e de ruídos; d) ofende os princípios da igualdade,

\footnotetext{
302 TJ-SP - $1^{\text {a }}$ Câmara de Direito Criminal - ADI 994030077767 - Rel. Des. Passos de Freitas - Julgado em 06/01/2005

${ }^{303}$ TJ-SP - ADI 994970062716 - Julgado em 15/06/1999. No mesmo sentido: TJ-SP -Órgão Especial - ADI 994060113877 - Rel. Des. Renato Nalini - Julgado em 20/08/2008.
} 
Em sentido diverso, aparece um acórdão do TJ-MG que entende pela possibilidade de utilização de alto-falantes pela Igreja para realizar avisos de interesse da comunidade. O Tribunal fundamenta sua decisão no fato de tal prática ser tradicional dos campanários de Minas Gerais e "ainda que não autorizadas ou reconhecidas formalmente, consubstancia serviços de utilidade pública, que deve merecer o prestígio e o respeito do Estado."305

Há que se notar que sob o fundamento de tradição de uma prática admite-se o desrespeito a regras de poluição sonora e de preservação da ordem pública. Diferentemente, nos demais julgados colacionados não se tratavam de cultos tradicionalmente inseridos na cultura brasileira. É interessante pensar se o fato de um culto ser tradicional e majoritariamente aceito pela sociedade representaria um elemento diferencial para que a jurisprudência permitisse a prática de atos abusivos.

De maneira geral, a jurisprudência tem permitido tranquilamente a restrição da liberdade religiosa para proteger interesses da comunidade, que não apenas o sossego público. Pode-se também encontrar na jurisprudência decisões restringindo a liberdade religiosa para proteção do patrimônio cultural ${ }^{306}$.

Assim, passa pelo Judiciário a possibilidade de imposição de limites para a realização de pregação em praça pública. Em sede de apelação em Mandado de Segurança, julgada pelo $\mathrm{TJ}-\mathrm{RJ}^{307}$, pleiteia o impetrante o direito de pregar em praça pública sem necessidade de licença emitida pelo Município. A sentença impôs parâmetros objetivos de restrição, tais como, não utilização de equipamentos sonoros de amplificação de voz, com o intuito de impedir a perturbação do sossego público. Entendera o Juízo de $1^{\circ} \mathrm{Grau}$, em sentença corroborada pelo Tribunal, que a imposição de tais limites tornaria desnecessária a prévia autorização do Poder Público, pois tais parâmetros já impediriam por si só que a prática do culto se desse de modo abusivo.

\footnotetext{
304 TJ-GO - 20090020015645ADI, Relator VERA ANDRIGHI, Conselho Especial, julgado em 29/09/2009, DJ 21/01/2010 p. 32

${ }_{305}$ TJ-MG - MS 1.0000.00.287728 - Rel. Des. Alvim Soares - Julgado em 07/10/2002

${ }^{306}$ TJ-SP - $1^{\text {a }}$ Câmara de Direito Público - Apelação em MS 994970347800 - Rel. Des. Octaviano Santos Lobo - Julgado em 13/04/1999

${ }^{307}$ TJ-RJ - 17ª Câmara Cível - Apelação 0007712-43.2008.8.19.0006 - Rel. Des. Elton Leme - Julgado em $02 / 12 / 2009$.
} 


\section{CONCLUSÃO}

Historicamente, a religião desempenhou um papel importante para a sociedade brasileira. Tanto é assim que a primeira Constituição brasileira de 1824 consagrou a Igreja Católica como sua religião oficial, sendo a única crença com autorização para a realização de cultos externos. A todas as outras religiões era permitido tão-somente o culto doméstico. Ainda que mitigada a sua importância atualmente, os preceitos da Igreja Católica continuam pautando grande parte da opinião pública sobre assuntos relevantes não só para a sociedade, mas principalmente para o constitucionalismo.

Dentre o extenso rol de direitos fundamentais, consagrado pela Constituição Federal, insere-se a garantia da liberdade religiosa, nos termos do art. $5^{\circ}$, VI. A chamada liberdade de consciência e crença envolve, segundo a doutrina, três aspectos que devem ser igualmente respeitados e protegidos, a liberdade de crença, de culto e de organização religiosa. Pela liberdade de crença, como decorrente da liberdade de opinião, pode o indivíduo ter a crença religiosa que bem lhe aprouver, bem como não ter crença religiosa alguma. Ambas as atividades serão amplamente protegidas pelo ordenamento jurídico. Para que a liberdade de crença reste plenamente consagrada devem estar igualmente garantidos não só o direito de escolher uma religião, mas também de mudar de religião.

A liberdade de crença, contudo, é insuficiente para garantir em sua totalidade a liberdade religiosa. De nada adianta poder acreditar em qualquer religião, se não houver o direito de agir conforme a crença escolhida pelo indivíduo. Neste ponto entra a liberdade de culto, que em um Estado Constitucional deve ser protegida com a mesma intensidade que a liberdade de crença. Por ela, pode o cidadão, além de praticar publicamente o culto de sua religião, pautar as suas atitudes de acordo com os preceitos religiosos em que acredita.

Pelo fato de o exercício da liberdade de culto ser externo e público, podem ser vislumbradas as primeiras situações autorizadoras de uma eventual restrição da liberdade religiosa. Como todo direito fundamental, a liberdade de culto é considerada relativa, sendo passível de restrição quando em conflito com outro direito fundamental. Aqui se terá a clássica situação de colisão de direitos fundamentais, em que o exercício concomitante de dois direitos fundamentais gera uma situação em que somente um pode prevalecer no caso concreto. Caso o exercício de um culto venha a ameaçar o exercício de 
outro direito fundamental ou ainda de um princípio constitucional, a análise criteriosa do caso concreto pode indicar a proibição esporádica de um culto religioso.

É sempre importante lembrar que a restrição de um direito fundamental se devidamente fundamentada e com o fim de garantir efetividade a outro preceito constitucional igualmente consagrado, não significa em nada uma agressão à Constituição e muito menos ao direito que sofreu a restrição. Destarte, plenamente admissível a imposição de limites ou mesmo a proibição de um culto religioso, se tal medida for necessária, adequada e proporcional para garantir outro direito fundamental.

Para tornar ainda a liberdade religiosa completa, é necessário que seja garantida a liberdade de organização religiosa. Não deve o Estado proibir a criação de quaisquer tipos de novas religiões, salvo se elas forem constituídas com propósitos ilícitos. Não cabe ao Estado julgar ou analisar o conteúdo pregado por qualquer religião, pois o assunto religioso lhe é estranho, dada a laicidade imposta pela Constituição. Havendo, dentro dos fundamentos da religião, finalidades ilícitas, sempre estará autorizado o Estado a intervir, qualquer seja o direito envolvido, ainda que fundamental

O exercício pleno da liberdade religiosa depende intrinsecamente do papel do Estado frente ao fenômeno religioso. Vários são os modelos e as classificações de relação entre Estado e Igreja. Pelo modelo da confusão, o Estado é visto como teocrático, já que religião e Estado confundem-se em um só. Mais atenuado é o modelo da união, em que o Estado e Religião são poderes separados, mas há influência direta da religião sobre o poder político. Por fim, o da Separação, em que o fenômeno religioso passa a ser assunto privado, totalmente estranho ao comando estatal.

Este último foi adotado pela Constituição como sendo, na sua visão, o mais adequado para atingir as suas finalidades e para garantir a plenitude da liberdade religiosa. Assim, no art, 19, I, o texto constitucional consagrou o Estado Laico, impedindo que haja qualquer influência, negativa ou positiva, do Estado sobre as religiões. Em sentido contrário, também não deveriam preceitos religiosos influenciar decisões estatais, uma vez que não tem o Estado um religião oficial.

Em razão de episódios históricos, como as Inquisições Portuguesa e Espanhola, em que um Estado religioso foi responsável pela criação de um ambiente de profunda intolerância religiosa e de perseguição àqueles que desafiavam a religião oficial, passou-se a ter como voz corrente que o Estado Laico seria o único apto a respeitar a liberdade de consciência. 
Esta é uma ideia que precisa ser desmitificada. É perfeitamente possível que um Estado que tenha uma religião oficial, ou ainda que sofra influências diretas de uma religião, garanta e respeite a tolerância religiosa. A laicidade do Estado não é garantia de respeito à liberdade religiosa, podendo inclusive gerar o efeito contrário. Ao invés de fomentar a tolerância religiosa, pode acabar incentivando a hostilidade às religiões. Um Estado laico não deve ter a pretensão de retirar a religião da vida de seus cidadãos, mas tão-somente de retirá-la da condução do Estado.

Não são raros os Estados que tradicionalmente defenderam a laicidade e hoje refletem posições hostis às religiões. Tal é o caso da proibição de porte de símbolos religiosos ostensivos em escolas públicas pela França, país historicamente defensor das liberdades públicas e de um modelo de Separação rígida entre Estado e Igreja. O que se verifica na lei francesa é a tentativa de impor o dever de neutralidade que pertence exclusivamente ao Estado a seus cidadãos, a quem deveria ser garantida a plena liberdade de expressão religiosa, qualquer que seja ela e desde que não represente uma agressão à ordem pública.

O Estado brasileiro adotou, como modelo, a separação entre Estado e Igreja. Como decorrência da garantia da liberdade religiosa de um lado e da laicidade do Estado de outro, a nossa Constituição garante institutos clássicos, como a escusa de consciência e a assistência religiosa a internados em estabelecimentos coletivos, que no quadro constitucional atual não geram muitos questionamentos.

Analisando de maneira mais profunda o modelo adotado pelo Estado brasileiro, começam a surgir algumas dúvidas. Seria esta separação verdadeiramente rígida? Ou sofreria o Estado brasileiro influência expressiva de uma religião?

Não é demais salientar que eventual reconhecimento de influência religiosa sobre o Estado não teria qualquer sentido pejorativo para a democracia brasileira, pois, como já dito, a laicidade rígida não é sinônimo de tolerância religiosa, nem de respeito aos direitos fundamentais.

Aqui é salutar lembrar a diferenciação entre Estado religioso tolerante e Estado secular tolerante, trazida por Dworkin.

Um estado religioso, ainda que não tenha uma religião oficial, defende a religião como algo importante para o bem da sociedade e das pessoas. Ele garante respeito a todos os tipos de crenças, inclusive aos não crentes, contudo, não se preocupa em anunciar como política oficial do Estado que aqueles que não têm religião encontram-se 
profundamente equivocados. Pelo contrário, para um Estado ser considerado secular não basta que ele seja tolerante com todas as religiões. Ele não pode apresentar qualquer tipo de influência religiosa, seja em pronunciamentos oficiais, seja em qualquer tipo de manifestação que vincule a figura do Estado com a religião.

Em qual dos dois modelos se enquadraria o Estado brasileiro?

O preâmbulo da Constituição Federal ao invocar a proteção de Deus dá um indício contundente de que coloca a religião em uma posição de relevância para a sociedade. A permanência de símbolos religiosos, mais especificamente crucifixos, em prédios públicos confirma a ideia de que, não só a crença em Deus, mas na Igreja Católica tem posição de destaque para o nosso Estado.

Tal influência, entretanto, é raramente reconhecida de maneira oficial, provavelmente em razão do conceito de que a influência religiosa significaria automaticamente o extermínio da tolerância. Para não reconhecer a importância especial da Igreja Católica, acaba-se fundamentando a permanência do crucifixo em uma hipotética importância histórica do símbolo, destituída de significado religioso.

Os fatores descritos começam a indicar que o Estado brasileiro aproximarse-ia mais de um Estado religioso, do que de um secular.

Importante diferença entre Estado religioso e secular é a visão que ambos têm da liberdade religiosa. Ainda que por ambos consagrada, o seu âmbito de proteção é reduzido no Estado religioso. Neste, o fundamento da liberdade seria a crença especial num poder divino, criando obstáculos à discussão livre de temas fundamentais sobre a vida, tais como o aborto e a pesquisa com células-tronco, fazendo com que tais debates partissem de pressupostos religiosos.

O Estado tolerante, pelo contrário, não teria posição consolidada sobre qualquer tipo de questão fundamental, tal como o início da vida, tornando mais livre o campo de decisão sobre os referidos temas. Ampliaria substancialmente o espectro da liberdade religiosa.

A discussão sobre o aborto, entre nós, ilustra perfeitamente a situação explanada. A descriminalização do aborto encontra forte resistência em grande parte da sociedade, por considerar como verdade inabalável que o aborto significaria um atentado inadmissível à vida humana. Não seria a ideia de que a vida tem início com a concepção um conceito puramente religioso? Que a maioria da sociedade seja contrária ao aborto em razão de crenças religiosas não se pode opor qualquer objeção. A adoção deste pressuposto 
pelo Estado, contudo, denuncia que ele molda a liberdade religiosa dos indivíduos numa perspectiva estreita, já que ele mesmo fornece a resposta, que não é científica, sobre o início da vida.

Tal afirmação pode inclusive ser confirmada tomando por base a discussão que está aberta hoje no Supremo Tribunal Federal sobre a possibilidade de aborto de feto portador de anencefalia. Mesmo, neste caso, em que não há potencialidade de vida extrauterina, o assunto não tem solução clara nem pacífica.

Um Estado puramente secular jamais adotaria uma solução pré-determinada sobre o momento do início da vida, como fazem os Estados que, por exemplo, proíbem o aborto. Na visão de um Estado secular, a decisão sobre o início da vida e a possibilidade de realização de um aborto caberia exclusivamente a cada cidadão, que tomaria a decisão de acordo com as suas concepções religiosas ou filosóficas. Por sua vez, um Estado religioso toma como base um preceito religioso, do início da vida com a concepção, e por ele pauta a o seu quadro legislativo.

Ainda que um Estado religioso possa garantir plenamente a tolerância religiosa, ele acaba inevitavelmente reduzindo o âmbito de atuação da liberdade religiosa, sem, é preciso ressaltar, aniquilá-la.

$\mathrm{Na}$ mesma linha de raciocínio, podem ser consideradas as decisões majoritariamente vistas na jurisprudência brasileira que impedem a recusa de transfusões de sangue por Testemunhas de Jeová. Neste caso, porém, vislumbra-se um possível exagero na posição estatal. Ao impedir que determinadas pessoas ajam de acordo com a sua crença, o Estado acaba dando passos rumo à intolerância religiosa.

Aqui se torna indiferente a razão da intervenção estatal, que pode ser tanto por motivos laicos radicais de impedir que uma crença religiosa defina a morte de uma pessoa, quanto por motivos ligados a uma religião específica que desaprovaria o comportamento de integrantes de outra religião. Seja o Estado religioso ou secular sua preocupação deve sempre ser em manter incólume o respeito às demais religiões, não impedindo a livre manifestação da crença pelos seus fiéis.

Muitos são os desafios que um Estado enfrenta ao lidar com o debate religioso, que é sempre apaixonado, qualquer que seja a fundamentação, religiosa ou laica. Restam muitas questões ainda sem solução na nossa ordem constitucional, como qual seria o modo mais adequado de implantar o ensino religioso nas escolas públicas sem ferir os princípios constitucionais. 
Analisando-se a posição do Estado brasileiro que dizem respeito a temas religiosos, pode-se concluir que a laicidade do Estado é fundamentada numa Separação atenuada entre Estado e Igreja. Estaria, assim, o Brasil muito mais próximo de um Estado religioso do que de um Estado secular.

Tal conclusão não faz com que recaia sobre o Estado brasileiro qualquer pecha de antidemocrático e agressor de direitos fundamentais. É plenamente possível que um Estado seja religioso e ao mesmo tempo tolerante. Por seu turno, é inevitável reconhecer que a existência de uma influência religiosa sobre o Estado diminui o âmbito de proteção da liberdade religiosa dos seus cidadãos, uma vez que vincula a decisão sobre questões fundamentais a um pressuposto básico religioso.

Um Estado religioso pode ser tolerante, mas sob a perspectiva da amplitude da liberdade religiosa, um Estado secular ser-lhe-ia mais benéfico. 


\section{BIBLIOGRAFIA}

ALEXY, Robert. Teoría de los derechos fundamentales. Madrid: Centro de Estudios Constitucionales, 2001.

ANDRADE, José Carlos Vieira de. Os direitos fundamentais na Constituição Portuguesa de 1976. Coimbra: Almedina, 1998.

BARRETO, Maria Luiza Whately. Exercício da liberdade religiosa. Cadernos de Direito Constitucional e Ciência Política, n. 14, 1996.

BARROSO, Luís Roberto. Interpretação e aplicação da Constituição. 3 ed. São Paulo: Saraiva, 1999.

BASTOS, Celso Ribeiro. Curso de direito constitucional. 22 ed. São Paulo: Malheiros, 2010.

BASTOS, Celso Ribeiro. Direito de recusa de pacientes submetidos a tratamento terapêutico às transfusões de sangue, por razões científicas e convicções religiosas. Revista dos Tribunais São Paulo, v.90, n.787, jul. 2001, p.493-507.

BASTOS, Celso Ribeiro. Hermenêutica e interpretação constitucional. 2 ed. São Paulo: Celso Bastos, 1999.

BASTOS, Celso Ribeiro; MARTINS, Ives Gandra. Comentários à Constituição do Brasil. 8. ed., São Paulo: Saraiva, 1988.

BELLANGER, François. Sectes, religions et dérives sectaires in L'État face aux derives sectaires: actes du colloque du 25 novembre 1999. Genève, Helbing \& Lechtenhann: Faculte de droit de Genève, 2000

BONAVIDES, Paulo. Curso de Direito Constitucional. 11 ed, São Paulo: Malheiros, 2001 .

BORJA, Célio. O Estatuto constitucional da religião e da beneficência. Revista da EMERJ. Rio de Janeiro, v. 6, n.23, 2003, p. 96-112.

BROWNSTEIN, Alan, La proteccion otorgada por la Constitucion de los Estados Unidos a las crencias religiosas y a los grupos religiosos. Revista de la Facultad de Derecho de Mexico. Mexico, v. 41, n. 178-179-180, 1991, p. 15-7. 
BUENO, José Antonio Pimenta. Direito público brazileiro. Rio de Janeiro: Typographia Imp. e Const. de J. Villeneuve e C., 1857.

BURDEAU, George. Les libertés publiques. 4 ed. Paris: Librairie Générale de Droit et de Jurisprudence, 1972.

CANAMARES ARRIBAS, Santiago. El empleo de simbología religiosa en Espana. Boletin Mexicano de Derecho Comparado, n. 116, v. 39, maio-agosto 2006, pp. 318330 .

CANOTILHO, J. J. Gomes. Direito constitucional. 6. ed, Coimbra: Almedina, 1993.

CANOTILHO, José Joaquim Gomes. Direito Constitucional e Teoria da Constituição. 3 ed., Coimbra: Almedina, 1998.

CHAVES, Antônio. A ordem religiosa "testemunhas de Jeová" não admite trnsfusões de sangue. Como ficam as operações com crianças em perigo de vida? Revista Trimestral de Jurisprudência dos Estados, ano 20, v. 147, São Paulo, abril, 1996.

COMPARATO, Fábio Konder. A afirmação histórica dos direitos humanos. 3. ed., São Paulo: Saraiva, 2003.

CRETELLA JR., José. Comentários à constituição brasileira de 1988. 3 ed., Rio de Janeiro: Forense, 1997.

CRETELLA JR., José. Liberdades Públicas. 4 ed. São Paulo: José Bushatsky, 1974.

COLLIARD, Claude Albert. Libertés publiques. 4 ed. Paris: Dalloz, 1979.

DELSENNE, Ludivine, De la difficile adaptation du principe républicain de laïcité à L'évolution socio-culturelle française. Revue du Droit Public et de la Science Politique en France et à L'Etranger Paris. mars/avr. n.2, 2005

DÓRIA, A. de Sampaio. Os direitos do homem. 3. ed. São Paulo: Companhia das Letras, 1942.

DRAGO, Roland. Laicité, neutralité, liberté? Archives de Philosophie du Droit, Paris, n. 38, 1993.

DUFFAR, Jean. Les nouveaux mouvements religieux et le droit international. Revue du Droit Public et Science Politique en France et à l'Etranger, Paris. n.4. p.1037-56. 1998. 
DWORKIN, Ronald. Domínio da vida - aborto, eutanásia e liberdades individuais. São Paulo: Martins Fontes, 2009.

DWORKIN, Ronald. Is democracy possible here? Principles for a new political debate. Princeton: Princeton University Press, 2006.

DWORKIN, Ronald. Taking rights seriously. Massachusetts: Harvard University Press Cambridge, 1980.

ESPÍNDOLA, Ruy Samuel. Conceito de princípios constitucionais. São Paulo: Revista dos Tribunais, 1999.

FERRAZ, Anna Cândida da Cunha. O ensino religioso nas escolas públicas: exegese do $\S$ $1^{\text {o }}$ do art. 210 da CF. Cadernos de Direito Constitucional e Ciência Política, São Paulo. v.5. n.20. p.19-47. jul./set. 1997.

FERREIRA, Pinto. Direito Constitucional Moderno. 5 ed. São Paulo: Revista dos Tribunais, 1971. Tomo II.

FERREIRA, Wolgran Junqueira. Direitos e garantias individuais - comentários ao artigo $5^{\circ}$ da CF/88. São Paulo: Edipro, 1997.

FERREIRA FILHO, Manoel Gonçalves. Comentários à Constituição brasileira de 1988. 3.ed., São Paulo, Saraiva, 2000.

FERREIRA FILHO, Manoel Gonçalves. Direitos humanos fundamentais. São Paulo: Saraiva, 2004.

FERREIRA FILHO, Manoel Gonçalves. Liberdades públicas (parte geral) Manoel Gonçalves Ferreira Filho, Ada Pellegrini Grinover, Anna Cândida da Cunha Ferraz. São Paulo: Saraiva, 1978.

FERREIRA FILHO, Manoel Gonçalves. Religião, Estado e Direito. Revista Direito Mackenzie, São Paulo, v. 3, n.2, p.81-9, 2002.

FLAUSS, Jean-François. Laïcité et Convention européenne des droits de l'homme. Revue Du Droit Public de La Science Politique en France et à l'Étranger. Paris, LGDJ, n. 2, 2004.

FRANCO, Afonso Arinos de Melo. Curso de direito constitucional brasileiro. 4 ed. São Paulo: Forense, 1958.

GARCIA, Maria. A inviolabilidade consitucional do direito à vida. A questão do aborto. Necessidade de sua descriminalização. Medidas de consenso. Cadernos de Direito Constitucional e Ciência Política. São Paulo, Revista dos Tribunais, ano 6, n. 24, julho/setembro de 1998. 
GOY, Raymond. La garantie européenne de la liberte de religion. L'article 9 de la Convention de Rome. Archives de Philosophie du Droit, Paris, n. 38, 1993, p. 169-184.

HAYEK, Friedrich August Von. Os fundamentos da liberdade. Brasília: Unb, 1983, Tradução de Anna Maria Capovilla e José Ítalo Stelle.

JORDÃO, Carvalho. As confissões religiosas e a Constituição. Scientia Ivridica: revista de direito comparado português e brasileiro,n. 45, jan./jun. 1996.

KOUBI, Geneviève. Vers une déconstruction du príncipe de laïcité? Revue Du Droit Public de La Science Politique en France et à l'Étranger. Paris, LGDJ, n. 2, 2004, p. 327.

LABRADA RUBIO, Valle. Introducción a la teoría de los derechos humanos. Madrid: Civitas, 1998.

LANARES, Pierre. Liberte religieuse dans les conventions internationales et dans le droit public general; these presentee a l'universite. Roanne: Horvath, 1964.

LAYCOCK, Douglas. Theology scholarships, the pledge of allegiance and religious liberty: avoiding the extremes but missing the liberty. Harvard Law Review, Cambridge, v.118, n.1, 2004.

LECHLITER, Michael E. The free exercise of religion and public schools: the implications of hybrid rights on the religious upbringing of children. Michigan Law Review, August 2005. vol. 103, n. 8 .

LE TOURNEAU, Dominique. El velo islâmico y la neutralidad de la escuela pública em Francia in Boletin Mexicano de Derecho Comparado. Universidad Nacional Autônoma de México, ano XXX, n. 89, mayo-agosto de 1997, p. 623-632.

LOPEZ CASTILLO, Antonio. Acerca del derecho de libertad religiosa. Revista Española de Derecho Constitucional, Madrid. v.19. n.56, mar./ago. 1999, p. 88-9.

LÓPEZ CASTILLO, Antonio. Libertad de consciencia y de religión. Revista Española de Derecho Constitucional, Madrid. v.21. n.63. p.11-42. sept./dic. 2001, São Paulo. v.3. n.2. p.81-9. 2002.

LOZANO, Jose Maria. Tratado de los derechos del hombre. 2. ed. México: Editorial Porrúa S.A., 1972.

MACHADO, Jonatas Eduardo Mendes, A Constituição e os movimentos religiosos minoritários. Boletim da Faculdade de Direito da Universidade de Coimbra, Coimbra. n.72. 1996, p. 213-5. 
MACHADO, Jónatas Eduardo Mendes. Liberdade religiosa numa comunidade constitucional inclusiva: dos direitos da verdade aos direitos dos cidadãos. Coimbra: Coimbra Editora, 1996.

MARTINS, Ives Gandra da Silva. O direito à vida no Código Civil à luz da Constituição. Revista Brasileira de Direito Constitucional, São Paulo, n. 5, jan./jun. 2005.

MARTINS, Ives Gandra da Silva. Educação religiosa nas escolas públicas - inteligência do art. 210 da Constituição Federal - opinião legal. Revista de Direito Civil, Imobiliário, Agrário e Empresarial, n. 75, 1996.

MATTOS, Jadir de; STUMER, Kátia Rejane; COSTA, Joselaine da. Responsabilidade penal do médico nos casos de transfusão de sangue, em menor de idade em, iminente risco de vida, cujos pais são adeptos da seita Testemunhas de Jeová. Revista de Direito Sanitário. São Paulo. v.6, n.1/3, 2005, p.132-50.

MENDES, Gilmar Ferreira. Direitos fundamentais e controle de constitucionalidade estudos de direito constitucional. 3 ed. São Paulo: Saraiva, 2004.

MENDONÇA, Antonio Gouvêa. República e pluralidade religiosa no Brasil. Revista USP, São Paulo, v. 59, 2003.

MIRANDA, Jorge. Manual de Direito Constitucional. 2 ed. Coimbra: Coimbra, 1983.

MIRANDA, Pontes. Democracia, liberdade, igualdade (os três caminhos). 2 ed. São Paulo: Saraiva, 1979.

MORAES, Alexandre de. Direito constitucional. 25 ed. São Paulo: Atlas, 2010.

MORAES, Alexandre de. Direitos humanos fundamentais - Teoria geral Comentários aos arts. $1^{\circ}$ a $5^{\circ}$ da Constituição da República Federativa do Brasil. $9^{a}$ ed. São Paulo: Atlas, 2011.

NERY JUNIOR, Nelson. Escolha esclarecida de tratamento medico por pacientes Testemunhas de Jeová como exercício harmônico de direitos fundamentais. Parecer. São Paulo, 2009.

NEUTRAL rules of general applicability: incidental burdens on religion, speech and property. Harvard Law Review, Cambridge, v.115, n.6, apr. 2002, p. 1721-2.

OLIVITO, Elisa. Laicità e simboli religiosi nella sfera pubblica esperienze a confronto. Diritto Pubblico, Bologna, v.10, n.2, mag./ago. 2004, p. 549-550 
PASCAL, Jan. La laicité à l'école: le droit national contre le droit local. La loi plutôt que La négociation. Question de valeurs. Revue Du Droit Public de La Science Politique en France et à l'Étranger. Paris, LGDJ, n. 2, 2004.

PERELMAN, Ch. [Org.]. Les antinomies em droit. Bruxelas: Émile Bruylant, 1965.

PIERRE CAPS, Stephane. Les nouveaux cultes et le droit public. Revue du Droit Public et de la Science Politique en France et à l'Etranger, Paris, n. 4, jul./ago. 1990

PINHEIRO, Maria Cláudia Bucchianeri, A separação Estado-igreja e a tutela dos direitos fundamentais de liberdade religiosa no Brasil. Dissertação [Mestrado]. Faculdade de Direito da USP, São Paulo, 2007.

PIOVESAN, Flávia. Direitos humanos e o direito constitucional internacional. São Paulo: Max Limonad, 1996.

RIVERO, Jean. Les libertés publiques. Paris: Presses universitaires de France, 1997.

RIVERO, Jean; MOUTOUH, Hugues. Liberdades Públicas. São Paulo: Martins Fontes, 2006

PRÉLOT, Pierre-Henri. La liberté de l'enseignement dans la séparation des églises et de l'État. Revue du Droit Public et de la Science Politique en France et a l'Etranger, Paris, n. 3, mai./jun. 2006, p. 759-91

RIMOLI, Francesco. Estado laico e integración en la perspectiva constitucional. Isonomía: Revista de Teoría y Filosofia del Derecho, Mexico, n. 24, abr. 2006, p. 51-73.

ROBERT, Jacques. Cacophonie. Revue Du Droit Public de La Science Politique en France et à l'Étranger. Paris, LGDJ, n. 2, 2004.

ROBERT, Jacques. Droits de T'homme et libertés fondamentales. 5 ed. Paris: Montchrestein, 1993.

SCHERKERKEWITZ, Iso Chaitz, O direito de religião no Brasil. Revista Trimestral de Jurisprudência dos Estados, São Paulo, v.20, n.146, mar. 1996.

SILVA, José Afonso da. Curso de direito constitucional positivo. 33 ed. São Paulo: Malheiros, 2010. 
SILVA NETO, Manoel Jorge. A Suprema Corte norte-americana e a liberdade religiosa. Revista Brasileira de Direito Público, Belo Horizonte, v. 5, n. 19, out./dez., 2007, p. 110.

SORIANO, Aldir Guedes. Liberdade religiosa no direito constitucional e internacional. São Paulo: Juarez de Oliveira, 2002.

SORIANO, Rámon. Las libertades públicas. Madrid: Tecnos, 1990.

VILLACA, Álvaro Villaça. Autonomia do paciente e direito de escolha de tratamento médico sem transfusão de sangue mediante os atuais preceitos civis e constitucionais brasileiros. Parecer. São Paulo: 2010. 